Portland State University

PDXScholar

Spring 7-5-2016

\title{
Assessment of a Mycorrhizal Fungi Application to Treat Stormwater in an Urban Bioswale
}

Alaina Diane Melville

Portland State University

Follow this and additional works at: https://pdxscholar.library.pdx.edu/open_access_etds

Part of the Fungi Commons, Geography Commons, and the Water Resource Management Commons Let us know how access to this document benefits you.

\section{Recommended Citation}

Melville, Alaina Diane, "Assessment of a Mycorrhizal Fungi Application to Treat Stormwater in an Urban Bioswale" (2016). Dissertations and Theses. Paper 3024.

https://doi.org/10.15760/etd.3019

This Thesis is brought to you for free and open access. It has been accepted for inclusion in Dissertations and Theses by an authorized administrator of PDXScholar. Please contact us if we can make this document more accessible: pdxscholar@pdx.edu. 
Assessment of a Mycorrhizal Fungi Application to

Treat Stormwater in an Urban Bioswale

by

Alaina Diane Melville

A thesis submitted in partial fulfillment of the requirements for the degree of

Master of Science

in

Geography

Thesis Committee:

Martin Lafrenz, Chair

Andrés Holz

Jennifer Morse

Portland State University

2016 
(C) 2016 Alaina Diane Melville 


\begin{abstract}
This study assessed the effect of an application of mycorrhizal fungi to stormwater filter media on urban bioswale soil and stormwater in an infiltrationbased bioswale aged 20 years with established vegetation. The study tested the use of commercially available general purpose biotic soil blend PermaMatrix ${ }^{\circledR}$ BSP Foundation as a treatment to enhance Earthlite ${ }^{\text {tm }}$ stormwater filter media amelioration of zinc, copper, and phosphorus in an ecologically engineered structure designed to collect and infiltrate urban stormwater runoff before it entered the nearby Willamette River.

These results show that the application of PermaMatrix ${ }^{\circledR}$ BSP Foundation biotic soil amendment to Earthlite ${ }^{\mathrm{Tw}}$ stormwater filter media contributed to the reduction of extractable zinc in bioswale soil (-24\% and $-26 \%)$, as compared to the control, which received a treatment of Earthlite ${ }^{\mathrm{Tw}}$ stormwater filter media only, and experienced an increase in extractable zinc levels (23\% and 39\%). The results presented also show evidence that after establishment mycorrhizal treatment demonstrated lowered levels of phosphorus in bioswale soil (-41\%) and stormwater (-100\%), in contrast to the control, which had increased phosphorus levels. The treatment contributed to reductions between $67 \%$ and $100 \%$ in every metric detected in stormwater after an establishment period of 17 weeks, while the bioswale with no mycorrhizal treatment had increases between $50 \%$ and $117 \%$. Treatment also appeared to enhance the reduction of ammonium and nitrates, while contributing to a greater increase in soil $\mathrm{pH}$.
\end{abstract}




\section{Acknowledgements}

Many thanks to those who offered the support and assistance which helped make the completion of this thesis possible.

Thank you to Portland Community College for hosting the study site and to Jack Lussier, John Gwaltney-Beaumont, and Luke McKinnon for facilitating the process. Thank you to Portland Community College professors Christina Friedle, April Fong, and Linda Fergusson-Kolmes for inviting me into your classrooms.

Many thanks to my thesis committee, Dr. Martin Lafrenz, Dr. Andrés Holz, and Dr. Jennifer Morse for your feedback and guidance. I would also like to express appreciation to all the professors, staff, and students in the Portland State University community and the Geography Department who have joined me on this journey.

I want to express appreciation to Dr. Joseph Maser, my undergraduate advisor, and the Environmental Science and Management Department at Portland State University.

Special thanks to Ryan Holman, Sunmark Environmental, and PermaMatrix ${ }^{\circledR}$ Inc. for joining the study and for working to provide products that improve soil health, and filter polluted stormwater.

Thank you to my family and friends for all your support, love, and the lack thereof, the combination somehow worked.

Most of all I want to acknowledge my partner Nathan Henry. Thank you for your edits, insights, patience, and love. This one's for you. 


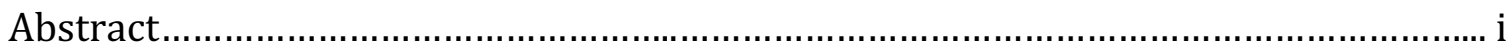

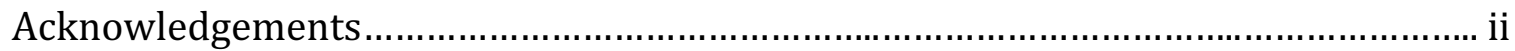

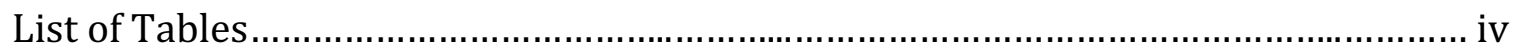

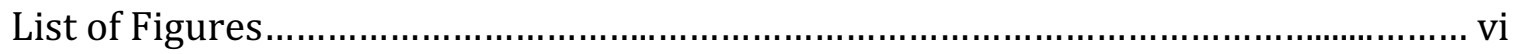

\section{Chapter 1}

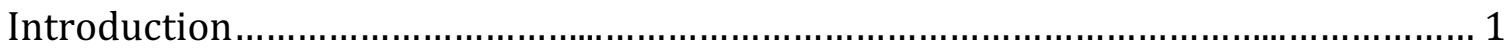

Chapter 2

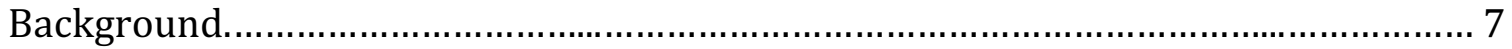

Chapter 3

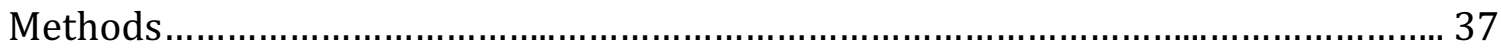

Chapter 4

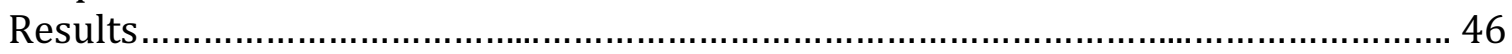

Chapter 5

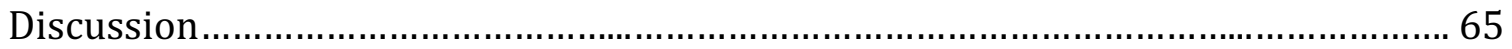

Chapter 6

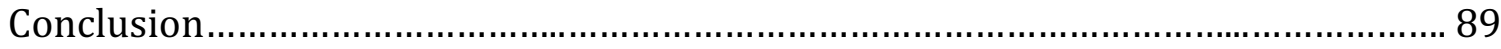

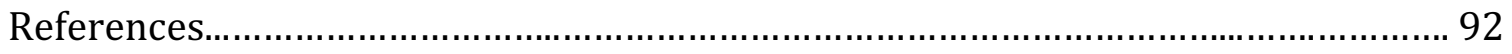

Appendices

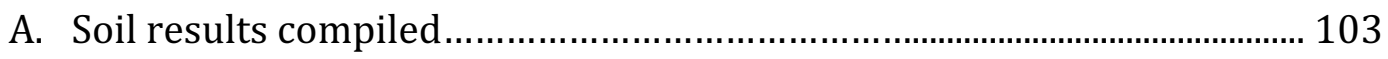

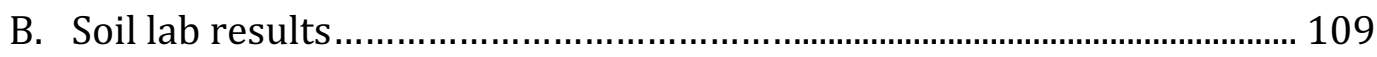

C. Stormwater lab results.......................................................................... 129 


\section{List of Tables}

Table 1: PermaMatrix ${ }^{\circledR}$ BSP Foundation ingredients........................................... 21

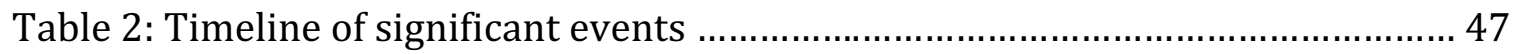

Table 3: Tracer dye study results................................................................ 48

Table 4: Results for field moisture, organic matter, and texture.............................. 49

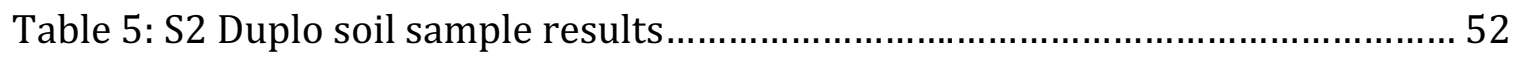

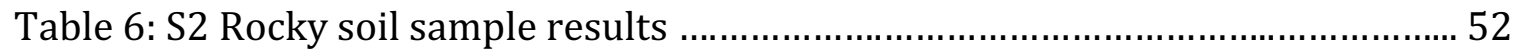

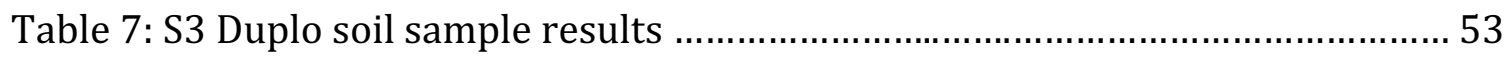

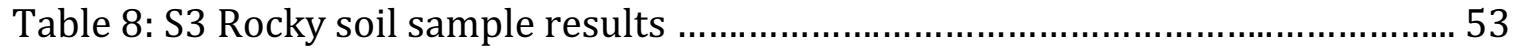

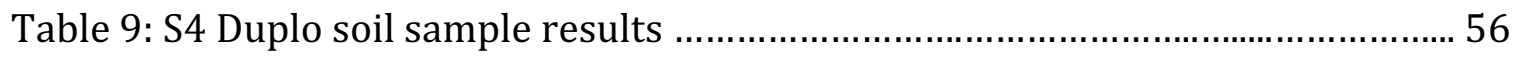

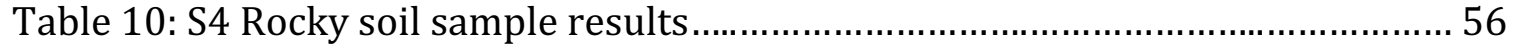

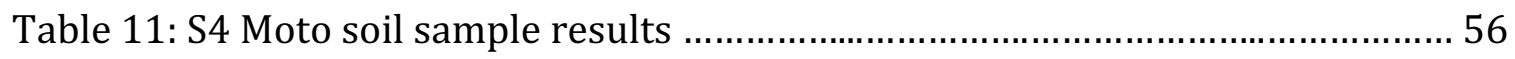

Table 12: Duplo soil sample results compared over time ..................................... 57

Table 13: Rocky soil sample results compared over time................................... 57

Table 14: Duplo percent change before and after treatment................................ 58

Table 15: Rocky percent change before and after treatment.............................. 58

Table 16: Duplo and Rocky percent change compared....................................... 59

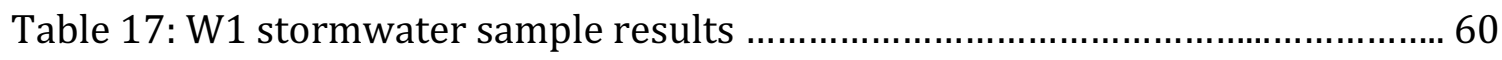

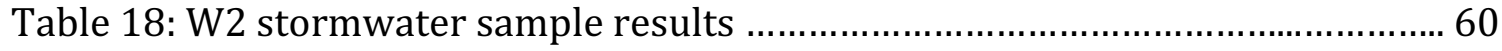

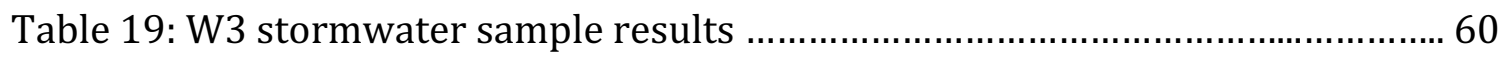

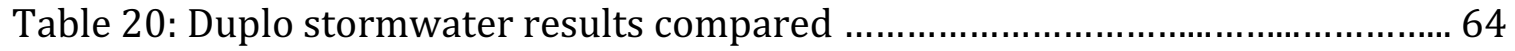

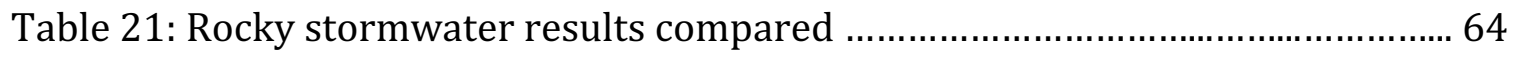




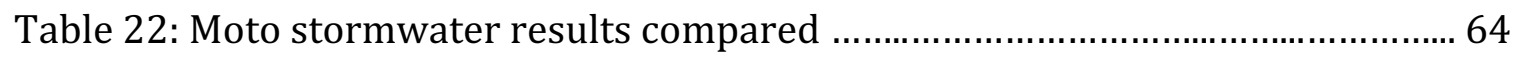

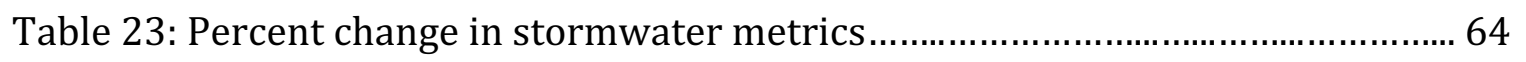




\section{List of Figures}

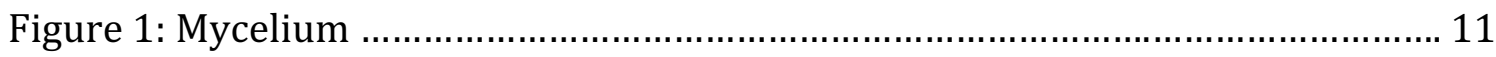

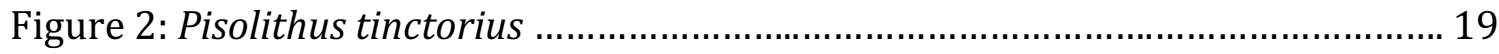

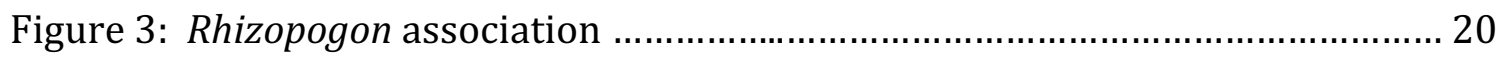

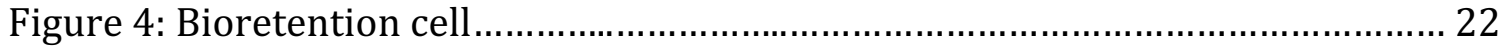

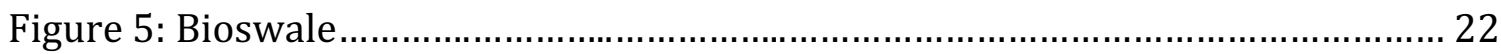

Figure 6: Green Street map showing study area ……………………………..... 28

Figure 7: Standard bioswale design................................................................. 30

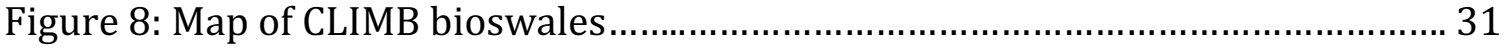

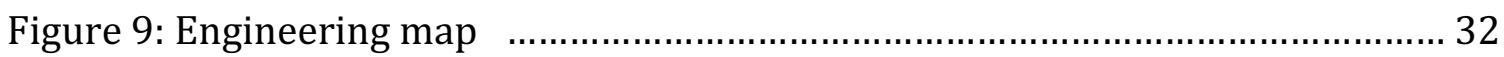

Figure 10: Map of CLIMB and surrounding area....................................................... 33

Figure 11: Photo of Duplo In stormwater pool....................................................... 33

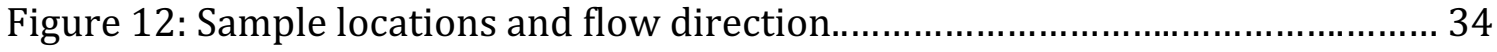

Figure 13: Photo of Rocky Out stormwater pool.................................................... 35

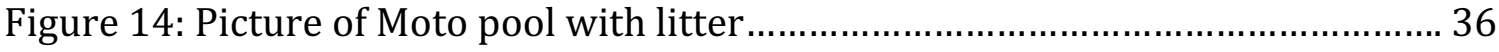

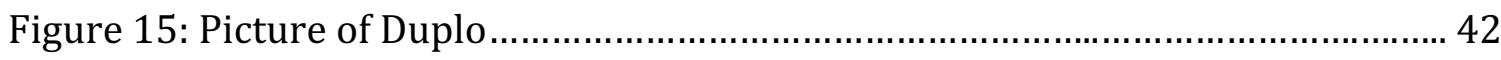

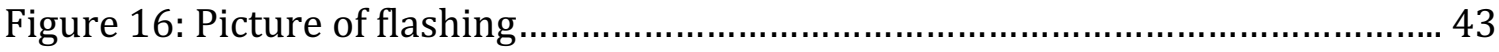

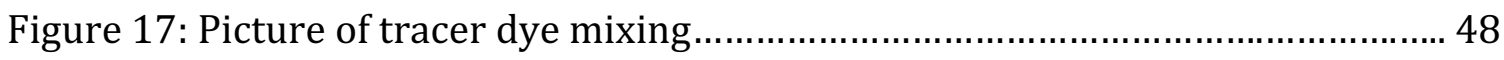

Figure 18: Portland State Geography Department Soil Lab......................................... 49

Figure 19: Picture of Moto Pool stormwater sample site.......................................... 59

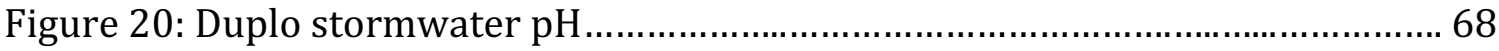

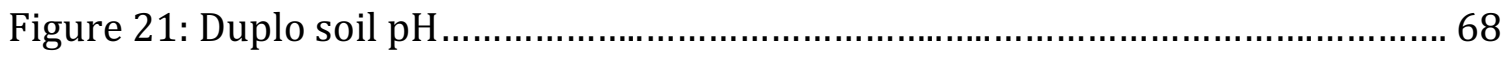




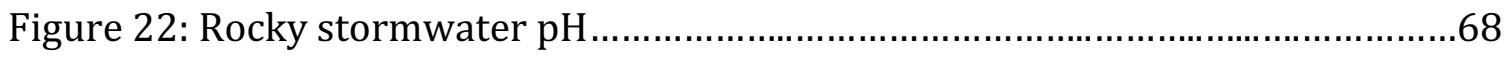

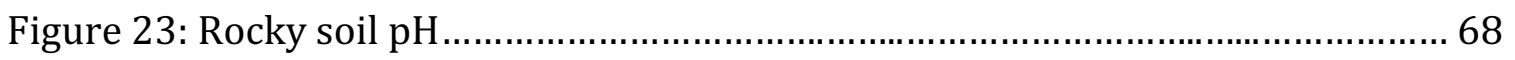

Figure 24: Duplo stormwater phosphorus............................................................ 73

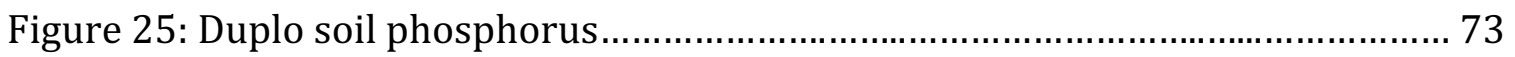

Figure 26: Rocky stormwater phosphorus.............................................................. 73

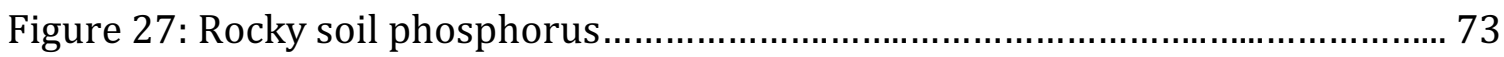

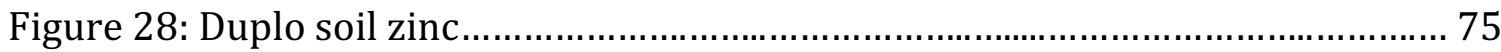

Figure 29: Duplo stormwater zinc levels.......................................................... 75

Figure 30: Rocky soil zinc............................................................................. 75

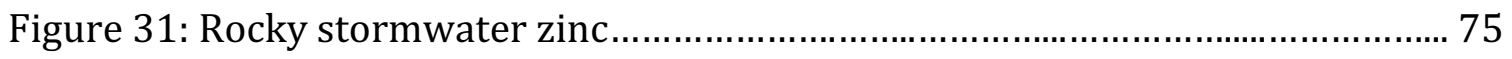

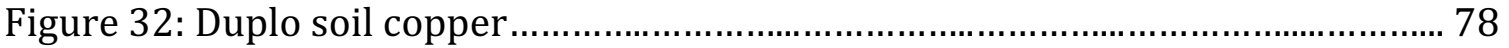

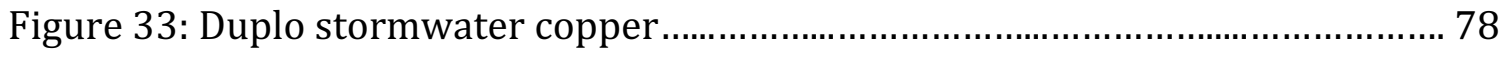

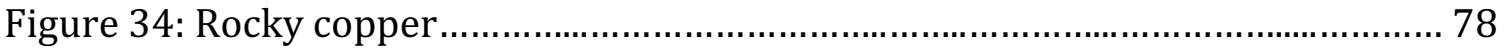




\section{Chapter 1: Introduction}

Urban development and its concomitant increase in impervious surfaces negatively affects urban water quality and watershed connectivity. Because of this, urban stormwater runoff is a significant issue for urban watershed health. The increase in the percent of impervious surfaces in developed areas results in less infiltration into soil, which reduces nutrient processing and uptake by vegetation; hence, street level pollutants often end up being transported directly into the stream system (Walsh et al. 2005). Onsite stormwater filtration using ecologically engineered structures, such as bioswales, provides urban water resource managers with effective solutions for reducing and filtering stormwater runoff. In this study, I assess if bioswales containing stormwater filter media can be enhanced by the application of mycoremediation, also known as fungal bioremediation (Singh 2006; Stamets 2005).

Over the past several decades, water resource managers and urban planners have started embracing an approach that attempts to use processes found in nature for remediation, restoration, and sustainable resource management using ecologically engineered structures like bioswales and ecoroofs (Water Environment Research Foundation 2009). The objective of this study is to test the effectiveness of applying mycoremediation to reduce metal levels in urban stormwater and bioswale soil and stormwater.

Stormwater runoff is an important issue for urban watersheds and receiving waters, as it directly affects stream characteristics and pollution levels (Walsh et al. 
2005). Infiltration based stormwater structures using soil and vegetation offered an environment well suited to testing mycoremediation to assess if fungi could increase the effectiveness of stormwater filter media, and possibly increase the longevity of these ecologically engineered structures.

This study focused on applied mycoremediation and mycofiltration; I explored methods and materials that could be viable and scalable for projects that do not have the capacity for sterile fungi cultivation. In this project, a shelf stable general purpose biotic soil blend featuring mycorrhizae and formulated for agricultural purposes was applied to stormwater filter media in order to test the effectiveness of mycoremediation to ameliorate zinc, copper, and phosphorus in a relatively old bioswale (aged 20 years) with established vegetation.

\section{Significance: Stormwater, Metals, and Urban Water Quality}

Urban stormwater runoff has become an increasingly important issue for urban water quality managers as populations concentrate and impervious surface area continues to increase (Feist et al. 2011; Göbel et al. 2006; Walsh et al. 2005). Stormwater runoff contains significant levels of heavy metals including zinc, copper, lead, and cadmium, as well as hydrocarbons, and polycyclic aromatic hydrocarbons (PAHs) (Göbel et al. 2006). Because of this, polluted stormwater contributes to contaminant levels in surface waters, groundwater, and seepage water (Göbel et al. 2006). The increase in impervious surfaces and direct discharges from stormwater drainage systems have been identified as the most significant causes of urban stream syndrome, which is characterized by changes in water chemistry, increased 
pollution and nutrient concentrations, habitat degradation, and reduced channel complexity (Walsh et al. 2005).

The research by Walsh et al. (2005) on urban stream syndrome relates the relationships among stormwater, impervious surfaces, and urban stream health. Impervious surfaces cause runoff to bypass natural filtration processes; the surface flowing stormwater entrains road pollutants and trash, which then get flushed into drainage systems and receiving waters at a faster rate and volume. The increased runoff and higher flow events result in distinct changes to the hydrograph and geomorphology of urban streams (Walsh et al. 2005).

In order to address urban stream syndrome and issues with urban watershed health, agencies and restoration practitioners are working to increase onsite infiltration of stormwater runoff with strategic Green Street plantings and the installation of structures designed to collect and filter stormwater runoff, such as bioswales, bioretention cells, infiltration planters, and ecoroofs (Stormwater Solutions Handbook BES 2015). Originally, stormwater management was focused on flood control and reducing the impact of stormwater on sewer systems. However, attention has recently shifted toward also addressing water quality as more is learned about the effect stormwater has on contaminant levels, aquatic habitat, urban streams, and watershed connectivity, given that stormwater runoff is now widely recognized as a source of pollution for streams, rivers, and receiving waters (Göbel et al. 2006; Oregon DEQ 2003; Davis et al. 2000). 
Within this setting there is a growing body of research exploring the use of natural processes to address soil and water contamination. Practitioners are increasingly implementing bioremediation and ecological engineering in urban stormwater management (Sustainable Stormwater Symposium 2015; Stormwater Solutions Handbook BES 2015; Sustainable Site Development BES 2003). Infiltration-based stormwater management structures result in increased contact between stormwater runoff with soil and vegetation, which facilitates bioremediation strategies like phytoremediation, remediation using plants, and mycoremediation with fungi.

Bioremediation uses biological processes (Gadd 2001) and soil organisms to to restore or decontaminate polluted soils (Brady and Weil 1999). Mycoremediation refers to fungal bioremediation, the use of fungal digestive and decomposing properties to accumulate and process metals, nutrients, bacteria, silt, and toxins (Gusse and Volk 2014; Cotter 2014; Singh 2006; Stamets 2005). Mycelia, networks of fungal filaments, have demonstrated the ability to absorb and break down a broad range of pollutants, including bacteria, toxic chemicals, heavy metals, and petro-based compounds (Gusse and Volk 2014; Singh 2006; Stamets 2005). Mycofiltration applies these strategies to water filtration using mycelial networks as a biologically active filter (Taylor and Stamets 2014; Stamets et al. 2013; Stamets 2005).

The focus of this inquiry is on mycorrhizal fungi, which develops a symbiotic relationship with plant species that protects them from stress and toxicity while 
increasing the area that the roots can tap for nutrients and moisture (Schaetzl and Thompson 2015; Singh 2006; Gadd 2001; Khan et al. 2000).

\section{Guiding Questions}

Questions about how the application of mycoremediation could enhance naturally occurring filtration processes for the benefit of urban stream health originally inspired this inquiry. The challenges of monitoring the effects of mycoremediation directly in a stream's hyporheic zone shifted the focus toward treating polluted stormwater prior to it entering surface water. This inspired questions about how effectively treatment using mycoremediation could reduce metal levels in bioswale soil and stormwater. Bioswales provided a contained filtration unit, made of soil and vegetation, that was a good candidate for the application of fungi which support plant health, nutrient processing, and bioremediation.

Many species being used in mycoremediation require sterile cultivation, which creates limitations for scalability. The focus of this in situ study was to determine if an easily applied and commercially available fungal blend could be used successfully in mycoremediation by supporting and contributing to treatment of stormwater through soil filtration. This study took place over several months during the rainy season in the Pacific Northwest. It remains uncertain what residence time is needed for stormwater mycofiltration to be effective. Hence, in many regards this study was a proof of concept exploring limitations, issues, and questions about the use of mycoremediation in the field. There remain questions 
about the lifespan of mycelial bodies that have hyper-accumulated heavy metals, the type of maintenance regime needed for mycoremediated bioswales, and which plant and fungal partners are best suited for ameliorating different contaminants in different geographic regions. These questions are relevant to the potential application of mycoremediation into stormwater facilities management, and highlight the importance of field and lab studies that help elucidate variables while working towards practical solutions for in situ bioremediation in stormwater management. 


\section{Chapter 2: Background}

When water moves through soil that is pervious, or porous, there is a natural filtration process that occurs as water interacts with ions, minerals, vegetation, and microorganisms (Brady and Weil 1999). In urban areas, impervious surfaces reduce the surface area where water can infiltrate increasing the amount of precipitation that becomes surface runoff that bypasses natural filtration processes (Walsh et al. 2005). Thus, many ecological engineering strategies focus on improving stormwater management in urban areas by increasing pervious surface area and the infiltration capacity of space that is available (Passeport et al. 2013).

\section{Bioremediation}

There are many forms of bioremediation that demonstrate how soil organisms and natural processes can be used to address soil pollution. Bioremediation refers to biological remediation (Gadd 2001), often using soil organisms to address pollution (Brady and Weil 1999). Phytoremediation is the use of plants to immobilize, degrade, or remove organic and inorganic soil pollutants, including heavy metals, pesticides, solvents, crude oil, and polycyclic aromatic hydrocarbons (Khan et al. 2000). Phytostabilization and phytoextraction are two main types of phytoremediation (Krämer 2005).

Rhizofiltration is the absorption of contaminants through the root zone rhizosphere, where roots and soils interface (NRCS Soil Quality 2000). Most plants have adapted mechanisms which allow for high levels of toxins to exist in their rhizosphere (Khan et al. 2000). The root zone rhizosphere is an active area for 
nutrient and chemical accumulation and decomposition due to the high level of enzyme activity from plant roots and their symbiotic fungal partners (Schaetzl and Thompson 2015; Leyval and Joner 2001; Hinsinger 2001). Dilution with clean soil, immobilization using techniques such as phytostabilization, and soil washing are all on-site methods to address soil with heavy metal toxicity (Khan et al. 2000). Extraction and burying off-site are also options, but these methods have limited scalability due to high costs (Khan et al. 2000).

Phytoextraction is especially effective with nickel, zinc, and copper, as these metals tend to be more easily absorbed by hyperaccumulating plants (USDA NRCS Soil Quality 2000). At least 400 plants are known to be hyperaccumulators (Krämer et al. 1997), plants that accumulate metals without toxicity (Krämer 2005). Some hyperaccumulators have been reported to accumulate more than $40,000 \mathrm{mg} / \mathrm{kg}$ of zinc, $20,000 \mathrm{mg} / \mathrm{kg}$ of nickel, and $1000 \mathrm{mg} / \mathrm{kg}$ of cadmium (Brady and Weil 1999).

Because of the relationship between plant and fungal partners, active processes used in phytoremediation and mycoremediation often occur in conjunction, whether or not that is the intended purpose.

\section{Fungi and Mycoremediation}

Fungi are ubiquitous and are known to play important roles in decomposition, nutrient cycling, and soil formation (Finlay 2008; Singh 2006; Brady and Weil 1999). A conservative working estimate for the total number of fungal species globally is 1.5 million, with estimates ranging between 500,000 and nine million (Hawksworth 2001). The mushrooms that many are familiar with, the above 
ground fungal 'fruit' or 'flower', represent a small portion of the fungal organism whose body exists primarily underground (Brady and Weil 1999).

Most plants have mycorrhizal associations where plant and fungi exist symbiotically (Schaetzl and Thompson 2015; Leyval and Joner 2001; Brady and Weil 1999; Smith and Read 1997). Fungi support plant health by mobilizing nutrients like nitrogen and phosphorus, which would otherwise be unavailable to the plant (Singh 2006; Gadd 2001; Finlay 2008). The word mycorrhiza translates to "fungus root", reflecting this relationship between fungi and plant partners (Schaetzl and Thompson 2015, 101; Brady and Weil 1999, 428).

Mycorrhizal symbiosis between fungi and plants has been a defining force in the development of terrestrial ecosystems, and plant communities who dominate do so because this relationship with fungi has given them an evolutionary advantage (Finlay 2008; Read and Moreno 2003). Cornelissen et al. (2001) asserted that mycorrhizal symbiosis is such a key part of how plants interact with their environment that it should be a part of plant classification.

Fungi play a critical role in succession after disturbances, often being the first to arrive after degradation, decomposition, or fire (Stamets 2005; Arora 1986). As decomposers they break down compounds and waste, facilitating succession and playing a key role in decomposition, nutrient cycling, and soil formation over time (Finlay 2008; Stamets 2005).

Through their presence and participation in the decomposition process and chemical weathering, mycorrhiza are active agents in soil ecology and soil formation 
(Schaetzl and Thompson 2015; Finlay 2008). Mycelium move nutrients and break down both organic and inorganic compounds, channeling nutrients to plants and increasing the surface area the root system can tap into for water and nutrition (Schaetzl and Thompson 2015; Finlay 2008; Singh 2006; Khan 2000; Brady and Weil 1999).

Mycelium play a role in carbon sequestration such that researchers report between $15 \%$ to $28 \%$ net carbon fixation resulting from the energy cost for maintaining mycorrhizal associations (Finlay 2008). A possible advantage of having an independent source of carbon is that mycelium can tap into this carbon energy source to allow for growth into contaminated areas (Finlay 2008). Symbiosis with mycorrhizal fungi also helps plants access nutrients with less of a carbon energy cost (Leyval and Joner 2001).

As mycelial webs form, the enzymes they produce release nutrients, while the individual filaments, hyphae, aerate the soil and create soil stability with an interactive web connected to plant root systems, soil, and geologic material (Schaetzl and Thompson 2015; Finlay 2008; Stamets 2005). This fungal web, also known as a mycelial mat (Schaetzl and Thompson 2015), or a mantle (Leyval and Joner 2001), functions as connective tissue in soil ecosystems by responding to changing chemical conditions and shifting or moving nutrients as needed (Finlay 2008; Singh 2006). Fungal organisms are known to transfer nutrients between different tree organisms and species, based on individual needs and environmental conditions (Beiler et al. 2010; Brady and Weil 1999). Mycorrhizal associations 
between Rhizopogon fungi, one of the species used in this study, have been known to aid in Douglas fir (Pseudotsuga menziesii) seedling establishment, growth, and resiliency (Beiler 2010; Molina et al. 1999). Fungal hyphae, the individual filaments, are known to stretch $5-10 \mathrm{~cm}$ from plant roots, which increases the absorptive surface area of the root system by up to 10 times (Brady and Weil 1999).

Two and a half cubic centimeters ( 1 cubic inch) of soil is estimated to have up to $13 \mathrm{~km}$ (8 miles) of hyphae (Figure 1) (Gusse and Volk 2014), which functions as a biological filter (Damodaran et al. 2013) absorbing and processing microbial pathogens like bacteria, fungi, and protozoa, as well as particulate runoff and toxic chemicals, such as antibiotics and fertilizers (Gusse and Volk 2014). Mutualistic and saprophytic, decomposing fungi can be used to remove pollutants, sediment, and bacteria from both groundwater and streams (Gusse and Volk 2014). Mycelial enzymes can degrade a wide range of sturdy toxic chemicals into inert compounds (Gusse and Volk 2014), and mycelium can hyperaccumulate heavy metals (Singh 2006; Stamets 2005). Mycorrhizal fungi have both direct and indirect mechanisms for solubilizing and immobilizing metal compounds (Gadd 2001; Leyval and Joner 2001). Hence, not only do mycorrhizal fungi have an important role in protecting plants

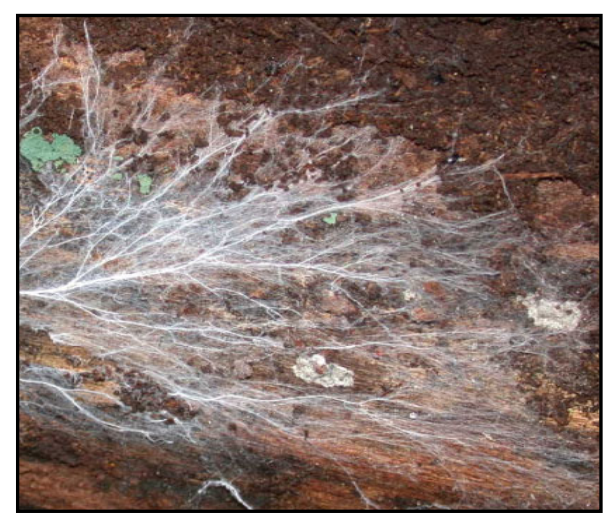

Figure 1: Mycelial filaments, called hyphae, running through the soil. One cubic inch of soil is estimated to have up to eight miles $(13 \mathrm{~km})$ of hyphae from heavy metal toxicity (Finlay 2008; Singh 
2006; Fomina et al. 2005), but they can also play a role in rhizosphere remediation (Singh 2006; Khan et al. 2000).

There are seven types of mycorrhizal fungi, with two primary forms having practical significance, endomycorrhizal fungi and ectomycorrhizal fungi (Brady and Weil 1999). Endomycorrhizal fungi, also known as arbuscular mycorrhizae (AM) and formerly known as vesicular-arbuscular mycorrhizal (VAM) fungi, puncture the plant root wall with their hyphae (Singh 2006; Brady and Weil 1999). The arbuscular mycorrhizal association is the most common and wide-spread (Finlay 2008; Smith and Read 2008; Singh 2006; Brady and Weil 1999). Roughly two thirds of plants have this arbuscular association, the oldest known fungal plant association, where colonization occurs as mycorrhiza scavenge for phosphate (Singh 2006). The arbuscular symbiosis occurs with up to 250,000 plants, spanning a large range of species (Finlay 2008). Most trees, and agricultural and herbaceous plants (Brady and Weil 1999) in Mediterranean and tropical ecosystems have an arbuscular association (Smith and Read 2008; Leyval and Joner 2001). The arbuscular mycorrhizal association is known to connect different plant organisms transferring nutrients as needed (Brady and Weil 1999), while also protecting plants from stress caused by heavy metals (Hildebrandt et al. 2006).

The ectomycorrhizal (ECM) association occurs when fungal hyphae wrap around the root system but do not penetrate the root cell wall (Finlay 2008; Singh 2006; Brady and Weil 1999). The ectomycorrhizal association is the second most common type of mycorrhizal association (Singh 2006) and tends to occur in forests 
(Smith and Read 2008) and in soil environments that have medial $\mathrm{pH}$ and organic matter levels (Leyval and Joner 2001). Ectomycorrhizal fungi excrete various organic acids that help plants access insoluble minerals like nitrogen and phosphorus (Singh 2006; Gadd 2001). It has been established that ectomycorrhizal fungi can degrade a variety of organic compounds (Singh 2006), and seem to have both a constitutive and an adaptive tolerance to metals (Meharg 2001).

Other forms of mycorrhizal fungi include: ericoid mycorrhizal fungi (ERM), which form associations with three specific plant families; orchid mycorrhiza, consisting of fungi who form associations with the orchid family; monotropid mycorrhiza, who form associations with the Monotropaceae plant family; the arbutoid mycorrhiza, who usually form associations with a handful of specific plant families that are often ectomycorrhizal; and the endoectomycorrhiza, who embody both ecto- and endomycorrhizal characteristics (Finlay 2008). This study focuses on arbuscular/endomycorrhizal fungi and ectomycorrhizal fungi.

\section{Metals in the Environment}

Cation metals are the most problematic in terms of pollution, these include mercury, cadmium, lead, nickel, copper, zinc, chromium, and manganese (NRCS Soil Quality 2000). These toxic inorganic metals are known collectively as heavy metals (Brady and Weil 1999). Heavy metal ions such as zinc, copper, and lead have a strong attraction to small biological molecules and sulfhydryl groups in proteins, and are very reactive, negatively impacting the function of biological systems (Damodaran et al. 2013). 
Heavy metals tend to accumulate in the surface layer where uptake into plants that could be consumed by other organisms is more likely, leading to entrance into the food chain. Once released into the environment, metals can bioaccumulate in the food chain, reaching toxic levels in higher trophic organisms (Leyval and Joner 2001; Brady and Weil 1999). Some metals, such as zinc, copper, and manganese, have important roles as nutrients for plants and animals, but all are toxic once the threshold of any given organism is exceeded (Leyval and Joner 2001). The combination of toxicity and a long residence time in the environment create concerns around heavy metal pollution in soil and water. Zinc and copper, in particular, are contaminants of interest for stormwater managers (Sustainable Stormwater Symposium 2015).

There are many different approaches to addressing soil and water contamination, but cost and scalability are limiting factors (Khan et al. 2000). The volume and type of contaminants present, the location, land use, and associated clean-up costs are all potential factors for what remediation method might be preferred for any given project.

Human activity is causing an increase in levels of heavy metals in the environment, risking the health of large numbers of people globally (Leyval and Joner 2001; Khan et al. 2000). Most metals are persistent, and normally do not biodegrade or break down in the environment (Walker et al. 2012). The only exceptions are mercury and selenium, which can be transformed and volatized by microorganisms (NRCS Soil Quality 2000). Clay content, organic matter, and pH are 
important factors influencing the mobility of metals, as higher levels of these metrics cause metals to bind with the soil, which results in an increased residence time (Walker at al. 2012; Brady and Weil 1999). Alternatively, heavy metals are more mobile and thus more available if the $\mathrm{pH}$ is acidic (Walker et al. 2012; Brady and Weil 1999). Some microbial processes can dissolve metals, increasing the bioavailability of the metal, and possibly the toxicity along with it, while other microbial processes immobilize metals, making them less bioavailable (Fomina et al. 2005; Gadd 2001).

Treatment of contaminated soils can be divided into two broad categories: in situ, on-site remediation, and ex-situ, removal of contaminate soil offsite (Khan et al. 2000). Managing contaminated soil on-site by attempting to immobilize the toxins is a common practice (Brady and Weil 1999). The Natural Resources Conservation Service (NRCS) has recommended on-site treatment methods for heavy metal soil contamination, including high temperature treatment to produce a material that won't leach, solidifying agents, or a washing process that leaches the contaminants (NRCS Soil Quality 2000).

Contaminated areas are often capped with an impermeable layer that prevents stormwater from flowing through the contaminated soils and leaching metals into groundwater (Walker et al. 2012). Draining wet soils is another recommended strategy as the oxidized form of these elements is less soluble, and less likely to be taken up by plants than when they are in their reduced forms (Brady and Weil 1999). Soil washing, soil dilution, and immobilization of metal 
contaminants are all established methods but remain a challenge to execute at a broad scale (Khan et al. 2000).

\section{Stormwater Contaminants and Toxicity}

Stormwater runoff is a source of toxic pollution for receiving waters in urban areas (Spromberg et al. 2015; Göbel et al. 2006; Walsh et al. 2005). Stormwater runoff contributes to contaminant levels in seepage water, groundwater, and urban streams (Göbel et al. 2006). Roof, road, and parking surface runoff are all sources of contaminated stormwater runoff (Göbel et al. 2006). Runoff from roads is a complex mixture, originating primarily from remnants of abrasion and engine liquids from automobiles (Spromberg et al. 2015; Göbel et al. 2006). Common stormwater contaminants include the heavy metals lead, zinc, copper, and cadmium, along with polycyclic aromatic hydrocarbons, and mineral oil hydrocarbons (MOH) (Göbel et al. 2006). Stormwater is a significant source of heavy metal pollution (Tiefenthaler et al. 2008). Sources of heavy metals in stormwater include dust particles from industrial operations, waste incineration, and vehicle traffic (Göbel et al. 2006).

There is spatial variability within stormwater pollutant concentrations as a result of unique runoff conditions for different impervious surfaces, varying levels of automobile use and density, shifting weather conditions, and varying levels of technology (Göbel et al. 2006). In addition, a significant spatial correlation has been found between land use, the amount of impervious surfaces and roads, and prespawn coho salmon mortality in western urban watersheds in the United States (Spromberg 2015; Feist et al. 2011). The weight of evidence indicates that 
stormwater is toxic to adult coho salmon spawning during the fall season (Scholz et al. 2011; Feist et al. 2011).

The seasonality of stormwater is of environmental significance as the previous example illustrates. There is temporal and seasonal variation in precipitation that can influence pollutant load levels. First flush conditions occur after contaminants have built up during a dry period resulting in a concentrated dose of pollution at the onset of precipitation conditions (Göbel et al. 2006).

\section{Fungal Remediation of Metals}

As human activities continue to increase metal levels in the environment, and high costs limit off-site removal as a viable, scalable solution, on-site solutions such as phytoremediation (Khan et al. 2000) and mycoremediation (Singh 2006) are being explored. Potential for remediation using mycorrhizal fungi, and the relationship between mycorrhiza, plant health, and contaminants has received attention (Finlay 2008; Singh 2006; Hildebrandt et al. 2007; Fomina et al. 2005; Gadd 2001; Leyval and Joner 2001; Khan et al. 2000; Meharg and Cairney 2000; Tam 1995; Shetty et al. 1994; Hetrick et al. 1993; Heggo and Angle 1990; Denny and Wilkins (IV) 1987; Morselt et al. 1986) and become an area of research that is contributing to the bourgeoning realm of mycoremediation.

Mycorrhizal fungi have been found in metal polluted sites and have demonstrated tolerance to metals (Fomina et al. 2005; Gadd 2001; Leyval and Joner 2001; Brady and Weil 1999; Tam 1995; Morselt et al. 1986). Mycorrhizal fungi are found at the interface between plant roots and the soil matrix, connecting the two 
and influencing plant uptake of metals in response to the type and concentration of metal mineral, and the fungal species and its genotype (Leyval and Joner 2001). Heavy metal mobility and uptake is a function of soil and plant factors, including $\mathrm{pH}$, nutrient levels, soil porosity, clay levels, and the chemical form of the heavy metal (Khan et al. 2000).

The form that a metal mineral appears in will affect uptake potential. Factors including $\mathrm{pH}$, chemical composition, redox potential, and ionic strength will all have an effect on what chemical form a metal will be and the strength of the bond with any molecules or ions it's attached to (Deiana et al. 2001). The rhizosphere zone is home to organic acids and root exudates which form stable complexes and chelates with a range of metals (Leyval and Joner 2001). Plant roots and hyphae release organic acids into the rhizosphere zone (Gadd 2001), essentially equivalent to the mycorrhizosphere zone since most plants have mycorrhiza (Leyval and Joner 2001).

Leyval and Joner (2001) report on three main ways that mycorrhizal fungi influence the bioavailability of metals: 1) Direct physical influence through adsorption, absorption, and accumulation which can stabilize and sequester metals; 2) Direct chemical effects that result in mineral solubilization; and 3) Indirect influence on plant root exudates that affect the chemical environment of the mycorrhizosphere. Mechanisms for fungal tolerance to metal toxicity are binding and precipitation (Leyval and Joner 2001). Mechanisms that dominate fungal solubilization of metal minerals are related to protonation, complexation, and the production of siderophores (Fomina et al. 2005; Gadd 2001). 
In lab research, Fomina et al. (2005) concluded that many ericoid and ectomycorrhizal fungi have the ability to solubilize different toxic metal-containing minerals, releasing toxic metal components in the solubilization process. Of the metals tested, zinc was the least toxic to most of the fungal species and was the easiest to dissolve. They also found that solubilization and fungal growth levels were not necessarily connected (Fomina et al. 2005).

In ectomycorrhizal fungi the method of intracellular metal detoxification appears to be the production of polyphosphates that bind to metal cations (Singh 2006). It is reported that most studies showing ectomycorrhizal fungi supporting plant hosts from heavy metal toxicity do so by preventing the movement of the metals into the host body (Khan et al. 2000). Arbuscular endomycorrhizal and ectomycorrhizal fungi are both known to accumulate metals in their extramatrical hyphae and extrahyphal slime (Singh 2006; Tam 1995).

Pisolithus tinctorius (Figure 2), the primary ectomycorrhizal species used in this study, has been known to tolerate and accumulate heavy metals (Khan et al. 2000; Tam 1995). Khan et al. reported on Turnau and other's 1994 findings that cadmium,

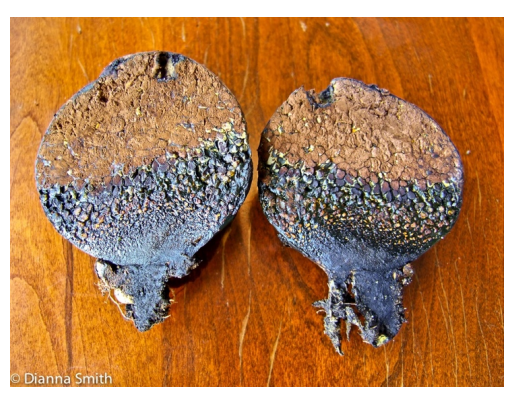

Figure 2: Pisolithus tinctorius fruit copper, and iron have all been found concentrated in the outer layer of the cell wall of Pisolithus tinctorius (Khan et al. 2000). Pisolithus tinctorius can maintain its health and function in the presence of high concentrations of metals, including zinc, copper, aluminum, and iron (Tam 1995; Morselt et al. 1986). This high tolerance to metals is 
a function of the presence of metal binding proteins such as metallothionein and metallothionein-like peptides which are produced after exposure to zinc, copper, and cadmium (Morselt et al. 1986). Metallothionein proteins bind with toxic metals helping to regulate internal concentrations (Khan et al. 2000). A mechanism for tolerance and amelioration of zinc and copper is phosphate linkage in the extrahyphal slime (Tam 1995). Pisolithus tinctorius is a species commonly used in tree nurseries and is known to increase tree growth between $50-500 \%$ in infertile soils (Brady and Weil 1999).

Species in the Rhizopogon family, another form of ectomycorrhizal fungi, are also used in this study. Research has shown that Rhizopogon species have diverse sources of energy resulting from symbiosis with multiple Douglas fir trees in a web that supports the establishment of seedlings by moderating the flow of nutrients through space and time and between trees of different generations (Beiler et al. 2010). Research has found that a single Rhizopogon organism can connect as many as 19 Douglas fir trees of various ages (Beiler et al. 2010). This mycorrhizal association can be seen in Figure 3.

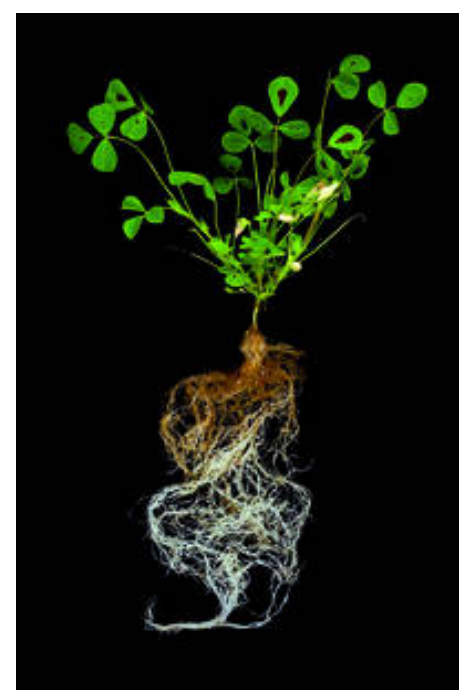

Figure 3: Rhizopogon association with Medicago truncatula

The endomycorrhizal fungi used in this study are all from the Glomus family. Glomus intraradices is a common species of arbuscular mycorrhizal fungi reported to produce zinc transporter genes (Hildebrandt et al. 2007). Arbuscular 
endomycorrhizal fungi are known to support plant health and increase resistance to stress induced by metals (Hildebrandt et al. 2007), in addition to accumulating metals in their extramatrical hyphae and extrahyphal slime (Singh 2006; Tam 1995).

Because mycoremediation is a relatively recent field of scientific inquiry there is limited research and many questions that remain. There is more peerreviewed research available on the ectomycorrhizal species in this study than the endomycorrhizal species.

Fortunately, the PermaMatrix ${ }^{\circledR}$

blend is dominated by ectomycorrhizal species in both the number of species and the quantity (Table 1).

There are seven species of ectomycorrhizal fungi present in PermaMatrix ${ }^{\circledR}$ BSP

Foundation, which collectively

total 4844 propagules per gram, as compared to four

\begin{tabular}{|c|c|c|}
\hline \multicolumn{3}{|c|}{$\begin{array}{c}\text { Mycorrhizal Test Media: PermaMatrix } \\
\text { Propagules/ }\end{array}$} \\
\hline Pisolithus tinctorius & 3964 & ectomycorrhizal \\
\hline Rhizopogon villosullus & 110 & ectomycorrhizal \\
\hline Rhizopogon luteolus & 110 & ectomycorrhizal \\
\hline Rhizopogon amylopogon & 110 & ectomycorrhizal \\
\hline Rhizopogon fulvigleba & 110 & ectomycorrhizal \\
\hline Scleroderma cepa & 220 & ectomycorrhizal \\
\hline Scleroderma citrine & 220 & ectomycorrhizal \\
\hline Glomus intraradices & 1.1 & endomycorrhizal \\
\hline Glomus mosseae & 1.1 & endomycorrhizal \\
\hline Glomus aggregatum & 1.1 & endomycorrhizal \\
\hline Glomus etunicatum & 1.1 & endomycorrhizal \\
\hline Bacteria Species & CFU/gm & \\
\hline Azospirillum lipoferum & $1.10 \times 10^{12}$ & Nitrogen Fixer \\
\hline Azospirillum brasilense & $1.10 \times 10^{12}$ & Nitrogen Fixer \\
\hline Bacillus subtilis & $2.57 \times 10^{12}$ & $\begin{array}{l}\text { Biochemical } \\
\text { Decomposer }\end{array}$ \\
\hline Bacillus licheniformus & $2.06 \times 10^{12}$ & $\begin{array}{l}\text { Biochemical } \\
\text { Decomposer }\end{array}$ \\
\hline Bacillus amyloliquefaciens & $5.15 \times 10^{11}$ & $\begin{array}{l}\text { Biochemical } \\
\text { Decomposer }\end{array}$ \\
\hline
\end{tabular}

Table 1: PermaMatrix ${ }^{\oplus S P}$ Foundation ingredients. CFU = colony forming units

total endomycorrhizal species, totaling only 4.4 propagules per gram. 


\section{Ecological Engineering}

Ecological engineering focuses on designing ecologically based waste management systems, which alter the ecology of a space, to provide mutual benefit for humans and the environment (Passeport et al. 2013; Mitsch 1992). Projects often attempt to enhance ecological systems and processes to levels above their natural state in order to meet human needs (Palmer et al. 2014). Many ecological engineering projects are focused on wastewater and

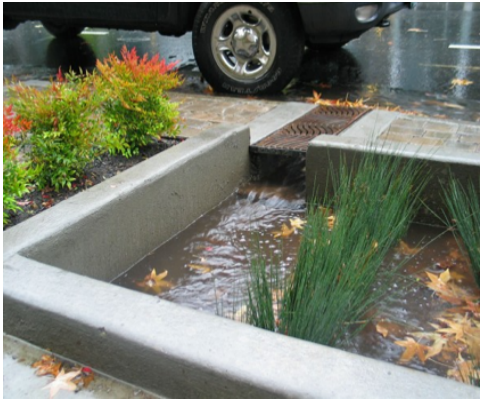

Figure 4: Bioretention cell collecting stormwater (BES 2015) stormwater management and treatment and include green/eco roofs, permeable pavers, treatment wetlands and ponds, stream restoration, and bioretention cells (Figure 4) (Passeport et al. 2013).

Many ecologically engineered structures are essentially engineered microcosms, contained urban biomes that filter waste and water through soil and vegetation. The research presented here focuses on ecologically engineered stormwater structures called bioswales (Figure 5), which provide a contained environment that is well suited to the application of mycoremediation and mycofiltration.

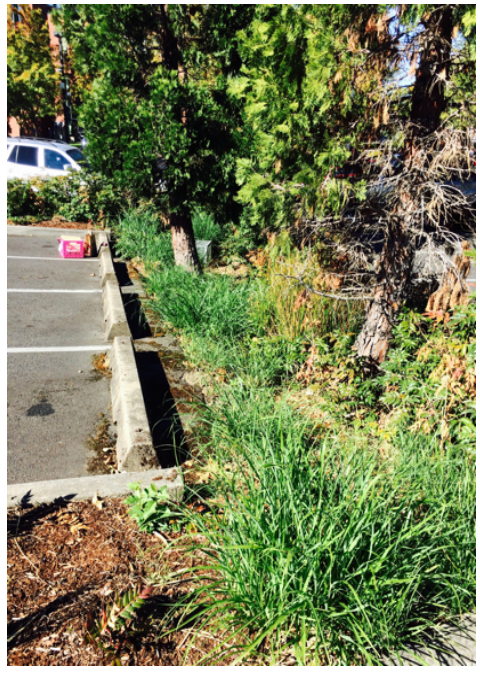

Figure 5: Infiltration-based bioswale used in study, irrigated to maintain plant health 


\section{Bioswales and Bioremediation}

Bioswales collect stormwater runoff, slow infiltration rates, and capture pollutants and sediment (Portland BES 2015; Oregon DEQ 2003). The term 'bioswale' is often used as an umbrella term for vegetated catchments used to collect and infiltrate stormwater runoff (Oregon DEQ Soil Quality 2003). Bioswales reduce the volume and the rate of water flowing into drainage systems (Passeport et al. 2013), thus reducing stress on the drainage infrastructure, and decreasing the flashy discharge into the streams and receiving waters that is associated with impervious surfaces (Oregon DEQ 2015; Portland BES 2015).

The Oregon Department of Environmental Quality has reported on results from various studies and found that bioswales reduce metals found in stormwater runoff by $20-60 \%$. Bioswales have been reported to remove high levels of total suspended solids, oil and grease, along with intermediate levels of metals and nutrients from stormwater runoff. The lower removal of metals and nutrients is attributed to the fact that in runoff a large percentage of these compounds appear in dissolved form or as microscopic particulates which are only partially removed by biological uptake (Oregon DEQ 2003).

Infiltration of highway stormwater runoff through a soil column in a lab setting resulted in a 58\% reduction in total metals, and a $94 \%$ reduction in polycyclic aromatic hydrocarbons (Spromberg et al. 2015). Amounts of dissolved metal concentrations were also reduced by infiltration through the soil columns, and stormwater ammonia content was lowered by 92\% (Spromberg et al. 2015). 
Bioswales can remove metals or nutrients attached to suspended soil particles after the solids settle through naturally occurring flocculation and uptake by vegetation (Oregon DEQ 2003). However, plant life cycles will affect this mobility and the rate at which metals and nutrients are absorbed or immobilized by a particular plant (Deiana et al. 2001). Soil composition, temperature, $\mathrm{pH}$, moisture levels, and organisms present all influence the mobility, decomposition, and bioavailability of nutrients and pollutants in a soil matrix (Schaetzl and Thompson 2015; Brady and Weil 1999). Soil organisms, like plants, fungi, and bacteria have important roles in nutrient cycling, decomposition, and thus soil filtration (Brady and Weil 1999).

\section{Biochar}

Biochar is a material of interest for stormwater filtration (Sustainable Stormwater Symposium 2015). In short-term column studies conducted by Oregon State University, Sunmark Environmental, and OregonBEST, biochar has been found to reduce levels of zinc and copper in real stormwater. A blend of $25 \%$ reed sedge peat and 75\% biochar achieved a 99\% mean reduction in copper and a mean reduction of $100 \%$ zinc from roof runoff spiked to $200 \mathrm{ug} / \mathrm{L}$ of copper and 1500 ug/L zinc. Surface runoff with the same blend of $25 / 75$ had a $97 \%$ mean reduction of copper and 98.5\% mean reduction of zinc (Gray 2015, unpublished data).

Additional lab and field research by the same group summarized at the 2015 Sustainable Stormwater Symposium, has shown that rinsed biochar can be effective in reducing heavy metals and nutrients. There is variation in results with different 
types of biochar and depending on whether the biochar was rinsed or not. Rinsing biochar is important to reduce the possibly of leaching through a nutrient pulse. Screening for properties in the selection of source material for biochar is also crucial and will affect filtration results. Rinsed biochar sourced from Douglas fir trees, as used in the Earthlite stormwater filter media in this study, was a top performer in these tests. The addition of biochar to bioretention soil media was found to increase removal of pollutants, while enhancing plant growth and water holding capacity (Gray 2015, unpublished data).

\section{Coho Salmon, Stormwater, and Bioswales}

In the Pacific Northwest environmental significance of stormwater toxicity can be found in urban streams. Stormwater runoff is toxic to adult coho salmon who travel through urban streams to spawn (Spromberg et al. 2015; Scholz et al. 2011; Feist et al. 2015). Geospatial land use analysis has shown a positive correlation between levels of impervious surfaces and the extent of the coho salmon die-off (Spromberg et al. 2015). Coho salmon die-offs during spawning season have been estimated to be between 50-90\% (Spromberg et al. 2015; Feist et al. 2011; Scholz et al. 2011).

Lab studies were conducted on stormwater toxicity and bioinfiltration in response to the high rates of pre-spawn coho mortality. Spawning season correlates with fall rains, which tend to have higher pollutant levels as a result of accumulation during drier summer months. In this research, synthetic stormwater with comparable levels of heavy metals and polycyclic aromatic hydrocarbons was tested 
alongside unfiltered highway stormwater runoff collected from fall precipitation events occurring between 2012-2014. Both the synthetic stormwater and the stormwater harvested from highway runoff were filtered through soil columns. Healthy farmed salmon were then exposed to the highway runoff, the highway runoff treated by bioinfiltration, and artificial stormwater (Spromberg et al. 2015).

Spromberg et al. (2015) reported that the coho exposed to unfiltered highway stormwater experienced $100 \%$ mortality, which is in dramatic contrast to the coho who were exposed to highway stormwater filtered through the soil columns who experienced $0 \%$ mortality. All of the fish exposed to highway stormwater were dead within 24 hours, compared to $0 \%$ dead in the control group. All of the fish exposed to filtered highway runoff survived with no behavioral symptoms observed. The synthetic stormwater did not result in the same mortality or behavioral symptoms as was caused by unfiltered highway stormwater runoff. Because comparable levels of metals and hydrocarbons did not cause coho mortality, toxicity is believed to be the result of a complex mixture of pollutants or some unknown variable. Regardless of the cause, the research concluded that green street infrastructure using bioinfiltration could improve urban water quality and prevent coho salmon die-offs in urban streams (Spromberg et al. 2015).

\section{Stormwater management in Portland, Oregon}

Portland, Oregon, the study site for this research receives approximately 94 centimeters (37 inches) of rain a year (Portland BES 2015) and is situated in the temperate forests of the Pacific Northwest. According to the Water Environment 
Research Foundation (2009), Portland has been a global leader in innovating sustainable stormwater solutions since the 1990s. Stormwater managers in Portland have advanced policy that focuses on promoting on-site infiltration of stormwater and using ecologically engineered solutions in order to slow infiltration and capture pollutants and debris (Portland BES 2015; Oregon DEQ 2003).

The Water Environment Research Foundation (2009) and the City of Portland (Portland BES 2015) report on how Portland's Bureau of Environmental Services (BES) has coordinated most of these efforts. A main driver of the programs occurred when the Clean Water Act was amended to include stormwater in 1987. This resulted in federal discharge permits being issued through the Oregon Department of Environmental Quality (DEQ) under the Federal Clean Water Act and the Environmental Protection Agency (EPA). The program permit is known as the National Pollutant Discharge Elimination System (NPDES) Municipal Separate Storm Sewer System (MS4) Discharge Permit. In the City of Portland this permit program has resulted in a regulatory infrastructure focused on sustainable stormwater management (Portland BES 2015; Water Environment Research Foundation 2009).

\section{Green Streets}

One highly visible program is the Bureau of Environmental Services Green Street Program, which focuses on implementing environmentally friendly, on-site stormwater management using ecologically engineered installations (Portland BES 2015). The Bureau of Environmental Services Green Street installations include: stormwater curb extensions; stormwater street planters for areas between 
sidewalks and the street; and bioswales (Types of Green Streets 2008). Green Street locations are shown in Figure 6 in a map from the Portland Bureau of Environmental Services (2015). The research study area can be seen in the map circled lower left of center in the map.

In regard to Green Streets, the Portland Bureau of Environmental Services says:

"Green streets protect water quality in rivers and streams by removing up to $90 \%$ of pollutants. They replenish groundwater supplies, absorb carbon, improve air quality and neighborhood aesthetics, and provide green connections between parks and open space. Vegetated curb extensions improve pedestrian and bicycle safety, and calm traffic" (2015).

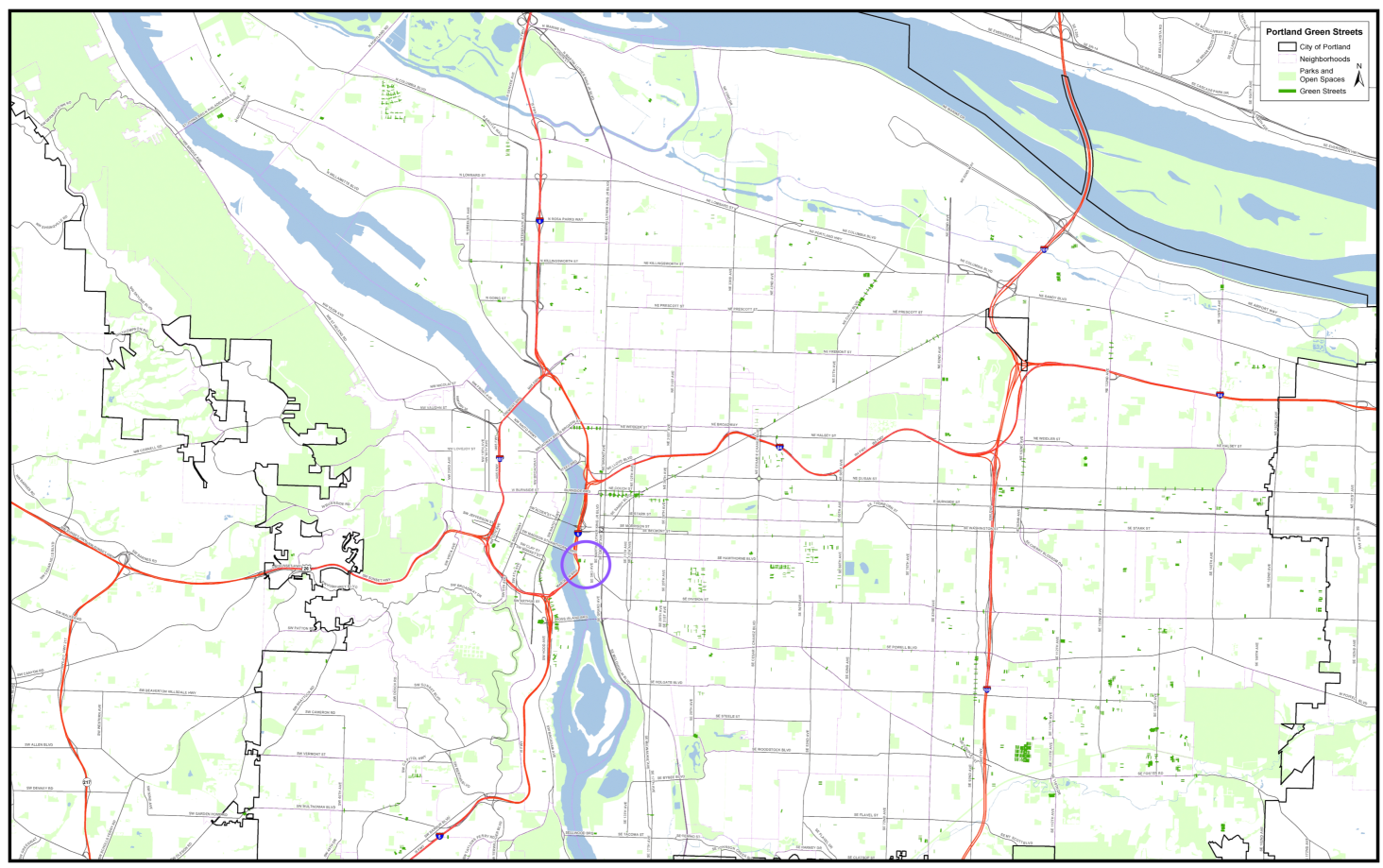

Figure 6: Green Street locations in Portland, Oregon. The research study area can be seen circled in the lower left center of the map (Portland BES 2015)

\section{Study Area}

The Portland Community College (PCC) CLIMB Campus is a centrally located workforce training center with frequently used train tracks running along the 
eastern border of the property and the Willamette River to the west. CLIMB is a part of the Bureau of Environmental Services Clay Street/Green Street network with a rain garden and educational stormwater display situated along the north side of the main building. The campus also has a large ecoroof that drains into the north facing rain garden. These Green Street features, the bioswale age and design, and the Portland Community College commitment to sustainable stormwater management, all contributed to the selection of CLIMB as a study area for this research.

The 20-year-old bioswales in the CLIMB parking lot were reported to be the second set of bioswales installed in the City of Portland (PCC, personal communication 2015). Bioswale maintenance, landscaping, and parking lot clean-up is managed by the Portland Community College Facilities and Operations Team. There was regular site clean-up weekly and a site visit after any precipitation event greater than $0.64 \mathrm{~cm}(0.25 \mathrm{inch})$ within 24 hours (PCC, personal communication 2015). The parking lot was often full, permitted for campus use during the week and used as a public parking lot and river access point on weekends (field observations 2015/2016).

The bioswales were all approximately the same width and depth, with similar vegetative composition, measuring $1.0 \mathrm{~m}$ wide and $0.5 \mathrm{~m}$ deep. The standard bioswale design pictured in Figure 7 is a good illustration of the CLIMB bioswale design.

There were four bioswales at CLIMB large enough in size to be considered for this study; they were labeled as Moto, Duplo, Rocky, and Rusty for easy 
identification. The map in Figure 8

identifies and highlights the bioswales

used, along with the study areas and

the overflow drainage network. Three

of these infiltration based bioswales

were used in this study. Due to visible

differences in soil and vegetative

composition Rusty was not included.

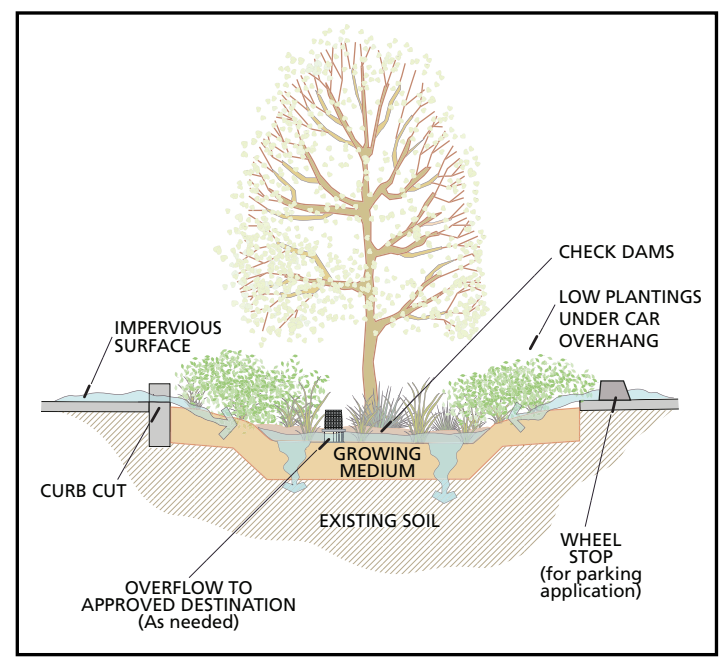

Figure 7: Standard design for an infiltrationbased bioswale (BES 2015)

The engineering map (Figure 9) shows

subsurface drainage highlighted in blue.

Duplo, the second largest bioswale, is positioned mid-way along the western side of the parking lot. Duplo is $33 \mathrm{~m}$ long, with overflow drainage positioned $6 \mathrm{~m}$ from the north end of the swale. Overflow stormwater drainage flows into a pipe that connects with the city storm system, draining directly into the Willamette River, visible in the map showing CLIMB and its surroundings (Figure 10). North of the drainage grate is labeled as 'Duplo North'. South of the grate is labeled 'Duplo South', with the 'Duplo In' $0 \mathrm{~m}$ point at the southern end, followed by the $10 \mathrm{~m}$ 'Duplo Out', 15m, and 20m (from south to north). Rusty, the largest bioswale in the lot, drains stormwater into Duplo (In) through a pipe that runs under the road separating the two bioswales. 


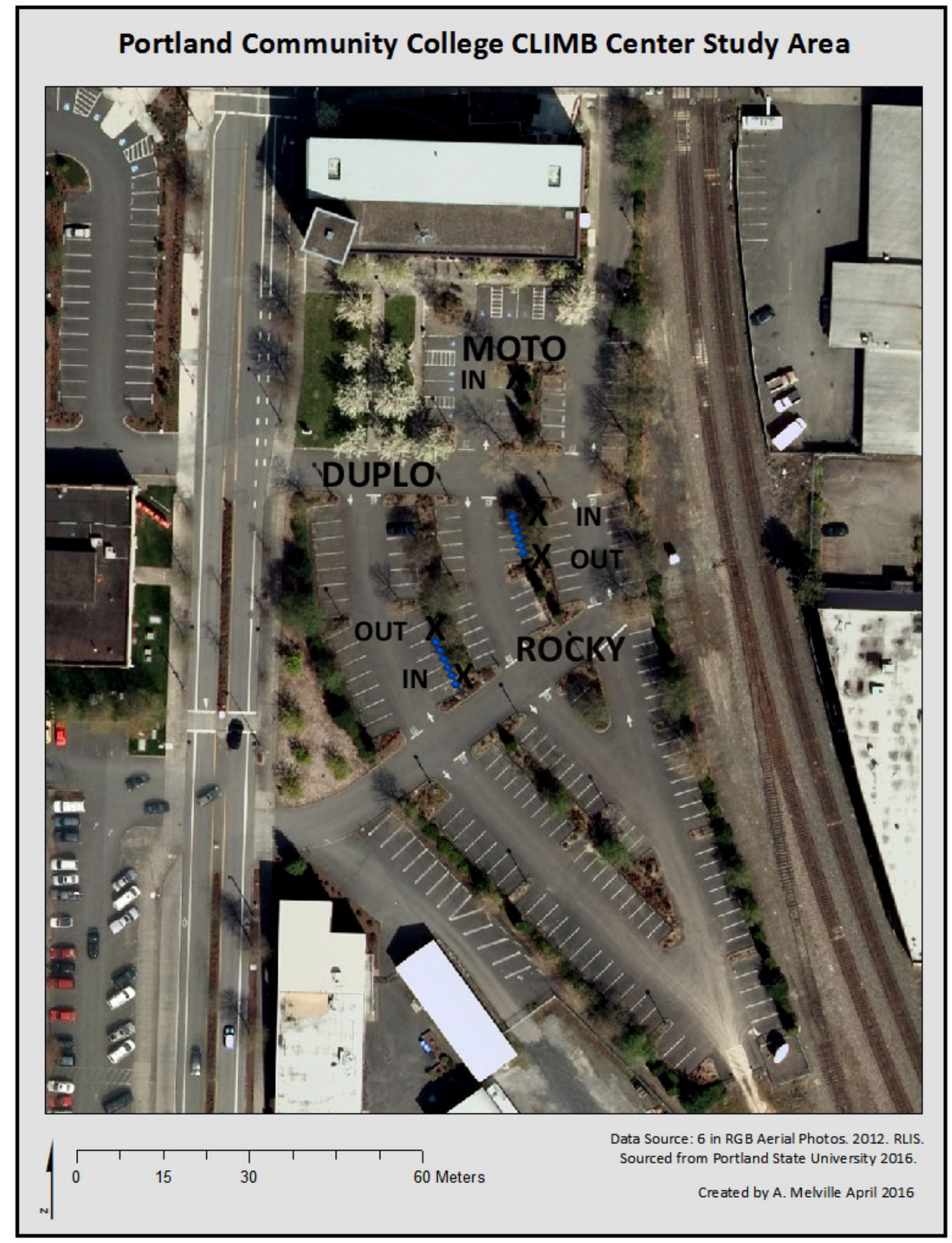

Figure 8: Map of CLIMB and the three bioswales used in this study. The blue demarks the study areas in Rocky and Duplo 


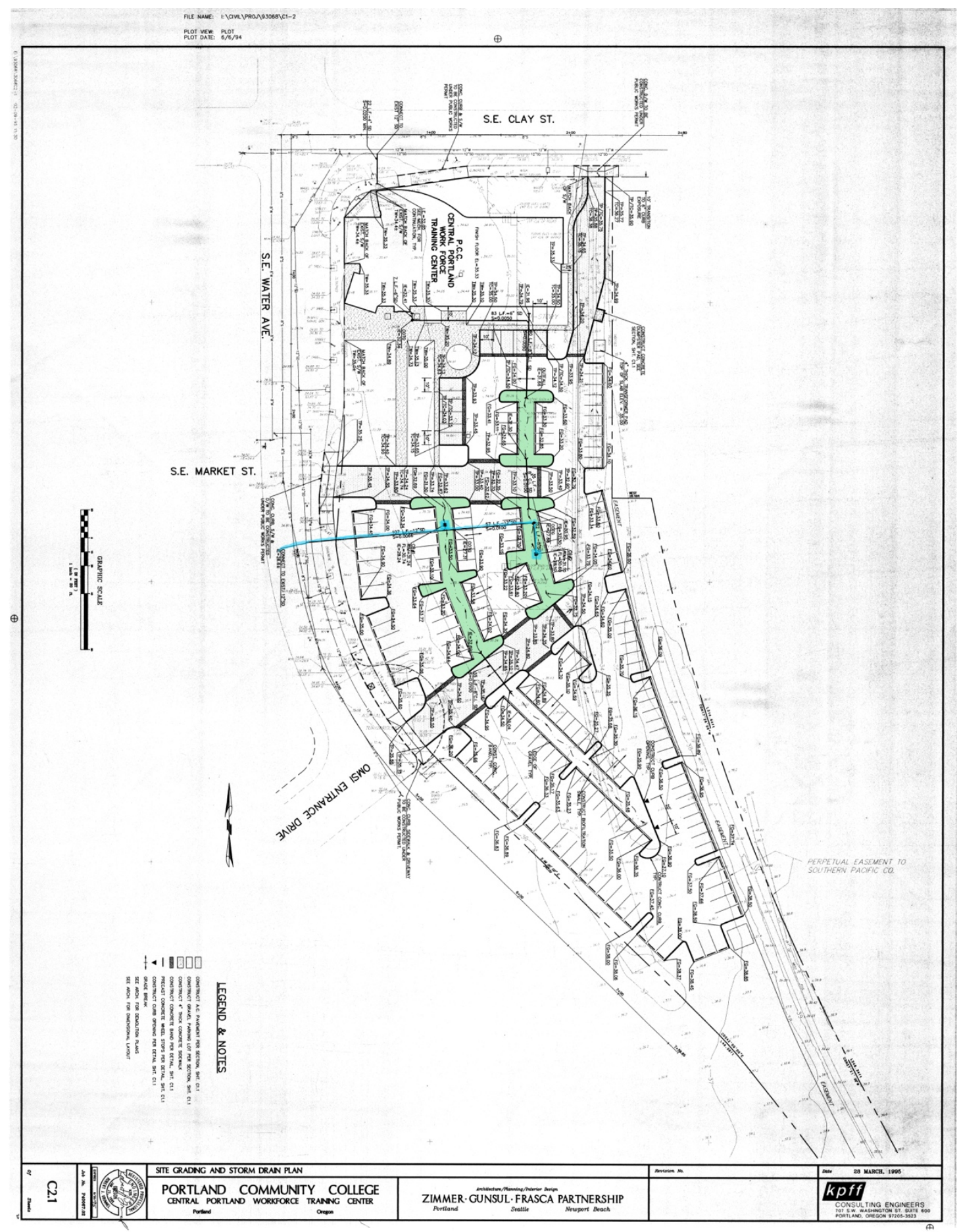

Figure 9: Engineering design showing parking lot layout and drainage. The bioswale study areas are in green, with blue highlighting the subsurface drainage that carried stormwater to the city storm system, draining directly into the Willamette River without additional filtration 


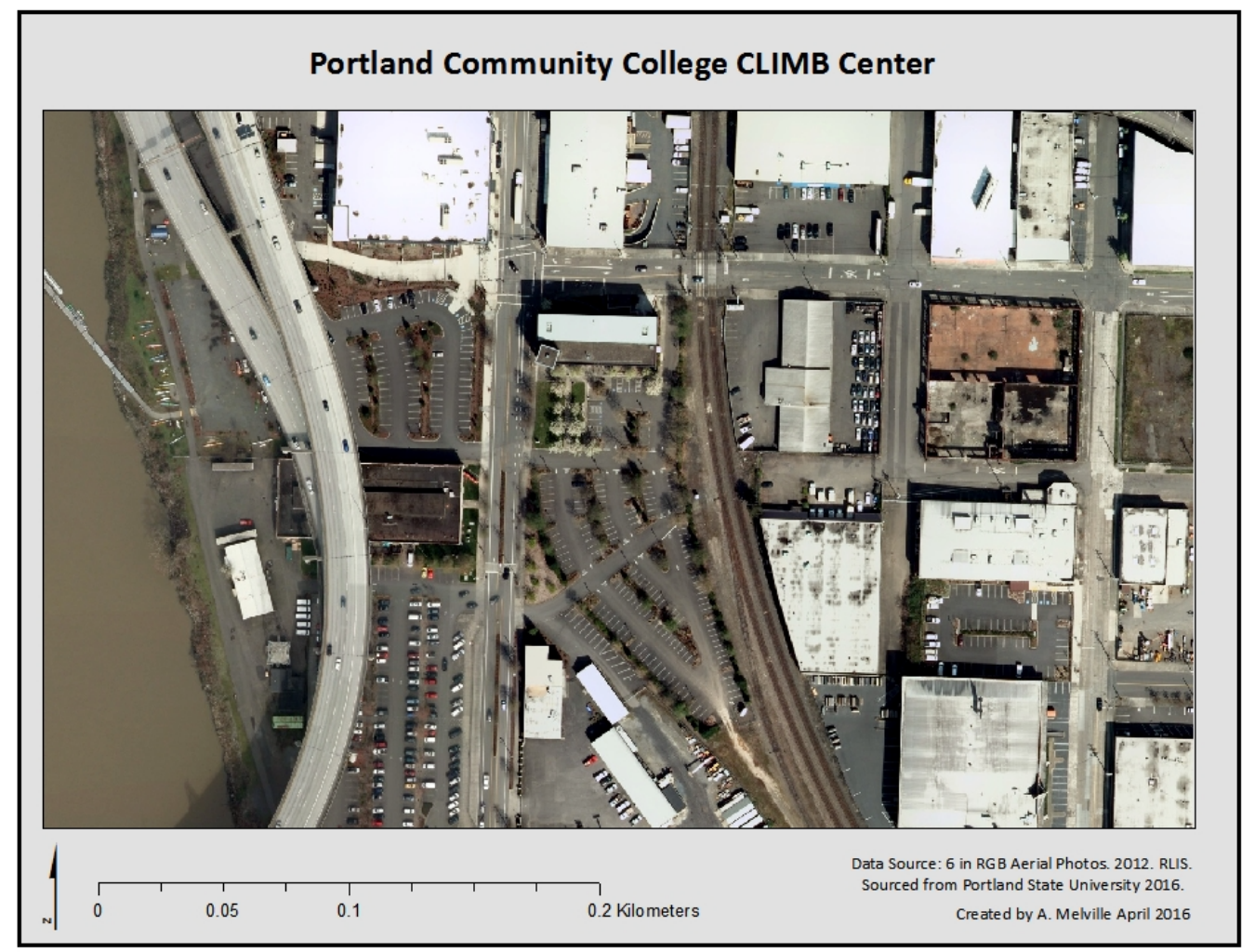

Figure 10: map showing CLIMB and its surroundings

'Duplo In' stormwater samples were collected from parking lot runoff flowing into the bioswale when possible, otherwise they were collected from the pooled stormwater at the inflow, which can be seen in Figure 11. Sample locations for soil and

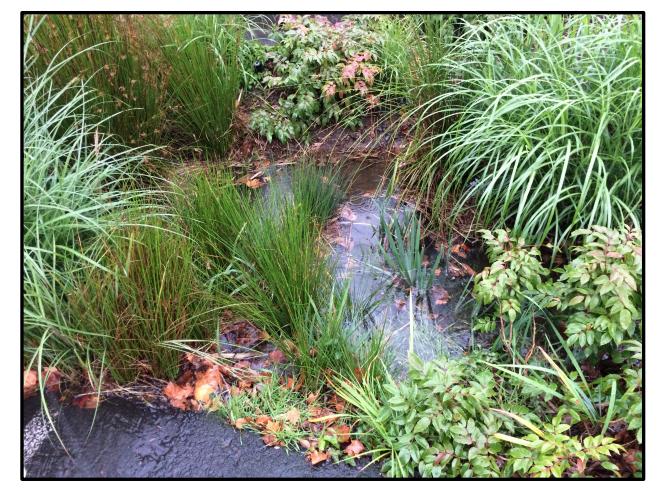

Figure 11: Photo of Duplo In stormwater pool stormwater in relation to the treatment area and flow direction is illustrated in Figure 12. 
Portland Community College

CLIMB Stormwater Facilities

Mycoremediation Study Area

Note: The southern

Soil sample in Moto

Мото

was used for S1 and S2

but was replaced by the

stormwater sample location

in the middle of the

pool for 54.

Where soil sample

locations are not

marked, the

stormiwater sample

location noted was

the site for both

stormwater and soil.

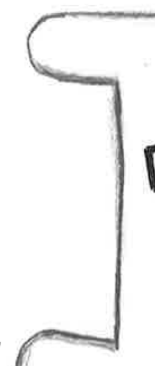

DuPLO

$10 M$

Study Area
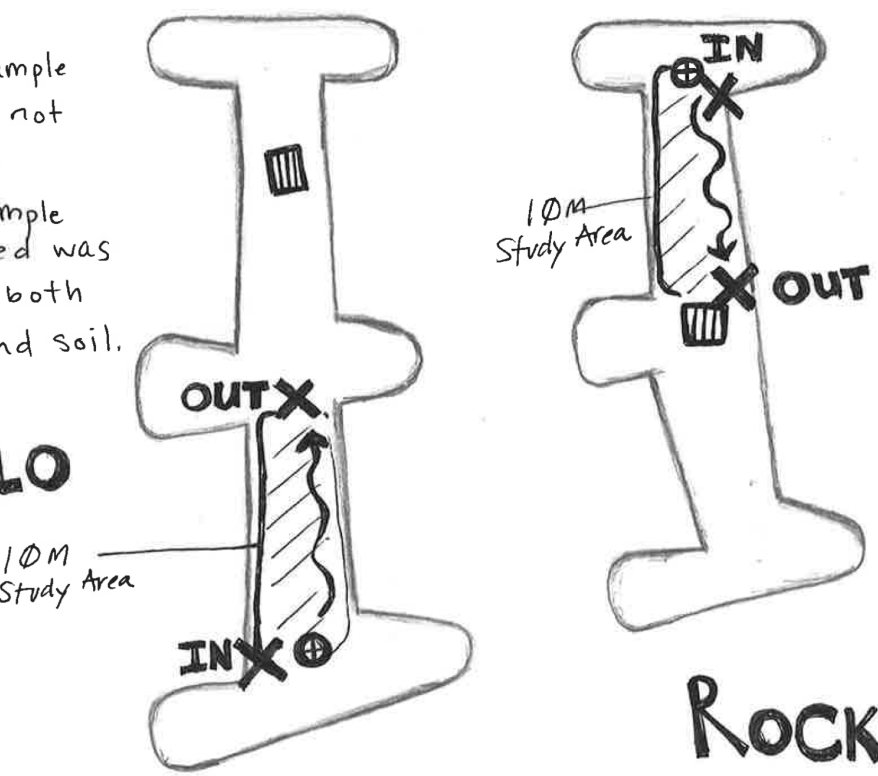

Rocky

* Stormwater sample location

- Soil sample location

(III) Overflow drain grate

$\sim$ Flow direction

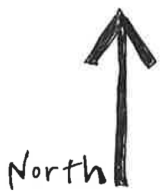

* not to scale

Melville 2016 Portland State University

Figure 12: Portland Community College CLIMB study area sample locations and flow direction 
Rocky was positioned at a low point in the parking lot and received a relatively large amount of drainage. There was a surface level overflow pipe that stormwater drained into, located south of center and surrounded by a filter grate. Drainage flowed towards the grate on both sides, potentially allowing for two study sites. Rocky North was $10 \mathrm{~m}$ long, and Rocky South (south of the grate) was $5 \mathrm{~m}$ long.

Rocky South did not accumulate enough stormwater to facilitate sampling, hence Rocky North became the focus of this study. Rocky 'In' samples were collected from parking lot runoff flowing into the bioswale at the northeast corner. 'Out' samples were collected in the stormwater pool, pictured in Figure 13, that formed immediately downstream of the study area $10 \mathrm{~m}$ barrier before flowing into the overflow drainage.

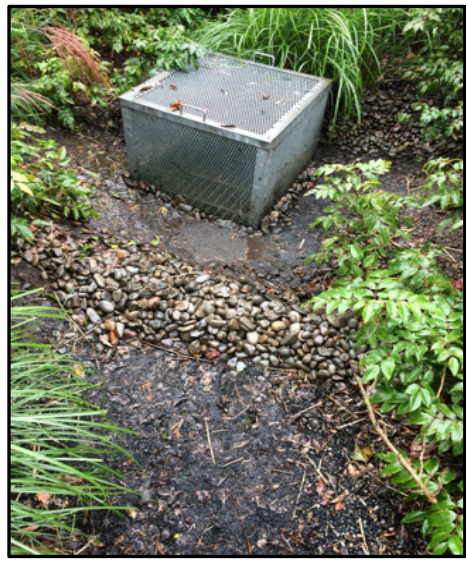

Figure 13: Rocky outflow (facing north). Samples collected from the north edge of the pool. Study area is not visible

Moto, at the north end of the parking lot, was a smaller swale that was originally intended as a clean control, but did not have overflow drainage that initial investigations and engineering plans suggested. Stormwater flowed in from the parking lot and through an access point channeled through the south-side curb, draining a low spot on the road where stormwater pooled. Litter accumulated in the bioswale (Figure 14). The Moto swale, measured from where the downward slope of 
the swale begins, was $14 \mathrm{~m}$ long. Samples were still collected but the location of the sample sites shifted as site understanding increased. Due to these issues Moto did not serve as a control, but instead offered additional data on soil and

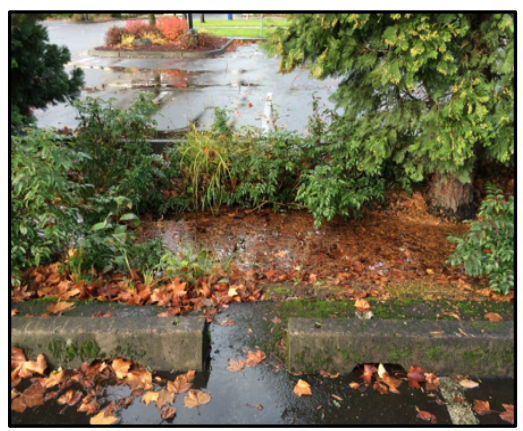
stormwater metal levels for an infiltration based

Figure 14: Moto full of stormwater and litter (midway facing west)

system without engineered overflow or

treatment. 


\section{Chapter 3: Methods}

The mycorrhizal fungi blend used as a treatment was PermaMatrix ${ }^{\circledR}$ BSP Foundation, a shelf-stable, general purpose biotic soil amendment produced locally by PermaMatrix ${ }^{\circledR}$ Inc. The treatment was applied to these relatively old bioswales, aged 20 years, which had established vegetation, large amounts of gravel, and compacted soil. Two bioswales (Rocky and Duplo) received treatment of a stormwater filter media called Earthlite ${ }^{\mathrm{T}}$, produced by Sunmark Environmental. The Earthlite $^{\mathrm{TM}}$ stormwater filter blend was composed of rinsed Douglas fir biochar, reed sedge peat pellets, and shale. In Duplo, PermaMatrix ${ }^{\circledR}$ BSP Foundation was applied as a top layer over the bioswale soil surface prior to the application of the Earthlite ${ }^{\text {TM }}$ stormwater filter media in order to test the ability of mycoremediation/ mycofiltration to enhance the function of Earthlite ${ }^{\mathrm{TM}}$ stormwater filter media in a bioswale with established vegetation, without tilling or adding mulch.

The manufacturer recommended a top layer application of PermaMatrix ${ }^{\circledR}$ BSP Foundation when there is established vegetation that is best left undisturbed. Tilling the PermaMatrix ${ }^{\circledR}$ in was recommended if treatment were applied to a new installation with no established vegetation. Thus treatment media application is both flexible and scalable.

Duplo received both the Earthlite ${ }^{\text {TM }}$ stormwater filter blend and the mycorrhizal fungi blend; Rocky received just the Earthlite ${ }^{\mathrm{Tm}}$ stormwater filter blend. Stormwater samples were tested for zinc, copper, lead, iron, total phosphorus, chemical oxygen demand, and pH. Bioswale soil was analyzed for nutrients and a 
variety of metrics including zinc, copper, iron, $\mathrm{pH}$, phosphorus, nitrate, ammonia, organic matter content, and texture. The study focused on zinc, copper, and phosphorus.

Tracer dye was used to quantify residence time at two different precipitation events. Stormwater grab samples were collected from parking lot runoff flowing into the bioswales, then again after $10 \mathrm{~m}$ for three different precipitation events. Precipitation was monitored through a nearby United States Geologic Survey (USGS) rain gauge, situated five blocks from the study site. Soil samples were collected before the treatment installation, mid-study, and at the completion of the study.

\section{Treatment}

The mycorrhizal blend being tested, PermaMatrix ${ }^{\circledR}$ BSP Foundation mixed purpose biotic soil amendment was originally produced by Sunmark Environmental, and then by PermaMatrix ${ }^{\circledR}$ Inc. The PermaMatrix ${ }^{\circledR}$ blend consisted of endo and ectomycorrhizal fungi, bacteria, basalt, biochar, and reed sedge peat (Table 1). The mycorrhizal fungi blend was formulated by Fungi Perfecti for PermaMatrix ${ }^{\circledR}$.

The active ingredients listed made up 3.5\% of the formula. The inactive base ingredients, basalt, reed sedge peat, and rinsed Douglas fir biochar, constituted the remaining 96.5\% of the formula. The mycorrhizal blend in PermaMatrix ${ }^{\circledR}$ BSP Foundation used both endomycorrhizal and ectomycorrhizal fungi. The endomycorrhizal fungi species were all in the Glomus family, and included: Glomus intraradices (1.1 propagules/gm); Glomus mosseae (1.1 propagules/gm); Glomus aggregatum (1.1 propagules/gm); and Glomus etunicatum (1.1 propagules/gm). 
The ectomycorrhizal species present were dominated by Pisolithus tinctorius and the Rhizopogon family and included: Pisolithus tinctorius $(3,964$ propagules/ gm); Rhizopogon villosullus (110 propagules/gm); Rhizopogon luteolus (110 propagules/gm); Rhizopogon amylopogon (110 propagules/gm); Rhizopogon fulvigleba (110 propagules/gm); Scleroderma cepa (220 propagules/gm); and Scleroderma citrine (220 propagules/gm).

In addition to mycorrhizal fungi, the blend included the following nitrogen fixers measured by colony forming units (CFU): Azospirillum lipoferum $\left(1.10 \times 10^{12}\right.$ CFU/g); and Azospirillum brasilense (1.10×1012 CFU/g). Bacterial biochemical decomposers were also present, including: Bacillus subtilis $\left(2.57 \times 10^{12} \mathrm{CFU} / \mathrm{g}\right)$; Bacillus licheniformus $\left(2.06 \times 10^{12} \mathrm{CFU} / \mathrm{g}\right)$; and Bacillus amyloliquefaciens $\left(5.15 \times 10^{11}\right.$ $\mathrm{CFU} / \mathrm{g})$.

The stormwater filter blend Earthlite ${ }^{\mathrm{T} M}$, made by Sunmark Environmental, was made up of rinsed Douglas fir biochar, large size reed sedge peat pellets, and porous shale aggregate from ES Filter. The blend was a ratio of $20 \%$ porous shale aggregate, $75.5 \%$ rinsed Douglas fir biochar, and $4.5 \%$ reed sedge peat pellets. The maximum water holding capacity for the Earthlite ${ }^{\mathrm{TM}}$ stormwater filter blend was $\geq$ $35 \%$ per volume, and the air content at maximum water capacity was $\geq 10 \%$ per volume.

\section{Tracer Dye Study}

Biodegradable tracer dye was used to determine mixing and residence time in the bioswales. Dye was dropped at parking lot level just before the 'In' locations 
used for stormwater sampling in Rocky and Duplo. The mixing of the dye was observed and rated. Additionally, the time it took for the dye to reach and pass through the $10 \mathrm{~m}$ rock barrier was recorded.

\section{Soil samples}

Metrics for soil testing included copper, zinc, nitrate, organic matter content, $\mathrm{pH}$, and texture (sand/silt/clay ratio). The texture analysis and the organic matter content were completed at the Geography Soils Lab at Portland State University. Soiltest Farm Consultants, Inc. tested soil samples for the remaining soil parameters, nutrients and metals, $\mathrm{pH}$, cation exchange capacity, ammonia, nitrate, phosphorus, potassium, manganese, calcium, boron, magnesium, iron, zinc, and copper. Full results are organized by sample event and by bioswale in Appendix A, and lab reports with results per bioswale for each sample event are in Appendix B.

Soil samples were collected before the installation of the treatment, midstudy, and after the collection of the last stormwater sample. All soil samples were a composite of three samples collected from the top $10 \mathrm{~cm}$ of the bioswale soil. This was sometimes challenging given the gravelly nature of some of the soils. Care was taken to clear all test media from the soil surface when samples were collected after installation of the treatment media so as to not contaminate samples or skew the results. All soil samples were chilled upon collection and refrigerated until they were processed.

In order to compare the similarity or differences among the bioswale soils, samples were assessed for field moisture, organic matter content, and texture in the 
Portland State Geography Department Soil Lab. Organic matter and field moisture was tested using the Natural Resource and Conservation Soil Survey Field and Laboratory Method 5.1 (2014). To assess field moisture, the soil samples were measured into weighed crucibles, weighed, dried in the drying oven overnight at $110^{\circ} \mathrm{C}$, then weighed again. The samples were then placed in the muffle furnace at $440{ }^{\circ} \mathrm{C}$ for a minimum of 16 hours in order to burn off all of the organic matter and assess its percentage. Samples were weighed again, in order to compute the loss on ignition (NRCS 2014). This material was then processed for the sand/silt/clay ratio using a modification on the micropipette method for particle size analysis based on Burt (2009), and Burt, Reinsch, and Miller (1993) (Lafrenz 2015).

Samples analyzed at the soil test lab were processed within one business day upon arrival at the lab after having been mailed with ice packs. Once received, the samples were dried overnight at $40^{\circ} \mathrm{C}$, filtered through a $2 \mathrm{~mm}$ sieve, then analyzed for each metric based on methods established by the Soil, Plant, and Water Reference Methods for the Western Region (Gavlak et al. 2003). The 1:1 method was used for testing pH. Organic matter was measured using the Walkley-Black (WB) Method. The tests for both ammonium and nitrate used a potassium chloride (KCl) extraction tested with the cadmium reduction method. Phosphorus was tested using the Bray method. Total zinc and total copper were tested using a nitric perchloric digest. Extractable levels of zinc and copper were determined by the DTPA method. Iron was also tested using the DTPA method. 
The first set of soil samples (S1) was collected 01 September and tested for field moisture, organic matter content and texture at Portland State University. A second round of soil samples (S2) was collected before the treatment installation on 27 September 2015. A third round of soil samples (S3) was collected at the media barrier swap 07 November 2015. The fourth and final round of soil samples (S4) was collected 24 February 2016. Soil samples S2, S3, and S4 were analyzed by the Soiltest lab.

\section{Application of Test Media}

Treatment was applied 11 October 2015 and was allowed to establish before stormwater testing occurred. Duplo (Figure 15) was used to test the effect of the application of PermaMatrix ${ }^{\circledR}$ BSP Foundation endo/ectomycorrhizal blend to the in situ Earthlite ${ }^{\text {tw }}$ stormwater filter media. Rocky was used to test the effect of the Earthlite $^{\text {Tm }}$ stormwater filter media treatment with no biotic soil amendments.

The test media was mechanically pre-

portioned and bagged at the manufacturers facility into the amounts needed for each

$5.0 \mathrm{~m}$ segment. The treatment amount needed was calculated by determining the amount needed for a surface area $1.0 \mathrm{~m}$ wide, $10.0 \mathrm{~m}$ long, and $0.025 \mathrm{~m}$ deep. Each $10 \mathrm{~m}$

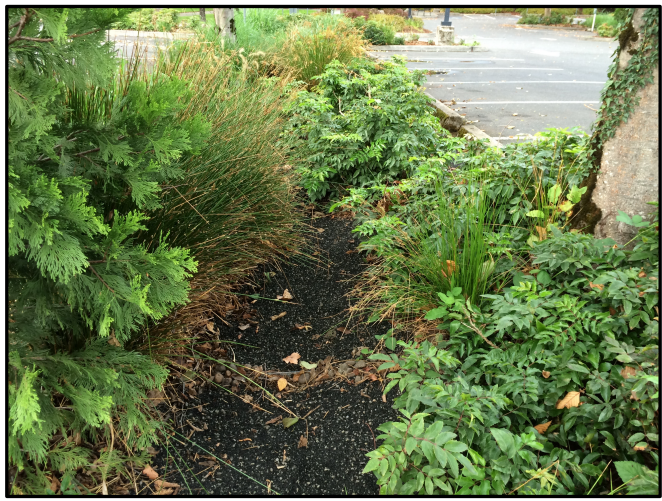

Figure 15: Duplo with treatment on installation day study area segment used $0.25 \mathrm{~m}^{3}$ of Earthlite $^{\text {tw }}$ stormwater filter media ( 9 cubic feet). Three bags equaled 0.13 cubic 
meters of Earthlite $\mathrm{f}^{\mathrm{Tm}}$, the amount needed for each $5.0 \mathrm{~m}$ segment. The volume of six bags was 0.25 meters cubed, the amount needed for a $10.0 \mathrm{~m}$ segment.

The media was installed in the study area bioswales by spreading it into an even layer by hand. In Duplo, the PermaMatrix ${ }^{\circledR}$ BSP Foundation was spread out first, then the Earthlite ${ }^{\text {tm }}$ stormwater filter blend was applied over top. In Rocky, Earthlite $^{\text {tw }}$ stormwater filter blend was applied directly to the soil surface in an even layer. Test media was allowed to establish for 63 days before any stormwater sampling was done. The bioswales were irrigated three days a week (Monday, Wednesday, and Friday) through the summer season ending 01 November, hence, there was consistent moisture during the establishment phase. The built-in sprinkler system had the same design and spacing in both bioswales.

Metal flashing (Figure 16) was originally used as a barrier to delineate the study areas in the bioswales. The material was thought to be be resistant to leaching and deterioration. This came into question after learning that flashing is often hot dipped in a zinc coating that could possibly leach. Therefore, the flashing was removed. A round of soil testing was done after the removal and before installing the new barrier in order to assess the influence of the flashing. This soil sample event (S3) took place 07 November with two of the three composite samples being sourced from the soil

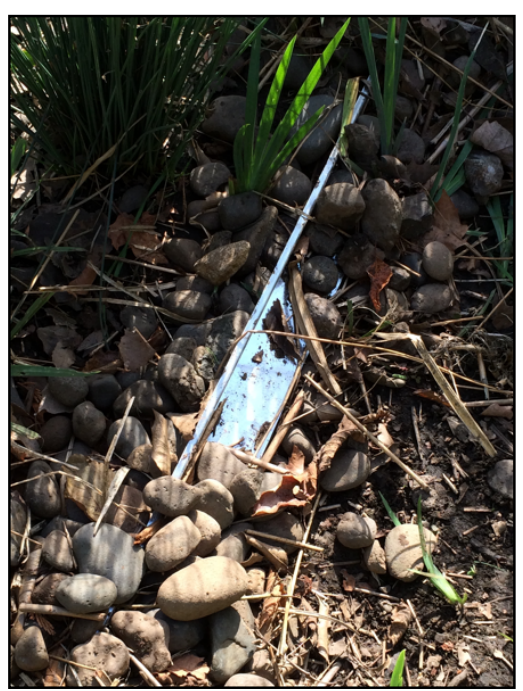

Figure 16: Metal flashing 
directly below the flashing, and one sourced from between 5-10 cm downstream. The flashing was in situ 28 days.

The flashing was replaced with $1 / 4$ to $3 / 4$ inch clean river rock sourced from Mt. Scott Fuel, which achieved a more effective barrier for containing the test media. After several of the larger precipitation events (before the barrier swap), there were issues with test media flowing over the flashing in Rocky and collecting around the drain grate. Test media was returned to the study area by hand. It is approximated that most of the spillover media was captured and returned to the delineated study area. Installation of the river rock barrier stopped the overflow of the test material while still allowing for good filtration. The stormwater could be seen flowing through the rock barrier and then pooling immediately downstream of the rock barrier, which provided a good area to collect stormwater "Out" samples after $10 \mathrm{~m}$ of treatment.

\section{Stormwater Samples}

Stormwater samples were collected for three precipitation events between December 2015 and February 2016. Grab samples were collected in sterile bottles prepped by the lab with chemical preservatives appropriate for each metric being sampled. Samples were chilled, hand delivered, and analyzed by Pixis Labs in Portland, Oregon. An Extec Instruments D0700 mobile unit was also used to test for $\mathrm{pH}$ and temperature onsite as stormwater samples were collected.

Water quality metrics for stormwater included: zinc, copper, iron, lead, chemical oxygen demand (COD), total phosphorus, and pH. Pixis Labs used the SM 
4500-P-B5d Method for testing total phosphorus. Chemical oxygen demand was analyzed using the EPA 410.4 Method. Zinc, copper, lead, and iron were all tested using the EPA 200.7 Method.

Samples were collected using a glass volumetric container that was rinsed with deionized water, then allowed to fill with stormwater samples and be emptied, thus flushing the collection container three times before samples were collected for transfer into the sterile lab sample bottles. Samples were collected with care so as not to stir up debris. Rinse water was collected in a bucket and emptied after sample collection was finished. 


\section{Chapter 4: Results}

The results for the four soil sample events are labeled S1-S4, in chronological order of sampling. The three stormwater sample events are labeled W1-W3, and the two tracer dye studies are T1 and T2. Rain gauge data for each precipitation event are included with the results. Table 2 shows a timeline of significant events for the study, including treatment installation, soil sample dates, stormwater sample dates, and dates for the tracer dye studies, paired with cumulative precipitation levels starting from the date of the treatment media installation, and precipitation rates for the sample hour and three hours prior.

\section{Tracer Dye Study Results}

The first tracer dye study was done 06 December 2015 in order to quantify stormwater residence time. Thirty milliliters of Kingscote Chemicals Bright biodegradable tracer dye was released at 8:37 and took 20 minutes to reach the $10 \mathrm{~m}$ barrier. There had been $0.28 \mathrm{~cm}(0.11 \mathrm{in})$ of precipitation in the three hours prior, and $0.05 \mathrm{~cm}(0.02 \mathrm{in})$ during the hour the dye was released. It took 34 minutes for the dye to reach the $15 \mathrm{~m}$ barrier and 77 minutes for the dye to traverse the bioswale reaching the $20 \mathrm{~m}$ point. It stopped raining approximately twenty minutes after dropping the dye so the water started moving more slowly through the bioswales. This limited the assessment to just Duplo.

Six days later, on 12 December 2015 a second tracer dye study was conducted following water quality sampling. There had been $0.08 \mathrm{~cm}(0.32 \mathrm{in})$ of precipitation in the three hours prior, and $0.5 \mathrm{~cm}(0.18 \mathrm{in})$ during the sample hour. 


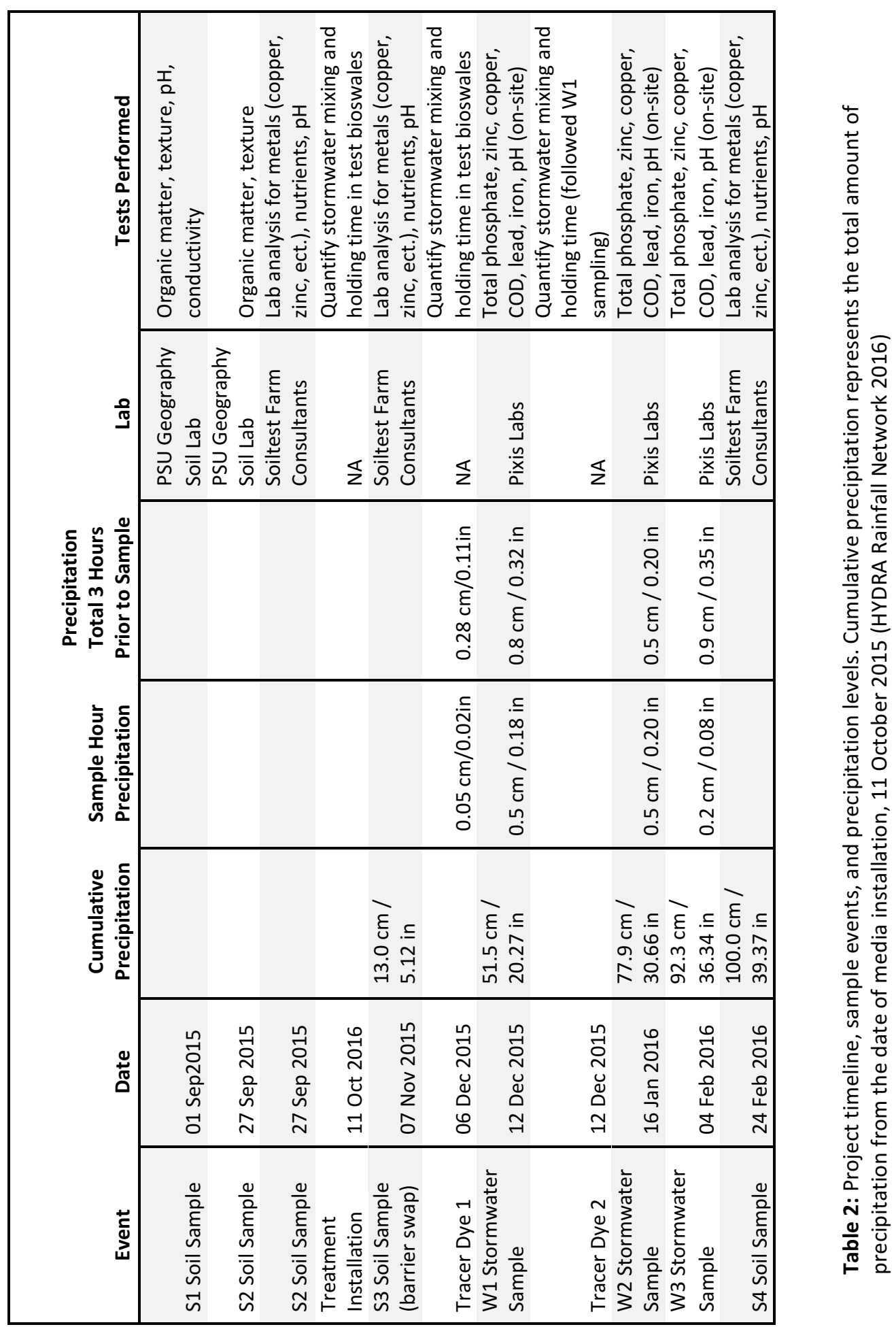


Thirty milliliters of tracer dye was released into Duplo at 10:35; it reached the $10 \mathrm{~m}$ barrier in 6 minutes and the $15 \mathrm{~m}$ barrier in 9 minutes. It took up to one minute for stormwater to move through the barrier so the residence time for this precipitation event is believed to be approximately 7 minutes for the dye to get through the $10 \mathrm{~m}$ barrier where sampling would occur. The tracer dye mixed well (Figure 17), filling the width of the bioswale channel. Note that residence times (Table 3) for the tracer dye study reflect the amount of time needed for stormwater to reach the $10 \mathrm{~m}$ barrier, not including the time taken to move through the rock barrier into the sample area. This is to ensure that the residence time communicated reflects the minimum amount of time

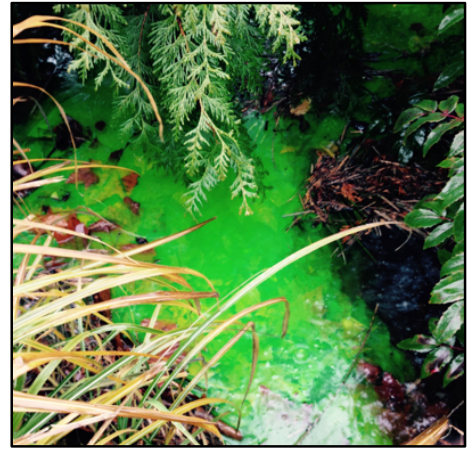

Figure 17: Tracer dye study 12 December 2015 showing full dispersal and good mixing that stormwater has had residence in the study area. It took 14 minutes for the dye laced stormwater to reach the drain grate and 25 minutes after initial discharge, there was still dye throughout the bioswale.

\begin{tabular}{|c|l|l|l|l|}
\hline \multicolumn{2}{|c|}{ Tracer Dye Study } & \multicolumn{3}{l|}{} \\
Date & Bioswale & \multicolumn{1}{l|}{ Time } & \multicolumn{1}{l|}{ Mixing } & Notes \\
\hline 06 Dec & Duplo & $20 \mathrm{~min}$ & very good & Stopped raining $~ 15 / 20$ minutes after dropping dye \\
12 Dec & Duplo & $6 \mathrm{~min}$ & good & Dye dropped after collection of stormwater samples \\
12 Dec & Rocky & $1.5 \mathrm{~min}$ & good & Dye cleared out of Rocky 9 minutes after drop \\
\hline
\end{tabular}

Table 3: Tracer dye study results

Thirty milliliters of tracer dye was dropped into stormwater flowing into Rocky at 10:38. In Rocky the stormwater was moving faster taking 90 seconds to reach the $10 \mathrm{~m}$ barrier and approximately two minutes for the stormwater to travel 
through the barrier into the sample area. The dye was completely flushed out of the northern half of the swale within nine minutes. By 13:35 all of the dye had been flushed out of both bioswales.

\section{Soil Sample Results}

\section{Pre-Installation Soil Samples (S1)}

Pre-installation soil samples (labeled S1) were collected 01 September 2015 and processed at the Portland State Geography Department Soil Lab (Figure 18). These samples were processed for field moisture, organic matter, and texture (Table 4).

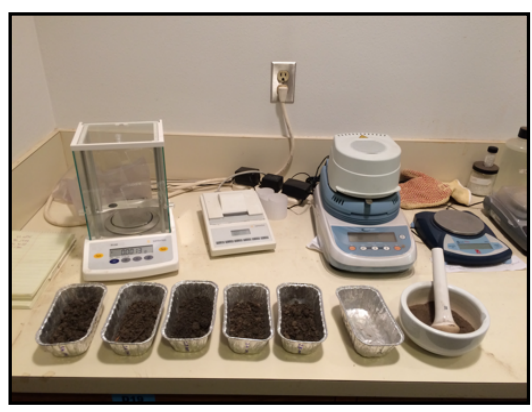

Figure 18: Samples being processed at the Portland State Geography Department Soil Lab

Soil samples for Duplo were gathered from

the inflow area and the outflow (at 20m). Duplo In had 40\% field moisture, and Duplo Out was at 30\%. Organic matter was 19\% at Duplo In and Duplo Out. Clay percentage for Duplo In was 5\%, and 4\% for Duplo Out. Duplo In was $22 \%$ sand, and Duplo Out had 30\%. Duplo In measured at 74\% silt, while Duplo Out had 65\% silt. As such, there is little difference between soil samples at either end of this bioswale.

\begin{tabular}{|l|r|r|r|r|r|}
\hline & Field Moisture \% & Organic Matter \% & Clay \% & Sand \% & Silt \% \\
\hline Moto North & 35 & 15 & 8 & 25 & 66 \\
Moto South & 36 & 20 & 6 & 28 & 66 \\
Rocky In & 23 & 20 & 6 & 27 & 67 \\
Rocky out & 30 & 15 & 6 & 31 & 63 \\
Duplo In & 40 & 19 & 5 & 21 & 74 \\
Duplo Out & 30 & 19 & 4 & 30 & 65 \\
\hline
\end{tabular}

Table 4: S1 Results for field moisture, organic matter, and texture 
Soil samples for Rocky were collected at the northern side of the bioswale and the outflow near the drain grate. Field moisture for Rocky In was $23 \%$, and was $30 \%$ for Rocky Out. Rocky In had 20\% organic matter, and Rocky Out had 15\% organic matter. Both Rocky In and Rocky Out had 6\% clay. The sand proportion was $27 \%$ for Rocky In and 31\% for Rocky Out. Rocky in was $67 \%$ silt, and Rocky Out had $63 \%$ silt. Once again, there is little difference between soil samples in this bioswale.

Soil samples for Moto were collected from the southern and northern ends of the bioswale. Field moisture for Moto North was 35\%, and 36\% for Moto South. Moto North was at $15 \%$ organic matter, and Moto South had 20\% organic matter. Clay for Moto North was 9\%, and was 6\% for Moto South. Sand for Moto North was $25 \%$, and measured at 28\% for Moto South. Moto North and Moto South were both 66\% silt. As with Duplo and Rocky, the soil samples within Moto are quite similar.

The range for field moisture in all three bioswales was between $23 \%$ and $40 \%$. Organic matter was between $15 \%$ and $20 \%$. Clay ranged from $4 \%$ to $9 \%$. Sand was between $22 \%$ and $31 \%$. The proportion of silt ranged from $63 \%$ up to $74 \%$. If Moto was not included the range would be between $15 \%$ and $20 \%$ for organic matter, and between $4 \%$ and $6 \%$ for clay. In sum, the soil samples among all three bioswales were quite similar with respect to organic matter and texture and less so with respect to field moisture (Table 4).

Pre-Installation Soil Sample No.2 (S2)

A second round of pre-installation soil samples (S2) were gathered 27 September 2015 in order to get a full lab assay before the installation of the 
treatment media. Samples were tested for a range of metrics as a part of a lab package of tests. This report includes data on soil pH, organic matter, ammonium, nitrate, phosphorus, total zinc, extractable zinc, total copper, extractable copper, and iron. The metrics of focus were zinc, copper, $\mathrm{pH}$, and phosphorus. Full results can be found in Appendix A and original lab reports are in Appendix B. A summary of results is provided for the metrics of interest to this study.

Duplo In and Out both had a pH of 5.3 (Table 5). Phosphorus for Duplo In measured at $37 \mathrm{mg} / \mathrm{kg}$, and increased at Duplo Out which measured at $113 \mathrm{mg} / \mathrm{kg}$. Total zinc at Duplo In was $197.24 \mathrm{mg} / \mathrm{kg}$, decreasing to $166.61 \mathrm{mg} / \mathrm{kg}$ at Duplo Out. Extractable zinc also decreased from $45.4 \mathrm{mg} / \mathrm{kg}$ at the In sample location to 40.6 $\mathrm{mg} / \mathrm{kg}$ at Duplo Out. Both total copper and extractable copper decrease slightly from Duplo In to Duplo Out, measuring at $45.78 \mathrm{mg} / \mathrm{kg}$ to $43.57 \mathrm{mg} / \mathrm{kg}$ and $7.9 \mathrm{mg} / \mathrm{kg}$ to $6.6 \mathrm{mg} / \mathrm{kg}$, respectively.

Rocky In had a pH of 5.7 and Rocky Out had a slightly lower pH of 5.5 (Table 6). Phosphorus at Rocky increased from the In value of $41 \mathrm{mg} / \mathrm{kg}$, to $88 \mathrm{mg} / \mathrm{kg}$ at Rocky Out. As with Duplo, total zinc decreased from Rocky In at $292.91 \mathrm{mg} / \mathrm{kg}$, to Rocky Out, at $206.88 \mathrm{mg} / \mathrm{kg}$. Extractable zinc was $66.8 \mathrm{mg} / \mathrm{kg}$ at Rocky In, and at $47.2 \mathrm{mg} / \mathrm{kg}$ was lower at the Out. Total copper was $69.77 \mathrm{mg} / \mathrm{kg}$ at Rocky In, and down to $52.33 \mathrm{mg} / \mathrm{kg}$ at Rocky Out. Unlike Duplo, extractable copper at Rocky was the same for both the In and the Out samples at $8.5 \mathrm{mg} / \mathrm{kg}$. 


\begin{tabular}{|l|l|l|r|r|}
\hline Metric & Test & Unit & Duplo In & Duplo Out \\
\hline pH & $1: 1$ & & 5.3 & 5.3 \\
Organic Matter & W.B. & $\%$ & 14 & 12 \\
Ammonium & $\mathrm{KCl} /$ Cadmium & $\mathrm{mg} / \mathrm{kg}$ & 13.8 & 24.7 \\
Nitrate & $\mathrm{KCl} /$ Cadmium & $\mathrm{mg} / \mathrm{kg}$ & 15.3 & 32.8 \\
Phosphorus & Bray & $\mathrm{mg} / \mathrm{kg}$ & 37 & 113 \\
Zinc (total) & NP-Dig 0-12 & $\mathrm{mg} / \mathrm{kg}$ & 197.24 & 166.61 \\
Zinc & DTPA & $\mathrm{mg} / \mathrm{kg}$ & 45.4 & 40.6 \\
Copper (total) & NP-Dig 0-12 & $\mathrm{mg} / \mathrm{Kg}$ & 45.78 & 43.57 \\
Copper & DTPA & $\mathrm{mg} / \mathrm{kg}$ & 7.9 & 6.6 \\
Iron & DTPA & $\mathrm{mg} / \mathrm{kg}$ & 436 & 254 \\
\hline
\end{tabular}

Table 5: Duplo lab summary, S2 samples collected 27 September 2015

\begin{tabular}{|l|l|l|r|r|}
\hline Chemical & Test & Unit & Rocky In & Rocky Out \\
\hline pH & $1: 1$ & & 5.7 & 5.5 \\
Organic Matter & W.B. & $\%$ & 24 & 13 \\
Ammonium & $\mathrm{KCl} /$ Cadmium & $\mathrm{mg} / \mathrm{kg}$ & 9.0 & 8.5 \\
Nitrate & $\mathrm{KCl} /$ Cadmium & $\mathrm{mg} / \mathrm{kg}$ & 20.6 & 23.7 \\
Phosphorus & Bray & $\mathrm{mg} / \mathrm{kg}$ & 41 & 88 \\
Zinc (total) & NP-Dig 0-12 & $\mathrm{mg} / \mathrm{kg}$ & 292.91 & 206.88 \\
Zinc & DTPA & $\mathrm{mg} / \mathrm{kg}$ & 66.8 & 47.2 \\
Copper (total) & NP-Dig 0-12 & $\mathrm{mg} / \mathrm{kg}$ & 69.77 & 52.33 \\
Copper & DTPA & $\mathrm{mg} / \mathrm{kg}$ & 8.5 & 8.5 \\
Iron & DTPA & $\mathrm{mg} / \mathrm{kg}$ & 226 & 252 \\
\hline
\end{tabular}

Table 6: Rocky lab summary, S2 samples 27 September 2015

\section{Barrier Swap Soil Samples (S3)}

In order to assess if there was any impact of using flashing, a third set of samples (S3) was collected from Duplo and Rocky during the barrier swap 07 November 2015. The cumulative amount of precipitation that had been through the system between the installation of the test media and S3 was $13.0 \mathrm{~cm}$ (5.12 in) (Table 2). Samples were collected from locations where flashing was replaced with rock. The pH for Duplo was 5.8 at Duplo In, moving slightly up to 5.9 at the $10 \mathrm{~m}$ Out, down to 5.3 at $15 \mathrm{~m}$, and up at 5.5 at $20 \mathrm{~m}$ (Table 7). Phosphorus was $53 \mathrm{mg} / \mathrm{kg}$ at the $0 \mathrm{~m}$ Duplo In, increasing to $88 \mathrm{mg} / \mathrm{kg}$ at the $10 \mathrm{~m}$ Out, lowering to $56 \mathrm{mg} / \mathrm{kg}$ at 
$15 \mathrm{~m}$, and was up to its highest level at $97 \mathrm{mg} / \mathrm{kg}$ for the $20 \mathrm{~m}$ soil sample site. Total zinc levels measured at $263.57 \mathrm{mg} / \mathrm{kg}$ for Duplo In, dropping to $209.90 \mathrm{mg} / \mathrm{kg}$ at the $10 \mathrm{~m}$ Out, then down again at $199.22 \mathrm{mg} / \mathrm{kg}$ for the $15 \mathrm{~m}$ soil sample, reducing again slightly to $194.81 \mathrm{mg} / \mathrm{kg}$ at the $20 \mathrm{~m}$ sample site. Extractable zinc levels were at 59.1 $\mathrm{mg} / \mathrm{kg}$ for Duplo In at $0 \mathrm{~m}$, reducing slightly to $58.7 \mathrm{mg} / \mathrm{kg}$ for Duplo Out at $10 \mathrm{~m}$, down to $55.6 \mathrm{mg} / \mathrm{kg}$ at $15 \mathrm{~m}$, and increasing to 60.0 at $20 \mathrm{~m}$ Duplo Out sample site. Total copper levels were $68.28 \mathrm{mg} / \mathrm{kg}$ for Duplo In at $0 \mathrm{~m}$, reducing to 43.8 at $10 \mathrm{~m}$, and $42.71 \mathrm{mg} / \mathrm{kg}$ at $15 \mathrm{~m}$, then increasing to $46.07 \mathrm{mg} / \mathrm{kg}$ at $20 \mathrm{~m}$. Extractable copper was 10.0 at Duplo In, lowering to $7.1 \mathrm{mg} / \mathrm{kg}$ at $10 \mathrm{~m}$, with another slight reduction to $6.2 \mathrm{mg} / \mathrm{kg}$ at $15 \mathrm{~m}$, increasing to $7.4 \mathrm{mg} / \mathrm{kg}$ at $20 \mathrm{~m}$.

\begin{tabular}{|c|c|c|c|c|c|c|}
\hline Metric & Test & Unit & Duplo In & $\begin{array}{l}\text { Duplo } \\
\text { Out } 10 \mathrm{~m}\end{array}$ & $\begin{array}{l}\text { Duplo } \\
\text { Out } 15 \mathrm{~m}\end{array}$ & $\begin{array}{l}\text { Duplo Out } \\
20 \mathrm{~m}\end{array}$ \\
\hline $\mathrm{pH}$ & $1: 1$ & & 5.8 & 5.9 & 5.3 & 5.5 \\
\hline Organic Matter & W.B. & $\%$ & 18 & 14 & 18 & 17 \\
\hline Ammonium & $\mathrm{KCl} /$ Cadmium & $\mathrm{mg} / \mathrm{kg}$ & 7.4 & 5.0 & 5.7 & 11.0 \\
\hline Nitrate & $\mathrm{KCl} /$ Cadmium & $\mathrm{mg} / \mathrm{kg}$ & 2.8 & 3.6 & 13.4 & 0.5 \\
\hline Phosphorus & Bray & $\mathrm{mg} / \mathrm{kg}$ & 53 & 88 & 56 & 97 \\
\hline Zinc (total) & NP-Dig 0-12 & $\mathrm{mg} / \mathrm{kg}$ & 263.57 & 209.9 & 199.22 & 194.81 \\
\hline Zinc & DTPA & $\mathrm{mg} / \mathrm{kg}$ & 59.1 & 58.7 & 55.6 & 60.0 \\
\hline Copper (total) & NP-Dig 0-12 & $\mathrm{mg} / \mathrm{Kg}$ & 68.28 & 43.8 & 42.71 & 46.07 \\
\hline Copper & DTPA & $\mathrm{mg} / \mathrm{kg}$ & 10.0 & 7.1 & 6.2 & 7.4 \\
\hline Iron & DTPA & $\mathrm{mg} / \mathrm{kg}$ & 280 & 242 & 339 & 298 \\
\hline
\end{tabular}

Table 7: Duplo lab summary, S3 samples collected 07 November 2015

\begin{tabular}{|l|l|l|r|r|}
\hline Metric & Test & Unit & Rocky In & Rocky Out \\
\hline pH & $1: 1$ & & 6.4 & 5.8 \\
Organic Matter & W.B. & $\%$ & 3 & 18 \\
Ammonium & $\mathrm{KCl} /$ Cadmium & $\mathrm{mg} / \mathrm{kg}$ & 3.7 & 6.4 \\
Nitrate & $\mathrm{KCl} /$ Cadmium & $\mathrm{mg} / \mathrm{kg}$ & 3.3 & 2.5 \\
Phosphorus & Bray & $\mathrm{mg} / \mathrm{kg}$ & 59 & 81 \\
Zinc (total) & NP-Dig 0-12 & $\mathrm{mg} / \mathrm{kg}$ & 311.72 & 267.01 \\
Zinc & DTPA & $\mathrm{mg} / \mathrm{kg}$ & 94.5 & 73.1 \\
Copper (total) & NP-Dig 0-12 & $\mathrm{mg} / \mathrm{Kg}$ & 70.03 & 56.99 \\
Copper & DTPA & $\mathrm{mg} / \mathrm{kg}$ & 15.3 & 9.2 \\
Iron & DTPA & $\mathrm{mg} / \mathrm{kg}$ & 288 & 306 \\
\hline
\end{tabular}

Table 8: Rocky lab summary, S3 samples 07 November 2015 
Rocky In had a pH of 6.4 and Rocky Out at 10 m was lower with a pH of 5.8 (Table 8). Phosphorus was $59 \mathrm{mg} / \mathrm{kg}$ at the In sample location, increasing to 81 $\mathrm{mg} / \mathrm{kg}$ at Rocky Out. Total zinc tested at $311.72 \mathrm{mg} / \mathrm{kg}$ at the In site, and was down to $267.01 \mathrm{mg} / \mathrm{kg}$ at the Out. Extractable zinc was $94.5 \mathrm{mg} / \mathrm{kg}$ at Rocky In, and down to $73.1 \mathrm{mg} / \mathrm{kg}$ at the Rocky Out soil sample site. Total copper was $70.03 \mathrm{mg} / \mathrm{kg}$ at Rocky In, and reduced to $56.99 \mathrm{mg} / \mathrm{kg}$ at Rocky Out. Extractable copper was 15.3 $\mathrm{mg} / \mathrm{kg}$ at the In site, and lowered to $9.2 \mathrm{mg} / \mathrm{kg}$ at Rocky Out.

In sum, the levels were different but the relationship between the sample locations was the same. This set of soil samples serves as a measure of cumulative zinc and copper inputs to the bioswale soils, which resulted from the combination of inputs from stormwater runoff and possible unintended inputs via the metal flashing. Moto did not have metal flashing so samples were not collected.

\section{Final Set of Soil Samples Collected (S4)}

The last set of soil samples, labeled S4, were collected 24 February 2016, concluding the study field sampling. A total of $100.0 \mathrm{~cm}$ of precipitation (39.37 in) fell between the media installation on 11 October 2015 and collection of S4 samples (Table 2). Soil samples were collected for Duplo, Rocky, and Moto. Samples for Duplo were collected from the Duplo In location, and from immediately downstream of the $10 \mathrm{~m}$ Out location. Duplo In and Out pH were both 5.9 (Table 9). Phosphorus was $57 \mathrm{mg} / \mathrm{kg}$ at the Duplo In sample site, and $67 \mathrm{mg} / \mathrm{kg}$ at the Out. As with the first set of samples for this metric (S2), phosphorus increased but by a much smaller 
magnitude. Total zinc measured at $193.84 \mathrm{mg} / \mathrm{kg}$ at Duplo In soil sample site, reducing to $161.09 \mathrm{mg} / \mathrm{kg}$ at the $10 \mathrm{~m}$ Out site. Extractable zinc was $34.3 \mathrm{mg} / \mathrm{kg}$ at Duplo In, lowering to $30.2 \mathrm{mg} / \mathrm{kg}$ at Duplo Out. Total copper measured at 57.98 $\mathrm{mg} / \mathrm{kg}$ for Duplo In, dropping down to $38.07 \mathrm{mg} / \mathrm{kg}$ at Duplo Out. Extractable copper for the In site was $9.6 \mathrm{mg} / \mathrm{kg}$, lowering to $4.8 \mathrm{mg} / \mathrm{kg}$ at the Duplo Out soil sample site.

The $\mathrm{pH}$ for Rocky In was 5.9, dropping slightly to 5.8 for Rocky Out at $10 \mathrm{~m}$ (Table 10). Phosphorus was $45 \mathrm{mg} / \mathrm{kg}$ at the In, increasing to $73 \mathrm{mg} / \mathrm{kg}$ at the Rocky Out sample location. Total zinc was $284.11 \mathrm{mg} / \mathrm{kg}$ at the In site, lowering to 193.04 $\mathrm{mg} / \mathrm{kg}$ at the Out site. Extractable zinc measured at $82.0 \mathrm{mg} / \mathrm{kg}$ for the Rocky In soil sample location, and was reduced to $65.7 \mathrm{mg} / \mathrm{kg}$ at Rocky Out. Total copper was $74.38 \mathrm{mg} / \mathrm{kg}$ at the In, and lowered to $41.60 \mathrm{mg} / \mathrm{kg}$ at Rocky Out. Extractable copper measured at $11.7 \mathrm{mg} / \mathrm{kg}$ for Rocky In, and was again lowered measuring at 7.3 $\mathrm{mg} / \mathrm{kg}$ at the Rocky Out sample site.

Moto In samples were collected from the stormwater inflow location, and Moto Pool samples were collected from the middle of the bioswale where the stormwater collects into a standing pool. Moto In $\mathrm{pH}$ was 6.2 and the pool measured slightly higher at 6.4 (Table 11). Phosphorus at Moto In measured at $85 \mathrm{mg} / \mathrm{kg}$, and was up to $90 \mathrm{mg} / \mathrm{kg}$ at the Moto Pool site. Total zinc measured at $241.45 \mathrm{mg} / \mathrm{kg}$ at the Moto In soil sample site, increasing to $331.05 \mathrm{mg} / \mathrm{kg}$ in the Moto Pool site. Extractable zinc was $43.0 \mathrm{mg} / \mathrm{kg}$ for Moto In, increasing up to $71.4 \mathrm{mg} / \mathrm{kg}$ for the Moto Pool. Total copper measured at $56.88 \mathrm{mg} / \mathrm{kg}$ at the Moto In site, and was 
slightly lower at $53.93 \mathrm{mg} / \mathrm{kg}$ in the Moto Pool site. Extractable copper was 8.4 $\mathrm{mg} / \mathrm{kg}$ at the In, and again was lower at the Moto Pool sample at $6.6 \mathrm{mg} / \mathrm{kg}$.

\begin{tabular}{|l|l|l|r|r|}
\hline Metric & Test & Unit & Duplo In & Duplo Out \\
\hline pH & $1: 1$ & & 5.9 & 5.9 \\
Organic Matter & W.B. & $\%$ & 17 & 12 \\
Ammonium & $\mathrm{KCl} /$ Cadmium & $\mathrm{mg} / \mathrm{kg}$ & 6.5 & 6.0 \\
Nitrate & $\mathrm{KCl} /$ Cadmium & $\mathrm{Lbs} / \mathrm{Acre}$ & 1.4 & 2.0 \\
Phosphorus & Bray & $\mathrm{mg} / \mathrm{kg}$ & 57 & 67 \\
Zinc (total) & NP-Dig 0-12 & $\mathrm{mg} / \mathrm{kg}$ & 193.84 & 161.09 \\
Zinc & DTPA & $\mathrm{mg} / \mathrm{kg}$ & 34.3 & 30.2 \\
Copper (total) & NP-Dig 0-12 & $\mathrm{mg} / \mathrm{Kg}$ & 57.98 & 38.07 \\
Copper & DTPA & $\mathrm{mg} / \mathrm{kg}$ & 9.6 & 4.8 \\
Iron & DTPA & $\mathrm{mg} / \mathrm{kg}$ & 407 & 264 \\
\hline
\end{tabular}

Table 9: Duplo lab summary, S4 samples collected 24 February 2016

\begin{tabular}{|l|l|l|r|r|}
\hline Metric & Test & Unit & \multicolumn{1}{l|}{ Rocky In } & \multicolumn{1}{l|}{ Rocky Out } \\
\hline pH & $1: 1$ & & 5.9 & 5.8 \\
Organic Matter & W.B. & $\%$ & 25 & 19 \\
Ammonium & $\mathrm{KCl} /$ Cadmium & $\mathrm{mg} / \mathrm{kg}$ & 9.3 & 1.6 \\
Nitrate & $\mathrm{KCl} /$ Cadmium & $\mathrm{mg} / \mathrm{kg}$ & 2.1 & 3.8 \\
Phosphorus & $\mathrm{Bray}$ & $\mathrm{mg} / \mathrm{kg}$ & 45 & 73 \\
Zinc (total) & $\mathrm{NP}-\mathrm{Dig} 0-12$ & $\mathrm{mg} / \mathrm{kg}$ & 284.11 & 193.04 \\
Zinc & $\mathrm{DTPA}$ & $\mathrm{mg} / \mathrm{kg}$ & 82.0 & 65.7 \\
Copper (total) & $\mathrm{NP}-\mathrm{Dig} 0-12$ & $\mathrm{mg} / \mathrm{kg}$ & 74.38 & 41.60 \\
Copper & $\mathrm{DTPA}$ & $\mathrm{mg} / \mathrm{kg}$ & 11.7 & 7.3 \\
Iron & $\mathrm{DTPA}$ & $\mathrm{mg} / \mathrm{kg}$ & 353 & 416 \\
\hline
\end{tabular}

Table 10: Rocky lab summary, S4 samples collected 24 February 2016

\begin{tabular}{|l|l|l|r|r|}
\hline Metric & Test & Unit & Moto In & Moto Pool \\
\hline pH & $1: 1$ & & 6.2 & 6.4 \\
Organic Matter & W.B. & $\%$ & 11 & 13 \\
Ammonium & $\mathrm{KCl} /$ Cadmium & $\mathrm{mg} / \mathrm{kg}$ & 5.9 & 9.3 \\
Nitrate & $\mathrm{KCl} /$ Cadmium & $\mathrm{Lbs} / \mathrm{Acre}$ & 1.0 & 1.5 \\
Phosphorus & $\mathrm{Bray}$ & $\mathrm{mg} / \mathrm{kg}$ & 85 & 90 \\
Zinc (total) & $\mathrm{NP}-\mathrm{Dig} 0-12$ & $\mathrm{mg} / \mathrm{kg}$ & 241.45 & 331.05 \\
Zinc & DTPA & $\mathrm{mg} / \mathrm{kg}$ & 43.0 & 71.4 \\
Copper (total) & NP-Dig 0-12 & $\mathrm{mg} / \mathrm{Kg}$ & 56.88 & 53.93 \\
Copper & DTPA & $\mathrm{mg} / \mathrm{kg}$ & 8.4 & 6.6 \\
Iron & DTPA & $\mathrm{mg} / \mathrm{kg}$ & 132 & 163 \\
\hline
\end{tabular}

Table 11: Moto lab summary, S4 samples collected 24 February 2016 
In summary, Duplo showed consistent reductions in the metrics of interest, especially when related to S2 levels measured before the installation of the treatment. The reductions experienced by Duplo, who received a treatment of PermaMatrix ${ }^{\circledR}$ BSP Foundation blend, was in contrast to Rocky who received an application of Earthlite stormwater filter media only, and experienced increases in some of the metrics of interest. Results for Duplo and Rocky compared over time are in Table 12 and Table 13. Percent change measured in soil metrics over the course of the study period (S2 to S4) are in Table 14 for Duplo and Table 15 for Rocky. Percent change between Duplo and Rocky are compared in Table 16.

\begin{tabular}{|c|c|c|c|c|c|c|c|c|}
\hline & & & 27 Sep & 27 Sep & 07 Nov & $07 \mathrm{Nov}$ & 24 Feb & 24 Feb \\
\hline Metric & Test & Unit & $\begin{array}{l}\text { Duplo } \\
\text { In }\end{array}$ & $\begin{array}{l}\text { Duplo } \\
\text { Out }\end{array}$ & $\begin{array}{l}\text { Duplo } \\
\text { In }\end{array}$ & $\begin{array}{l}\text { Duplo } \\
\text { Out }\end{array}$ & $\begin{array}{l}\text { Duplo } \\
\text { In }\end{array}$ & $\begin{array}{l}\text { Duplo } \\
\text { Out }\end{array}$ \\
\hline $\mathrm{pH}$ & $1: 1$ & & 5.3 & 5.3 & 5.8 & 5.9 & 5.9 & 5.9 \\
\hline Organic Matter & W.B. & $\%$ & 14 & 12 & 18 & 14 & 17 & 12 \\
\hline Ammonium & $\mathrm{KCl}$ & $\mathrm{mg} / \mathrm{kg}$ & 13.8 & 24.7 & 7.4 & 5.0 & 6.5 & 6.0 \\
\hline Nitrate & $\mathrm{KCl}$ & $\mathrm{mg} / \mathrm{kg}$ & 15.3 & 32.8 & 2.8 & 3.6 & 1.4 & 2.0 \\
\hline Phosphorus & Bray & $\mathrm{mg} / \mathrm{kg}$ & 37 & 113 & 53 & 88 & 57 & 67 \\
\hline Zinc (total) & NP-Dig 0-12 & $\mathrm{mg} / \mathrm{kg}$ & 197.24 & 166.61 & 263.57 & 209.90 & 193.84 & 161.09 \\
\hline Zinc & DTPA & $\mathrm{mg} / \mathrm{kg}$ & 45.4 & 40.6 & 59.1 & 58.7 & 34.3 & 30.2 \\
\hline Copper (total) & NP-Dig 0-12 & $\mathrm{mg} / \mathrm{Kg}$ & 45.78 & 43.57 & 68.28 & 43.8 & 57.98 & 38.07 \\
\hline Copper & DTPA & $\mathrm{mg} / \mathrm{kg}$ & 7.9 & 6.6 & 10.0 & 7.1 & 9.6 & 4.8 \\
\hline Iron & DTPA & $\mathrm{mg} / \mathrm{kg}$ & 436 & 254 & 280 & 242 & 407 & 264 \\
\hline
\end{tabular}

Table 12: Soil results for Duplo before and after treatment for S2, S3, and S4 sample events

\begin{tabular}{|c|c|c|c|c|c|c|c|}
\hline & & 27 Sep & 27 Sep & 07 Nov & 07 Nov & $24 \mathrm{Feb}$ & $24 \mathrm{Feb}$ \\
\hline Chemical & Unit & Rocky In & Rocky Out & Rocky In & $\begin{array}{l}\text { Rocky } \\
\text { Out }\end{array}$ & $\begin{array}{l}\text { Rocky } \\
\text { In }\end{array}$ & $\begin{array}{l}\text { Rocky } \\
\text { Out }\end{array}$ \\
\hline $\mathrm{pH}$ & & 5.7 & 5.5 & 6.4 & 5.8 & 5.9 & 5.8 \\
\hline Organic Matter & $\%$ & 23.5 & 12.9 & 2.5 & 17.9 & 24.9 & 18.9 \\
\hline Ammonium & $\mathrm{mg} / \mathrm{kg}$ & 9.0 & 8.5 & 3.7 & 6.4 & 9.3 & 1.6 \\
\hline Nitrate & $\mathrm{mg} / \mathrm{kg}$ & 20.6 & 23.7 & 3.3 & 2.5 & 2.1 & 3.8 \\
\hline Phosphorus & $\mathrm{mg} / \mathrm{kg}$ & 41 & 88 & 59 & 81 & 45 & 73 \\
\hline Zinc (total) & $\mathrm{mg} / \mathrm{kg}$ & 292.91 & 206.88 & 311.72 & 267.01 & 284.11 & 193.04 \\
\hline Zinc & $\mathrm{mg} / \mathrm{kg}$ & 66.8 & 47.2 & 94.5 & 73.1 & 82.0 & 65.7 \\
\hline Copper (total) & $\mathrm{mg} / \mathrm{Kg}$ & 69.77 & 52.33 & 70.03 & 56.99 & 74.38 & 41.60 \\
\hline Copper & $\mathrm{mg} / \mathrm{kg}$ & 8.5 & 8.5 & 15.3 & 9.2 & 11.7 & 7.3 \\
\hline Iron & $\mathrm{mg} / \mathrm{kg}$ & 226 & 252 & 288 & 306 & 353 & 416 \\
\hline
\end{tabular}

Table 13: Rocky soil lab results compared over time 


\begin{tabular}{|c|c|c|c|c|c|c|c|c|}
\hline \multicolumn{3}{|c|}{$\begin{array}{l}\text { DUPLO - Treatment } \\
\text { Bioswale }\end{array}$} & $\begin{array}{l}27 \text { Sep } \\
\text { (S2) }\end{array}$ & $\begin{array}{l}27 \text { Sep } \\
(\mathrm{S} 2)\end{array}$ & $\begin{array}{l}24 \mathrm{Feb} \\
(\mathrm{S} 4)\end{array}$ & $\begin{array}{l}24 \text { Feb } \\
(\mathrm{S} 4)\end{array}$ & S2 - S4 & S2 - S4 \\
\hline Metric & Test & Unit & $\begin{array}{l}\text { Duplo } \\
\text { In }\end{array}$ & $\begin{array}{l}\text { Duplo } \\
\text { Out }\end{array}$ & $\begin{array}{l}\text { Duplo } \\
\text { In }\end{array}$ & $\begin{array}{l}\text { Duplo } \\
\text { Out }\end{array}$ & $\begin{array}{l}\% \\
\text { Change }\end{array}$ & $\begin{array}{l}\% \\
\text { Change }\end{array}$ \\
\hline $\mathrm{pH}$ & $1: 1$ & & 5.3 & 5.3 & 5.9 & 5.9 & 298 & 298 \\
\hline $\begin{array}{l}\text { Organic } \\
\text { Matter }\end{array}$ & W.B. & $\%$ & 14 & 12 & 17 & 12 & 25 & -4 \\
\hline Ammonium & $\mathrm{KCl}$ & $\mathrm{mg} / \mathrm{kg}$ & 13.8 & 24.7 & 6.5 & 6.0 & -53 & -76 \\
\hline Nitrate & $\mathrm{KCl}$ & $\mathrm{mg} / \mathrm{kg}$ & 15.3 & 32.8 & 1.4 & 2.0 & -91 & -94 \\
\hline Phosphorus & Bray & $\mathrm{mg} / \mathrm{kg}$ & 37 & 113 & 57 & 67 & 54 & -41 \\
\hline Zinc (total) & $\begin{array}{l}\text { NP-Dig 0- } \\
12\end{array}$ & $\mathrm{mg} / \mathrm{kg}$ & 197.24 & 166.61 & 193.84 & 161.09 & -2 & -3 \\
\hline Zinc & DTPA & $\mathrm{mg} / \mathrm{kg}$ & 45.4 & 40.6 & 34.3 & 30.2 & -24 & -26 \\
\hline $\begin{array}{l}\text { Copper } \\
\text { (total) }\end{array}$ & $\begin{array}{l}\text { NP-Dig 0- } \\
12\end{array}$ & $\mathrm{mg} / \mathrm{Kg}$ & 45.78 & 43.57 & 57.98 & 38.07 & 27 & -13 \\
\hline Copper & DTPA & $\mathrm{mg} / \mathrm{kg}$ & 7.9 & 6.6 & 9.6 & 4.8 & 22 & -27 \\
\hline Iron & DTPA & $\mathrm{mg} / \mathrm{kg}$ & 436 & 254 & 407 & 264 & -7 & 4 \\
\hline
\end{tabular}

Table 14: Soil sample results for Duplo IN and OUT sample locations, before and after treatment

\begin{tabular}{|c|c|c|c|c|c|c|c|c|}
\hline \multicolumn{3}{|c|}{$\begin{array}{l}\text { ROCKY - Control } \\
\text { Bioswale }\end{array}$} & $\begin{array}{l}27 \text { Sep } \\
\text { (S2) }\end{array}$ & $\begin{array}{l}27 \text { Sep } \\
\text { (S2) }\end{array}$ & $\begin{array}{l}24 \text { Feb } \\
\text { (S4) }\end{array}$ & $\begin{array}{l}24 \text { Feb } \\
\text { (S4) }\end{array}$ & $\begin{array}{l}\text { In } \\
\text { S2 to S4 }\end{array}$ & $\begin{array}{l}\text { Out } \\
\text { S2 to S4 }\end{array}$ \\
\hline Chemical & Test & Unit & $\begin{array}{l}\text { Rocky } \\
\text { In }\end{array}$ & $\begin{array}{l}\text { Rocky } \\
\text { Out }\end{array}$ & $\begin{array}{l}\text { Rocky } \\
\text { In }\end{array}$ & $\begin{array}{l}\text { Rocky } \\
\text { Out }\end{array}$ & $\begin{array}{l}\text { \% } \\
\text { Change }\end{array}$ & $\begin{array}{l}\% \\
\text { Change }\end{array}$ \\
\hline pH & $1: 1$ & & 5.7 & 5.5 & 5.9 & 5.8 & 58 & 100 \\
\hline $\begin{array}{l}\text { Organic } \\
\text { Matter }\end{array}$ & W.B. & $\%$ & 23.5 & 12.9 & 24.9 & 18.9 & 6 & 47 \\
\hline Ammonium & $\mathrm{KCl}$ & $\mathrm{mg} / \mathrm{kg}$ & 9.0 & 8.5 & 9.3 & 1.6 & 3 & -81 \\
\hline Nitrate & $\mathrm{KCl}$ & $\mathrm{mg} / \mathrm{kg}$ & 20.6 & 23.7 & 2.1 & 3.8 & -90 & -84 \\
\hline Phosphorus & Bray & $\mathrm{mg} / \mathrm{kg}$ & 41 & 88 & 45 & 73 & 10 & 17 \\
\hline Zinc (total) & $\begin{array}{l}\text { NP-Dig 0- } \\
12\end{array}$ & $\mathrm{mg} / \mathrm{kg}$ & 292.91 & 206.88 & 284.11 & 193.04 & -3 & -7 \\
\hline Zinc & DTPA & $\mathrm{mg} / \mathrm{kg}$ & 66.8 & 47.2 & 82.0 & 65.7 & 23 & 39 \\
\hline $\begin{array}{l}\text { Copper } \\
\text { (total) }\end{array}$ & $\begin{array}{l}\text { NP-Dig 0- } \\
12\end{array}$ & $\mathrm{mg} / \mathrm{Kg}$ & 69.77 & 52.33 & 74.38 & 41.60 & 7 & -21 \\
\hline Copper & DTPA & $\mathrm{mg} / \mathrm{kg}$ & 8.5 & 8.5 & 11.7 & 7.3 & 38 & -14 \\
\hline Iron & DTPA & $\mathrm{mg} / \mathrm{kg}$ & 226 & 252 & 353 & 416 & 56 & 65 \\
\hline
\end{tabular}

Table 15: Soil sample results for Rocky IN and OUT sample locations, before and after treatment 


\begin{tabular}{|c|c|c|c|c|c|c|}
\hline & & & $\begin{array}{l}\text { DUPLO IN } \\
\text { S2 to S4 }\end{array}$ & $\begin{array}{l}\text { ROCKY IN } \\
\text { S2 to S4 }\end{array}$ & $\begin{array}{l}\text { DUPLO OUT } \\
\text { S2 to S4 }\end{array}$ & $\begin{array}{l}\text { ROCKY OUT } \\
\text { S2 to S4 }\end{array}$ \\
\hline Metric & Test & Unit & \% Change & \% Change & \% Change & \% Change \\
\hline pH & $1: 1$ & & 298 & 58 & 298 & 100 \\
\hline Organic Matter & W.B. & $\%$ & 25 & 6 & -4 & 47 \\
\hline Ammonium & $\mathrm{KCl}$ & $\mathrm{mg} / \mathrm{kg}$ & -53 & 3 & -76 & -81 \\
\hline Nitrate & $\mathrm{KCl}$ & $\mathrm{mg} / \mathrm{kg}$ & -91 & -90 & -94 & -84 \\
\hline Phosphorus & Bray & $\mathrm{mg} / \mathrm{kg}$ & 54 & 10 & -41 & 17 \\
\hline Zinc (total) & NP-Dig 0-12 & $\mathrm{mg} / \mathrm{kg}$ & -2 & -3 & -3 & -7 \\
\hline Zinc & DTPA & $\mathrm{mg} / \mathrm{kg}$ & -24 & 23 & -26 & 39 \\
\hline Copper (total) & NP-Dig 0-12 & $\mathrm{mg} / \mathrm{Kg}$ & 27 & 7 & -13 & -21 \\
\hline Copper & DTPA & $\mathrm{mg} / \mathrm{kg}$ & 22 & 38 & -27 & -14 \\
\hline Iron & DTPA & $\mathrm{mg} / \mathrm{kg}$ & -7 & 56 & 4 & 65 \\
\hline
\end{tabular}

Table 16: Percent change for Duplo and Rocky In and Out between S2 and S4, 27

September 2015 to 24 February 2016 (Table 2)

\section{Stormwater Sample Results}

Stormwater 'In' samples were

collected from parking lot runoff flowing into

each bioswale. 'Out' samples were collected

from stormwater effluent after it passed

through the rock barrier delineating the

study. Since Moto had no drainage, 'Out'

samples were collected at the middle of the

pooling water (Figure 19). Stormwater

metrics include total phosphorus, chemical

oxygen demand (COD), zinc, copper, lead, and

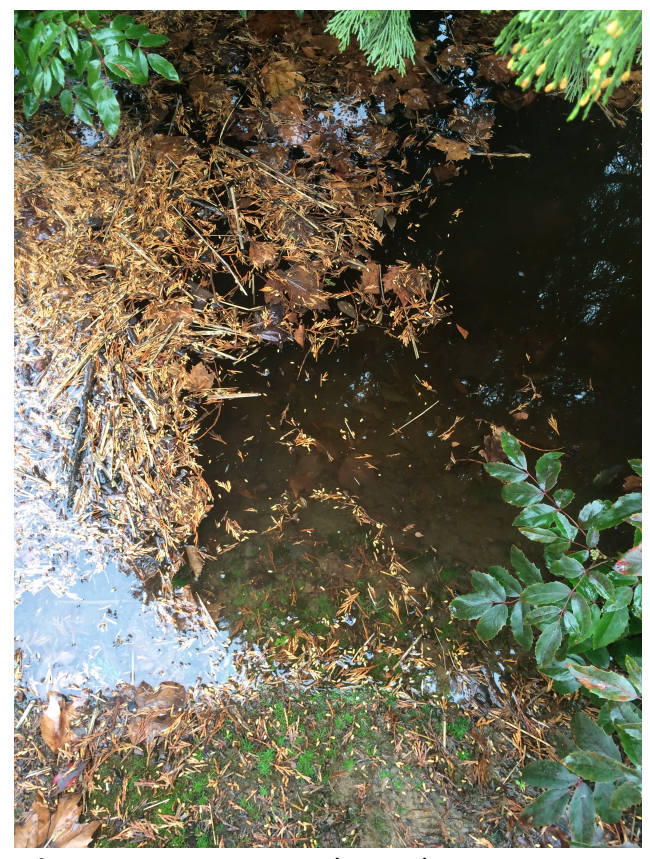

Figure 19: Moto sample pool

iron. Full results from stormwater sampling can be seen in Tables 17-19 and lab reports can be seen in Appendix C, followed by a summary of the metrics of interest with a focus on zinc, copper, and total phosphorus. 


\begin{tabular}{|l|l|l|r|l|l|l|}
\hline & Method & Unit & $\begin{array}{l}\text { Rocky } \\
\text { In }\end{array}$ & $\begin{array}{l}\text { Rocky } \\
\text { Out }\end{array}$ & $\begin{array}{l}\text { Duplo } \\
\text { In }\end{array}$ & $\begin{array}{l}\text { Duplo } \\
\text { Out }\end{array}$ \\
\hline Total Phosphorus & SM 4500-P-B5D & $\mathrm{mg} / \mathrm{L}$ & 0.06 & $\mathrm{ND}$ & $\mathrm{ND}$ & $\mathrm{ND}$ \\
COD & EPA 410.4 & $\mathrm{mg} / \mathrm{L}$ & $\mathrm{ND}$ & $\mathrm{ND}$ & $\mathrm{ND}$ & $\mathrm{ND}$ \\
Zinc & EPA200.7 & $\mathrm{mg} / \mathrm{L}$ & 0.01 & 0.03 & 0.02 & 0.01 \\
Copper & EPA200.7 & $\mathrm{mg} / \mathrm{L}$ & $\mathrm{ND}$ & $\mathrm{ND}$ & 0.00 & $\mathrm{ND}$ \\
Lead & EPA200.7 & $\mathrm{mg} / \mathrm{L}$ & $\mathrm{ND}$ & $\mathrm{ND}$ & $\mathrm{ND}$ & $\mathrm{ND}$ \\
Iron & EPA200.7 & $\mathrm{mg} / \mathrm{L}$ & 0.16 & 0.25 & 0.37 & 0.08 \\
\hline
\end{tabular}

Table 17: W1 Stormwater sample results for 12 December 2015

\begin{tabular}{|l|l|l|r|r|r|r|r|r|}
\hline Metric & Method & Unit & $\begin{array}{l}\text { Rocky } \\
\text { In }\end{array}$ & $\begin{array}{l}\text { Rocky } \\
\text { Out }\end{array}$ & $\begin{array}{l}\text { Duplo } \\
\text { In }\end{array}$ & $\begin{array}{l}\text { Duplo } \\
\text { Out }\end{array}$ & $\begin{array}{l}\text { Moto } \\
\text { In }\end{array}$ & $\begin{array}{l}\text { Moto } \\
\text { Pool }\end{array}$ \\
\hline Total & SM 4500-P- & & & & & & & \\
Phosphorus & B5D & $\mathrm{mg} / \mathrm{L}$ & 0.15 & 0.12 & 0.09 & 0.12 & 0.52 & 0.13 \\
COD & EPA 410.4 & $\mathrm{mg} / \mathrm{L}$ & 40.30 & 25.40 & 16.90 & ND & 340.00 & ND \\
Zinc & EPA200.7 & $\mathrm{mg} / \mathrm{L}$ & 0.29 & 0.03 & 0.03 & ND & 0.12 & 0.03 \\
Copper & EPA200.7 & $\mathrm{mg} / \mathrm{L}$ & 0.06 & ND & 0.01 & ND & 0.02 & ND \\
Lead & EPA200.7 & $\mathrm{mg} / \mathrm{L}$ & 0.03 & ND & ND & ND & 0.01 & ND \\
Iron & EPA200.7 & $\mathrm{mg} / \mathrm{L}$ & 9.98 & 0.67 & 1.33 & 0.16 & 3.93 & 0.25 \\
\hline
\end{tabular}

Table 18: W2 Stormwater sample results from 16 January 2016

\begin{tabular}{|l|l|l|r|r|r|r|r|r|}
\hline Metric & Method & Unit & $\begin{array}{l}\text { Rocky } \\
\text { In }\end{array}$ & $\begin{array}{l}\text { Rocky } \\
\text { Out }\end{array}$ & $\begin{array}{l}\text { Duplo } \\
\text { In }\end{array}$ & $\begin{array}{l}\text { Duplo } \\
\text { Out }\end{array}$ & $\begin{array}{l}\text { Moto } \\
\text { In }\end{array}$ & $\begin{array}{l}\text { Moto } \\
\text { Pool }\end{array}$ \\
\hline Total & SM 4500-P-B5D & $\mathrm{mg} / \mathrm{L}$ & 0.06 & 0.13 & 0.14 & $\mathrm{ND}$ & 0.09 & 0.23 \\
Phosphorus & EPA 410.4 & $\mathrm{mg} / \mathrm{L}$ & 11.70 & 18.70 & 41.80 & $\mathrm{ND}$ & 18.70 & 24.50 \\
COD & EPA200.7 & $\mathrm{mg} / \mathrm{L}$ & 0.02 & 0.03 & 0.03 & 0.01 & 0.01 & 0.06 \\
Zinc & EPA200.7 & $\mathrm{mg} / \mathrm{L}$ & $\mathrm{ND}$ & $\mathrm{ND}$ & 0.01 & $\mathrm{ND}$ & $\mathrm{ND}$ & 0.00 \\
Copper & EPA200.7 & $\mathrm{mg} / \mathrm{L}$ & $\mathrm{ND}$ & $\mathrm{ND}$ & $\mathrm{ND}$ & $\mathrm{ND}$ & $\mathrm{ND}$ & $\mathrm{ND}$ \\
Lead & EPA200.7 & $\mathrm{mg} / \mathrm{L}$ & 0.18 & 0.33 & 0.81 & 0.09 & 0.62 & 0.07 \\
Iron & SM9223BQty & & & & & & & \\
& 24HRColilert & $/ 100 \mathrm{ml}$ & 62.70 & 613.00 & 63.10 & 501.00 & 48.00 & 649.00 \\
E. coli & L & &
\end{tabular}

Table 19: W3 Stormwater sample results from 04 February 2016

\section{Stormwater Sample No.1 Results}

The first set of stormwater samples (W1) were collected 12 December 2015 between 09:57 and 10:18 following a storm event recorded by the nearby USGS rain gauge. The sample hour had $0.5 \mathrm{~cm}$ (0.18 in) of rain, the three hours prior to sampling had $0.8 \mathrm{~cm}(0.32 \mathrm{in})$, and the cumulative total for precipitation flowing through the media installation was $51.5 \mathrm{~cm}$ (20.27 in) (Table 2). 
For W1 Duplo In and Duplo Out were both a non-detect (ND) for total phosphorus (Table 17). Zinc levels for Duplo In were $0.02 \mathrm{mg} / \mathrm{L}$, and were reduced by $50 \%$ to $0.01 \mathrm{mg} / \mathrm{L}$ at Duplo Out. Copper for Duplo In was $0.00 \mathrm{mg} / \mathrm{L}$ and a nondetect for Duplo Out. Hence, values for three parameters where inputs were measured decreased after passing through the test media in the bioswale.

Total phosphorus for Rocky In was $0.06 \mathrm{mg} / \mathrm{L}$ and was reduced by $100 \%$ to a non-detect at Rocky Out. Zinc for stormwater collected at Rocky In was $0.01 \mathrm{mg} / \mathrm{L}$, and increased by $200 \%$, up to $0.03 \mathrm{mg} / \mathrm{L}$ at Rocky Out. Copper was a non-detect for both Rocky In and Rocky Out. With Rocky, treatment with just the stormwater filter media led to a decrease for phosphorus but allowed for an increase in zinc.

\section{Stormwater Sample No.2 Results}

The second set of stormwater samples (W2) were collected 16 January 2016 between 12:30 and 14:00. For this sample event there was $0.5 \mathrm{~cm}(0.20 \mathrm{in})$ in both the sample hour and the three hours prior, as it was the beginning of a rain event; cumulative precipitation from treatment installation was $77.9 \mathrm{~cm}$ (30.66 in) (Table 2). Samples were collected for Duplo In and Duplo Out (10m), Rocky In and Rocky Out (10m), and Moto In and the Moto Pool.

Total phosphorus for Duplo In was $0.09 \mathrm{mg} / \mathrm{L}$, which increased 33\% up to $0.12 \mathrm{mg} / \mathrm{L}$ at Duplo Out (Table 18). Zinc registered at $0.03 \mathrm{mg} / \mathrm{L}$ for stormwater collected at Duplo In, and was reduced 100\% down to a non-detect for Duplo Out. Copper was $0.01 \mathrm{mg} / \mathrm{L}$ at Duplo In, and also lowered 100\% to a non-detect at Duplo Out. 
Rocky In had a total phosphorus level of $0.15 \mathrm{mg} / \mathrm{L}$, and Rocky Out was reduced by $20 \%$ to $0.12 \mathrm{mg} / \mathrm{L}$. Zinc was $0.29 \mathrm{mg} / \mathrm{L}$ for Rocky In, and lowered $90 \%$ to $0.03 \mathrm{mg} / \mathrm{L}$ at Rocky Out. Copper was $0.06 \mathrm{mg} / \mathrm{L}$ for Rocky In, and dropped down $100 \%$ to a non-detect for Rocky Out. These results are similar to Duplo except that phosphorus increased 33\% in Duplo and lowered 20\% in Rocky.

Moto In had a total phosphorus level of $0.52 \mathrm{mg} / \mathrm{L}$, while Moto Pool stormwater tested $75 \%$ lower at $0.13 \mathrm{mg} / \mathrm{L}$. Zinc was $0.12 \mathrm{mg} / \mathrm{L}$ for Moto In, and was again reduced by $75 \%$, down to $0.03 \mathrm{mg} / \mathrm{L}$ in the Moto Pool. Copper measured at 0.02 for Moto In, and was lowered $100 \%$ to a non-detect in stormwater collected from the Moto Pool. Thus, values followed a similar trend as with Duplo and Rocky, except with phosphorus where there was a much larger reduction (-75\%).

\section{Stormwater Sample No.3 Results}

The third set of stormwater samples (W3) were collected 04 February 2016 between 10:30 and 11:30. The sample hour received $0.2 \mathrm{~cm}$ (0.08 in), the three hours prior received $0.9 \mathrm{~cm}$ ( $0.35 \mathrm{in})$, and the cumulative total for post-installation precipitation was $92.3 \mathrm{~cm}$ (36.34 in). In addition to the pre-defined metrics, there was an additional test included in W3 for Escherichia coli (E. coli) to see how the treatment might influence E. coli levels in stormwater effluent. Although E. coli is not a metric of focus in this study the results are reported for the benefit of stormwater managers looking at this metric (Table 19).

Duplo In registered at $0.14 \mathrm{mg} / \mathrm{L}$ total phosphorus, and Duplo Out reduced effluent levels $100 \%$ to a non-detect. Zinc measured at $0.03 \mathrm{mg} / \mathrm{L}$ for Duplo In, 
lowering $67 \%$ to $0.01 \mathrm{mg} / \mathrm{L}$ in stormwater collected at Duplo Out. Copper tested at $0.01 \mathrm{mg} / \mathrm{L}$ for Duplo In, reducing 100\% to a non-detect for Duplo Out.

Rocky In had a total phosphorus level of $0.06 \mathrm{mg} / \mathrm{L}$, which increased $117 \%$ to $0.12 \mathrm{mg} / \mathrm{L}$ at Rocky Out. Zinc was $0.02 \mathrm{mg} / \mathrm{L}$ for Rocky In, and increased by $50 \%$ to $0.03 \mathrm{mg} / \mathrm{L}$ for Rocky Out. Copper was a non-detect for both Rocky In and Rocky Out. These results reflect the differences between Rocky and Duplo in the effect the treatment has on the metrics of focus, especially zinc and phosphorus. In contrast to Duplo, both zinc and phosphorus levels in stormwater samples collected from Rocky increased (50\% and 117\%), while Duplo had reductions between $67 \%$ and $100 \%$ in all metrics detected.

Moto In had a total phosphorus level of $0.09 \mathrm{mg} / \mathrm{L}$, which increased $156 \%$ in the Moto Pool, being measured at $0.22 \mathrm{mg} / \mathrm{L}$. Zinc was $0.01 \mathrm{mg} / \mathrm{L}$ for Moto In, and again was much higher at $0.06 \mathrm{mg} / \mathrm{L}$ for Moto Pool, an increase of 500\%. Copper was a non-detect for both Moto In and the Moto Pool. Unlike the W2 samples, these results show a consistent increase in the metrics detected with this round of sampling similar to Rocky. Results for W1, W2, and W3 compared over time for Duplo, Rocky, and Moto can be seen in Tables 20, 21, and 22, respectively. The percent change for each metric in each bioswale for $\mathrm{W} 1, \mathrm{~W} 2$, and $\mathrm{W} 3$ is in Table 23. In summary, the results for W1 and W2 show reductions in the most of the metrics of interest in Duplo, Rocky, and Moto. This shifted for W3, approximately 17 weeks after treatment media installation, where Duplo continued to reduce contaminant levels while Rocky and Moto both demonstrated increases. 


\begin{tabular}{|c|c|c|c|c|c|c|c|c|}
\hline Metric & Method & Unit & $\begin{array}{l}\text { Duplo } \\
\text { In }\end{array}$ & $\begin{array}{l}\text { Duplo } \\
\text { Out }\end{array}$ & $\begin{array}{l}\text { Duplo } \\
\text { In }\end{array}$ & $\begin{array}{l}\text { Duplo } \\
\text { Out }\end{array}$ & $\begin{array}{l}\text { Duplo } \\
\text { In }\end{array}$ & $\begin{array}{l}\text { Duplo } \\
\text { Out }\end{array}$ \\
\hline $\begin{array}{l}\text { Total } \\
\text { Phosphorus }\end{array}$ & $\begin{array}{l}\text { SM 4500-P- } \\
\text { B5D }\end{array}$ & $\mathrm{mg} / \mathrm{L}$ & ND & ND & 0.09 & 0.12 & 0.14 & ND \\
\hline COD & EPA 410.4 & $\mathrm{mg} / \mathrm{L}$ & ND & ND & 16.90 & ND & 41.80 & ND \\
\hline Zinc & EPA200.7 & $\mathrm{mg} / \mathrm{L}$ & 0.02 & 0.01 & 0.03 & ND & 0.03 & 0.01 \\
\hline Copper & EPA200.7 & $\mathrm{mg} / \mathrm{L}$ & 0.00 & ND & 0.01 & ND & 0.01 & ND \\
\hline Lead & EPA200.7 & $\mathrm{mg} / \mathrm{L}$ & ND & ND & ND & ND & ND & ND \\
\hline Iron & EPA200.7 & $\mathrm{mg} / \mathrm{L}$ & 0.37 & 0.08 & 1.33 & 0.16 & 0.81 & 0.09 \\
\hline
\end{tabular}

Table 20: Stormwater results for Duplo compared for each sample event W1, W2, and W3

\begin{tabular}{|c|c|c|c|c|c|c|c|c|}
\hline ROCKY & & & $12 \mathrm{DEC}$ & $12 \mathrm{DEC}$ & $16 \mathrm{JAN}$ & $16 \mathrm{JAN}$ & 04 FEB & 04 FEB \\
\hline Metric & Method & Unit & $\begin{array}{l}\text { Rocky } \\
\text { In }\end{array}$ & $\begin{array}{l}\text { Rocky } \\
\text { Out }\end{array}$ & $\begin{array}{l}\text { Rocky } \\
\text { In }\end{array}$ & $\begin{array}{l}\text { Rocky } \\
\text { Out }\end{array}$ & $\begin{array}{l}\text { Rocky } \\
\text { In }\end{array}$ & $\begin{array}{l}\text { Rocky } \\
\text { Out }\end{array}$ \\
\hline $\begin{array}{l}\text { Total } \\
\text { Phosphorus }\end{array}$ & $\begin{array}{l}\text { SM 4500- } \\
\text { P-B5D }\end{array}$ & $\mathrm{mg} / \mathrm{L}$ & 0.06 & ND & 0.15 & 0.12 & 0.06 & 0.13 \\
\hline COD & EPA 410.4 & $\mathrm{mg} / \mathrm{L}$ & ND & ND & 40.30 & 25.40 & 11.70 & 18.70 \\
\hline Zinc & EPA200.7 & $\mathrm{mg} / \mathrm{L}$ & 0.01 & 0.03 & 0.29 & 0.03 & 0.02 & 0.03 \\
\hline Copper & EPA200.7 & $\mathrm{mg} / \mathrm{L}$ & ND & ND & 0.06 & ND & ND & ND \\
\hline Lead & EPA200.7 & $\mathrm{mg} / \mathrm{L}$ & ND & ND & 0.03 & ND & ND & ND \\
\hline Iron & EPA200.7 & $\mathrm{mg} / \mathrm{L}$ & 0.16 & 0.25 & 9.98 & 0.67 & 0.18 & 0.33 \\
\hline
\end{tabular}

Table 21: Stormwater results for Rocky compared for each sample event W1, W2, and W3

\begin{tabular}{|c|c|c|c|c|c|c|}
\hline Мото & & & 16 JAN & 16 JAN & 04 FEB & 04 FEB \\
\hline Metric & Method & Unit & $\begin{array}{l}\text { Moto } \\
\text { In }\end{array}$ & $\begin{array}{l}\text { Moto } \\
\text { Pool }\end{array}$ & $\begin{array}{l}\text { Moto } \\
\text { In }\end{array}$ & $\begin{array}{l}\text { Moto } \\
\text { Pool }\end{array}$ \\
\hline Total Phosphorus & SM 4500-P-B5D & $\mathrm{mg} / \mathrm{L}$ & 0.52 & 0.13 & 0.09 & 0.23 \\
\hline COD & EPA 410.4 & $\mathrm{mg} / \mathrm{L}$ & 340.00 & ND & 18.70 & 24.50 \\
\hline Zinc & EPA200.7 & $\mathrm{mg} / \mathrm{L}$ & 0.12 & 0.03 & 0.01 & 0.06 \\
\hline Copper & EPA200.7 & $\mathrm{mg} / \mathrm{L}$ & 0.02 & ND & ND & 0.00 \\
\hline Lead & EPA200.7 & $\mathrm{mg} / \mathrm{L}$ & 0.01 & ND & ND & ND \\
\hline Iron & EPA200.7 & $\mathrm{mg} / \mathrm{L}$ & 3.93 & 0.25 & 0.62 & 0.07 \\
\hline
\end{tabular}

Table 22: Stormwater results for Moto compared for sample events W1, W2, and W3

\begin{tabular}{|c|c|c|c|c|c|c|c|c|}
\hline & & & $12 \mathrm{DEC}$ & $12 \mathrm{DEC}$ & $16 \mathrm{JAN}$ & $16 \mathrm{JAN}$ & 04 FEB & 04 FEB \\
\hline Metric & Method & Unit & $\begin{array}{c}\text { ROCKY } \\
\% \\
\text { Change }\end{array}$ & $\begin{array}{c}\text { DUPLO } \\
\% \\
\text { Change }\end{array}$ & $\begin{array}{c}\text { ROCKY } \\
\% \\
\text { Change }\end{array}$ & $\begin{array}{c}\text { DUPLO } \\
\% \\
\text { Change }\end{array}$ & $\begin{array}{c}\text { ROCKY } \\
\% \\
\text { Change }\end{array}$ & $\begin{array}{c}\text { DUPLO } \\
\% \\
\text { Change }\end{array}$ \\
\hline $\begin{array}{l}\text { Total } \\
\text { Phosphorus }\end{array}$ & $\begin{array}{l}\text { SM 4500-P- } \\
\text { B5D }\end{array}$ & $\mathrm{mg} / \mathrm{L}$ & -100 & NA & -20 & 33 & 117 & -100 \\
\hline COD & EPA 410.4 & $\mathrm{mg} / \mathrm{L}$ & NA & NA & -37 & -100 & 60 & -100 \\
\hline Zinc & EPA200.7 & $\mathrm{mg} / \mathrm{L}$ & 200 & -50 & -90 & -100 & 50 & -67 \\
\hline Copper & EPA200.7 & $\mathrm{mg} / \mathrm{L}$ & NA & NA & -100 & -100 & NA & -100 \\
\hline Lead & EPA200.7 & $\mathrm{mg} / \mathrm{L}$ & NA & NA & -100 & NA & NA & NA \\
\hline Iron & EPA200.7 & $\mathrm{mg} / \mathrm{L}$ & 56 & -78 & -93 & -88 & 83 & -89 \\
\hline
\end{tabular}

Table 23: Percent change in stormwater metrics between IN and OUT for Rocky and Duplo.

Treatment was installed 11 October 2015 (Table 2) 


\section{Chapter 5: Discussion}

The objective of this study was to determine if mycoremediation and soil mycofiltration could improve urban water quality through strategic pairing with Earthlite $^{\mathrm{TM}}$ stormwater filter media in ecologically engineered structures. The enhancement of natural filtration is the goal of pairing mycoremediation and bioswales. This process was measured by comparing levels for each identified metric before and after $10 \mathrm{~m}$ of treatment. As discussed, one bioswale (Rocky), received a treatment of Earthlite ${ }^{\mathrm{TM}}$ stormwater filter blend with no amendments, and one bioswale (Duplo), received an application of stormwater filter media with PermaMatrix ${ }^{\circledR}$ BSP Foundation mycorrhizal fungi blend. It was anticipated that mycoremediation would improve stormwater quality by enhancing the function of the filter media blend, helping to reduce stormwater and soil levels of pollutants, particularly zinc, copper, and phosphorus, which were key metrics in this study.

Bioswales are a tool for reducing stormwater runoff and enhancing onsite infiltration. They are able to break down, remove, and immobilize many pollutants found in stormwater runoff by concentrating heavy metals through plant uptake or soil infiltration (Portland BES 2015; Oregon DEQ 2003). Soil organic matter levels, climate, $\mathrm{pH}$, and texture all influence pollutant mobility (Walker et al. 2012; Brady and Weil 1999). Soil retention of heavy metals and nutrients depend on pH (Oregon DEQ 2003) as most heavy metals are more mobile in an acidic environment (Walker et al 2012; Fomina et al. 2005; Brady and Weil 1999). 


\section{Soil Percent Change Before and After Treatment}

In order to assess the relative change in soil parameters as a function of the two treatments, the percent change was calculated for the difference between the pre-installation soil samples (S2) collected 27 September 2015, and soil samples collected 24 February 2016 (S4) concluding the study (Table 16).

Duplo, which had stormwater filter media that received the mycorrhizal treatment, had a 298\% increase in pH between S2 and S4 for both the In and Out sample locations (Table 16). Note that $\mathrm{pH}$ percent change calculations did account for the logarithmic scale of $\mathrm{pH}$. Organic matter at Duplo In increased 25\% after treatment and decreased at Duplo Out by 4\%. Ammonium was lowered in both the Duplo In and Out sample locations, decreasing $60 \%$ at Duplo In, and a greater reduction of $76 \%$ at Duplo Out. Nitrate had similar reductions at the In and Out soil sample locations, lowering $91 \%$ at Duplo In, and $94 \%$ at Duplo Out.

In Duplo, the metric of focus, phosphorus increased at Duplo In by $54 \%$, and decreased at Duplo Out by $41 \%$. Total zinc was lowered by $2 \%$ at Duplo In, while extractable zinc was reduced by $24 \%$; total zinc at Duplo Out reduced by $3 \%$ in comparison to extractable zinc which was lowered by $26 \%$ at the same site. Total copper increased 27\% at Duplo In, while extractable copper increased 22\%; in contrast to Duplo Out where total copper decreased 13\% and extractable copper reduced by $28 \%$.

The $\mathrm{pH}$ at Rocky In, the bioswale which received stormwater filter media with no mycorrhizal treatment, increased 58\% (Table 16). Rocky Out had a greater 
increase in $\mathrm{pH}$ at $100 \%$. Rocky In organic matter increased by 6\%, in contrast to Rocky Out which experienced an increase of $47 \%$. Ammonium was up 3\% at Rocky In, and down $81 \%$ at Rocky Out. Nitrate had more similar reductions for the In and Out sample sites, lowering 90\% for Rocky In, and reducing slightly less at $84 \%$ in Rocky Out. Phosphorus was up 10\% in Rocky In, and increased by 17\% in Rocky Out. Total zinc was reduced by $3 \%$ for Rocky In, and extractable zinc increased $23 \%$. In Rocky Out total zinc was down to 7\%, and in contrast to Duplo, extractable zinc levels increased 39\% at Rocky Out. Total copper in Rocky In increased by 7\%, while extractable copper experienced a concurrent increase of 38\%; total copper for Rocky Out reduced 21\%, and extractable copper lowered 14\%. Iron levels increased $56 \%$ in Rocky In, and 65\% in Rocky Out.

pH

The soil pH for Duplo In and Duplo Out both increased by 298\% after the study treatment period. There was no difference in soil pH between the Duplo In and Out sample sites. Rocky In had a 58\% increase and Rocky Out experienced a $100 \%$ increase. Soil and stormwater $\mathrm{pH}$ levels have a relationship that can help elucidate the results and the significance in differences between Duplo (Figures 20 and 21) and Rocky (Figures 22 and 23). These results indicate that both the stormwater filter media alone, and in combination with the fungi blend, have an alkalizing effect on soil. This result could be expected, given that biochar, a primary ingredient in the stormwater filter media, is known to be alkalizing (Gray 2015, unpublished research). However, the results of this study do show that the 
application of the mycorrhizal fungi PermaMatrix ${ }^{\circledR}$ BSP Foundation blend to the Earthlite $^{\text {tw }}$ stormwater filter media significantly increased soil alkalization.

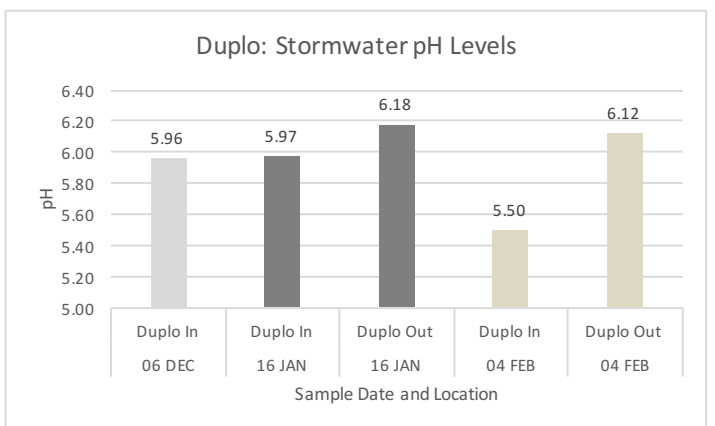

Figure 20: Duplo stormwater pH

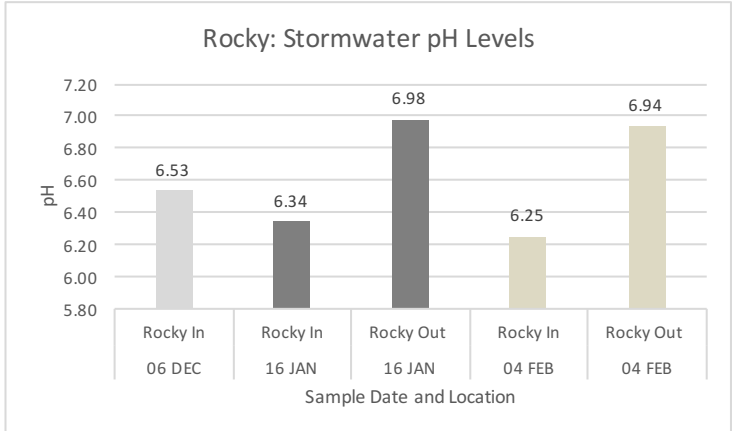

Figure 22: Rocky stormwater $\mathrm{pH}$

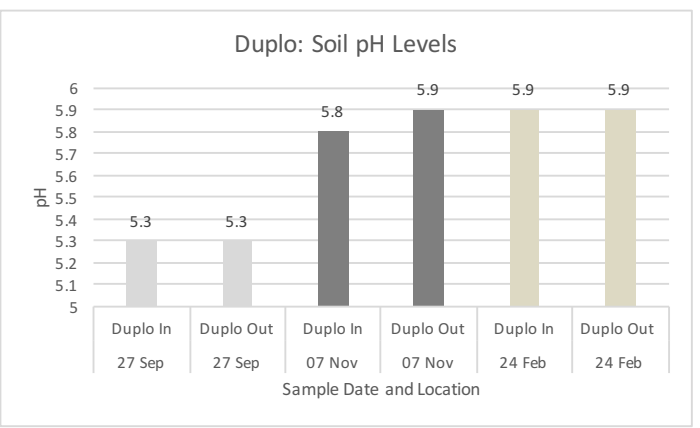

Figure 21: Duplo soil pH

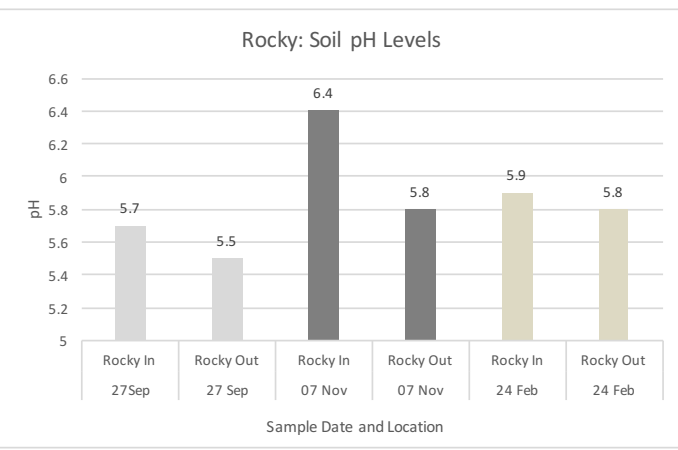

Figure 23: Rocky soil pH

The relationship between $\mathrm{pH}$ and mobility is important when considering potential for toxicity and bioremediation; $\mathrm{pH}$ is considered to be a "master variable" for soil (Schaetzl and Thompson 2015, 72). Heavy metals are less mobile in an alkaline environment (Walker et al. 2012; Brady and Weil 1999). The soil alkalization that was observed would have likely increased the stabilization of metals in the soil matrix while there was a simultaneous increase in mobility in the mycorrhizosphere as a result of the acids produced by both plants and fungi. 
If an element is bound to soil particles then it is less bioavailable, and there are less opportunities for toxic effects; however, the element will also be less available for uptake through bioremediation strategies (Meharg 2001). If a toxic element is mobile, then it will have more opportunities to interface with its surroundings and enter the food web where it will likely exert more toxic effects; yet, it will also be a better candidate for bioremediation strategies (Gadd 2001). Mycorrhizal fungi plays a role both directly and indirectly, affecting the $\mathrm{pH}$ itself through the secretion of acids, or by influencing the plant partner to alter its exudates and thus the rhizosphere/mycorrhizosphere chemistry (Leyval and Joner 2001).

\section{Organic Matter}

Organic matter at Duplo In increased 25\% after treatment, compared to Rocky In which experienced less of an increase at $6 \%$ (Table 16). Organic matter decreased at Duplo Out by 4\%, again in contrast to Rocky Out where organic matter increased by $47 \%$. Thus, Duplo In had more organic matter after the study period, while the opposite was true of Duplo Out and Rocky; organic matter was reduced in Duplo Out and increased in both Rocky In and Out. Given the relatively short time period for the study the differences in organic matter are not easily explained, however the results do seem to indicate a great deal of subsurface variation in organic matter.

Leaf litter accumulated in the pool where Rocky Out stormwater and soil samples were collected. Duplo Out was a longer bioswale with stormwater carrying 
litter another 10-15 meters before it would collect around the drain grate as it did in Rocky Out. Organic matter content was not a key metric and these confounding variables make it difficult to draw any conclusions about the influence of the treatment, but the data still provides useful information about the soil composition of the site.

\section{Ammonium}

Ammonium was reduced for Duplo In and Out soil samples after the treatment period, decreasing 53\% at Duplo In, and 76\% at Duplo Out. In contrast to the results for Duplo In, ammonium increased by 3\% at Rocky In. Rocky Out had results in the range of Duplo Out with an ammonium reduction of $81 \%$. The results indicate that treatment with mycorrhizal fungi appears to contribute to a larger and more consistent decrease in ammonium at this location.

There is greater mineral dissolution reported for mycorrhizal fungi with ammonium than with nitrate (Fomina et al. 2005). The main mechanism for solubilization of minerals when ammonium is the nitrogen source is acidification, thought to occur when hyphae excrete hydrogen $(\mathrm{H}+)$ during the uptake of ammonium (Fomina et al. 2005). Thus, at this site, the reductions in ammonium that occurred alongside reductions in metal levels support the conclusion that acidification may be one of the mechanisms playing a role in the mycorrhizosphere environment. However, these results must be considered within the context of an alkalizing soil environment, which confounds the results and limits potential for conclusions. 


\section{Nitrate}

After treatment, soil nitrate levels were lowered by $91 \%$ at Duplo In, and by 94\% at Duplo Out. In Rocky Out soil nitrate levels reduced by $90 \%$ for Rocky In, and $84 \%$ for Rocky Out. Although there is only a difference of $1 \%$ between the treatment Duplo In, and the control Rocky In, there is a difference in the percent change of nitrate levels between Duplo Out and Rocky Out after treatment. These results indicate that stormwater filter media by itself contributes to a reduction of soil nitrates; however, the mycorrhizal treatment enhances this reduction of soil nitrate when used in concert with the stormwater filter media.

Nutrient levels are of particular interest in urban bioremediation. Nutrient cycling is a fundamental ecological process that is relevant to resource managers and practitioners of bioremediation (Payn et al. 2005). Excess nutrients resulting from human activities causes eutrophication, a major concern for biological function in urban stream systems (Brady and Weil 1999). Mycorrhizal fungi play an important role in nutrient cycling, solubilizing nitrogen and phosphorus to feed mycelial growth and their plant hosts (Singh 2006; Fomina et al. 2005; Gadd 2001). In this manner they aid in reducing the levels of nitrogen being released into receiving waters and thus decreasing the possibility of eutrophication.

\section{Phosphorus}

Phosphorus inputs detected from stormwater were inconsistent in the first set of samples, W1. Duplo In and Duplo Out were both non-detects. Stormwater at Rocky In measured at $0.06 \mathrm{mg} / \mathrm{L}$ which was reduced by $100 \%$ down to a non-detect 
at Rocky Out. Phosphorus inputs increased for W2 and treatment results again varied; stormwater levels were $20 \%$ lower in effluent collected from Rocky Out when compared to Rocky In, and increased by 33\% in stormwater effluent that flowed through the treatment area Duplo. Stormwater flowed into the bioswales from multiple access points, so there could have been additional inputs causing this increase, or soil phosphorus could have been going into solution increasing stormwater phosphorus levels. The W2 sample results from Moto Pool showed a bioswale with no drainage and no treatment reducing stormwater phosphorus levels by $75 \%$.

The third stormwater sample was collected almost 17 weeks after installation of the mycorrhizal treatment and the Earthlite ${ }^{\text {tm }}$ stormwater filter media. Duplo In had more than double the phosphorus coming in, but after flowing through the treatment area levels were down $100 \%$ to a non-detect for Duplo Out, in contrast to Rocky which had less input yet increased levels of phosphorus by $117 \%$ in the stormwater effluent at Rocky Out. Moto also showed an increase with levels of phosphorus increasing 156\% between Moto In and the Moto Pool. Duplo stormwater and soil phosphorus levels can be seen in Figures 24 and 25, compared to Rocky in Figures 26 and 27.

These results indicate that the treatment is effective with respect to phosphorus, reducing total phosphorus in stormwater effluent after an establishment phase of 17 weeks. The stormwater samples provide evidence that there were phosphorus inputs over the course of the study period and that after an 
establishment period the bioswale with mycorrhizal treatment decreased phosphorus in stormwater and soil, in contrast to the bioswale with stormwater filter media alone, which caused increased levels of phosphorus. Relating stormwater levels to soil levels gives additional insight. Soil phosphorus increased at Duplo In by $54 \%$, and decreased at Duplo Out by $41 \%$ over the course of the study (S2 to S4). Phosphorus increased by $10 \%$ at Rocky In, and increased by $17 \%$ at Rocky Out. These results present further evidence that mycorrhizal treatment enhances the reduction of soil phosphorus.

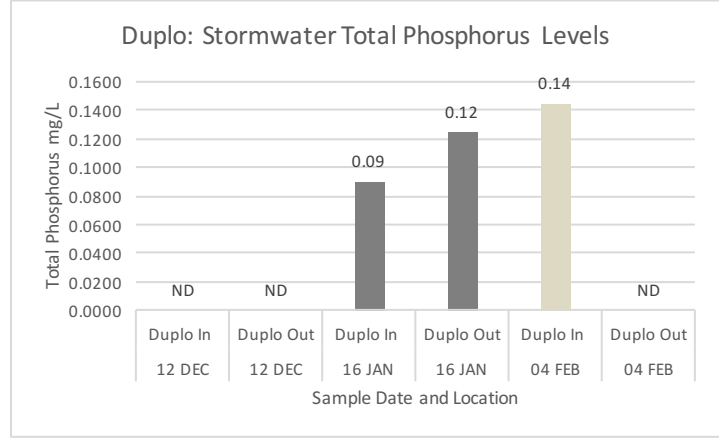

Figure 24: Duplo stormwater total phosphorus

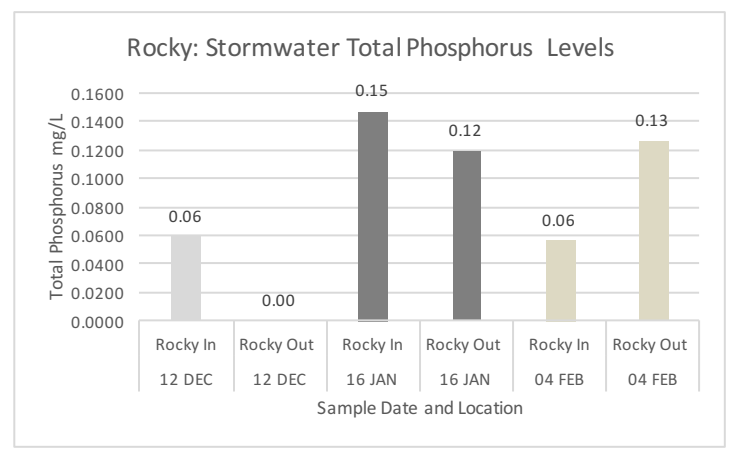

Figure 26: Rocky stormwater total phosphorus

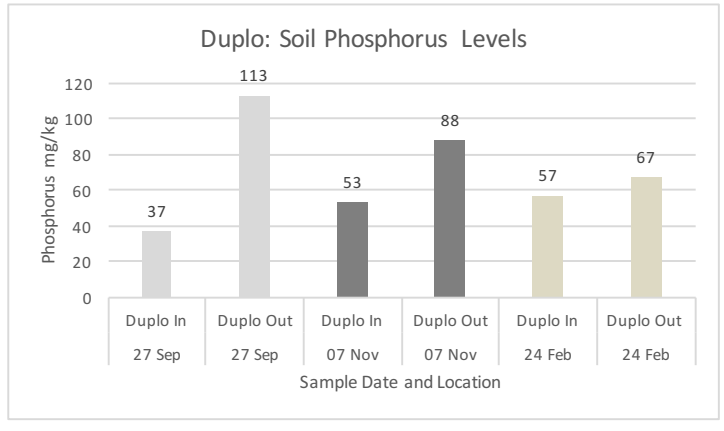

Figure 25: Duplo soil phosphorus

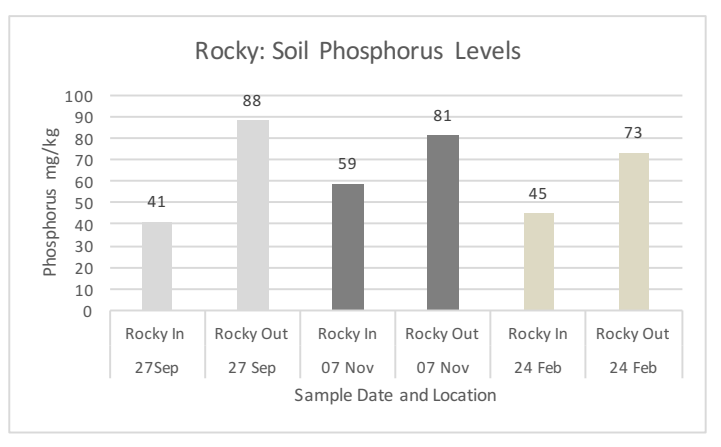

Figure 27: Rocky soil phosphorus

Mycorrhizal fungi have an important role in solubilizing phosphorus (Singh 2006; Fomina et al. 2005; Gadd 2001; Brady and Weil 1999). Phosphorus is 
important for plant growth but needs to be in the soluble phosphate form to be accessible for plants (Gadd 2001; Brady and Weil 1999). This relationship illustrates an important element of the mutual benefit plant and fungal partners experience from mycorrhizal symbiosis, where the mycelial web uses physical and chemical mechanisms to manipulate the rhizosphere/mycorrhizosphere environment, affecting decomposition, solubilization, and increasing access to nutrients and water (Schaetzl and Thompson 2015; Finlay 2008; Singh 2006; Khan 2000; Brady and Weil 1999).

When inorganic phosphates are solubilized, associated metals can be released (Fomina et al. 2005; Brady and Weil 1999). The solubilization of metals and mineral compounds can increase bioavailability and release anionic forms (Fomina et al. 2005). As discussed previously, increased dissolution results in increased mobility, which can increase toxicity for other organisms (Fomina et al. 2005; Gadd 2001). This does not appear to be the case for the treatment bioswale Duplo, who had concurrent reductions of levels of phosphorus, zinc, and copper in both soil and stormwater effluent.

\section{Zinc}

After the installation of the treatment media (S2), total zinc in Duplo In lowered 2\% and Duplo Out lowered 3\%. Although it is not a large percent change, levels do reduce even as zinc inputs continue. The slight reduction of total zinc is in contrast to changes in extractable zinc measurements before and after treatment between Duplo and Rocky. Extractable zinc in Duplo In reduced 24\% and Duplo Out 
lowered $26 \%$. Total zinc was reduced by $3 \%$ for Rocky In, while extractable zinc was up 23\%; similarly, Rocky Out had a reduction of 7\% for total zinc, but an increase in extractable zinc of 39\%. These results present evidence that the use of stormwater filter media alone can increase extractable zinc levels in bioswale soils while effecting small reductions in total zinc levels.

To summarize, after the treatment study period total zinc and extractable zinc levels at Duplo In and Out lowered 2\% and 24\%, and decreased 3\%, and 26\% respectively. In stark contrast to Duplo, total zinc and extractable zinc for Rocky In and Rocky Out reduced 3\%, increased 23\%, and again reduced 7\%, and increased up to $39 \%$ respectively.

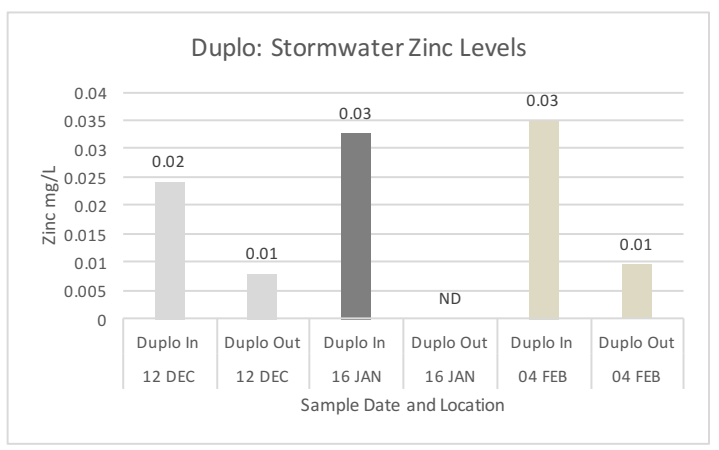

Figure 28: Duplo stormwater zinc

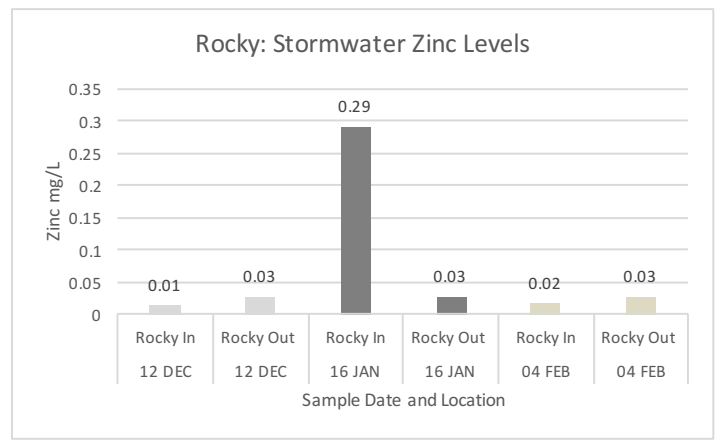

Figure 30: Rocky stormwater zinc

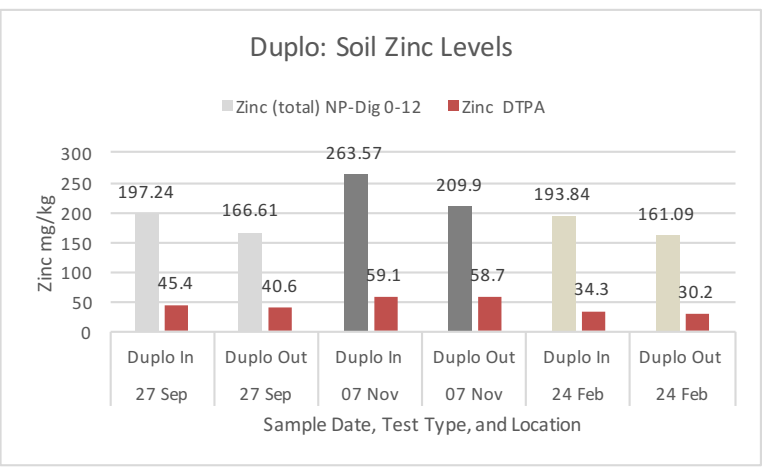

Figure 29: Duplo soil zinc

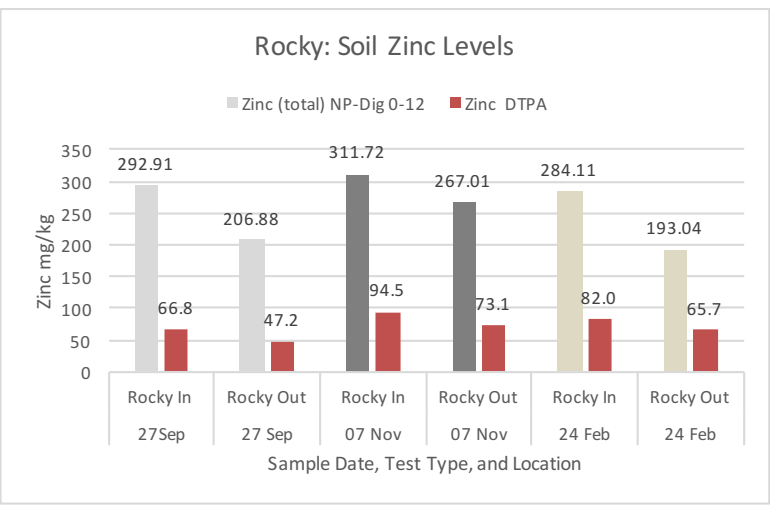

Figure 31: Rocky soil zinc 
As mentioned earlier, these changes in soil levels of zinc are experienced in the presence of ongoing inputs from stormwater runoff (Figures 28 - 31). The first stormwater samples (W1) were taken about 9 weeks after the installation. For W1 stormwater zinc levels for Duplo were reduced 50\% after flowing through the treatment area inoculated with mycorrhizal fungi through the application of the PermaMatrix ${ }^{\circledR}$ BSP Foundation blend. In contrast, stormwater zinc levels in Rocky increased $200 \%$ after flowing through the treatment area consisting of stormwater filter media alone.

The second set of stormwater samples (W2) were taken about 14 weeks after installation of the treatment. Zinc levels lowered $100 \%$ from $0.03 \mathrm{mg} / \mathrm{L}$ to a non-detect in stormwater flowing through Duplo. Zinc levels measured higher for stormwater runoff sampled going into Rocky than Duplo, and yet Rocky reduced stormwater zinc levels by 90\%. In addition, Moto Pool also showed reduced levels of zinc, with levels measured in Moto Pool lowered 75\% from levels detected in the runoff flowing in. These set of results confirm the input of zinc into the system and indicate that reductions in zinc in stormwater effluent will occur in bioswales with and without treatment, but that reductions in zinc are enhanced by the use of stormwater filter media.

The third set of stormwater samples (S3) were collected 04 February 2016, almost 17 weeks after the treatment was installed. Zinc levels were reduced in both soil and stormwater samples for Duplo and Rocky. Zinc levels were again lowered in stormwater effluent collected from Duplo, reduced by $67 \%$. Stormwater zinc input 
levels were lower for Rocky than Duplo but zinc levels in the effluent collected from Rocky still increased by 50\%. Zinc inputs into Moto were lower than the other bioswales, yet there was a large 500\% increase in zinc levels measured for Moto Pool. These results contribute to evidence of mycorrhiza enhancing the function of stormwater filter media over time. Additionally, these results demonstrate that mycorrhiza applied in situ, as was done in this study, would need time to establish the relationships with soil organisms that contribute to their ability to absorb, accumulate, and process pollutants and excess nutrients.

The stormwater sample results were not as significant by themselves, but in combination with the soil sample results, there was evidence that the application of PermaMatrix biotic soil amendment to Earthlite ${ }^{\text {'m }}$ stormwater filter media could contribute to the reduction of zinc in stormwater effluent (67\%) and a fair sized reduction of extractable zinc in bioswale soil (24\% and $26 \%$ ). This reduction in extractable zinc takes on additional significance when compared to the control, Rocky, who received a treatment of Earthlite ${ }^{\text {tm }}$ stormwater filter media only, and experienced an increase in extractable soil zinc levels of $23 \%$ and $39 \%$ for Rocky In and Rocky Out (respectively), along with increased levels of zinc in stormwater effluent (50\%).

\section{Copper}

Total copper at Duplo In increased 27\% between S2 and S4, and extractable copper increased 22\%. Total copper for Duplo Out reduced 13\%, while extractable copper reduced 27\% (Table 16). Total copper and extractable copper soil levels 
increased for Rocky In 7\%, and 38\%, respectively. For Rocky Out, total copper decreased $21 \%$, and extractable copper reduced $14 \%$.

Quantifying copper inputs from stormwater alongside soil levels adds additional context (Figures 32 - 34). Rocky was a non-detect for all samples except for W2 at Rocky In (not graphed). There were no measurable levels of copper coming into the system during the first stormwater sample event W1. For W2 samples, there were inputs of copper in the stormwater, and treatment by Duplo, Rocky, and Moto lowered levels down to non-detects. During the third stormwater sample (W3), overall inputs were lower. Copper was measured only at Duplo In, and was reduced to a non-detect at the outlet.

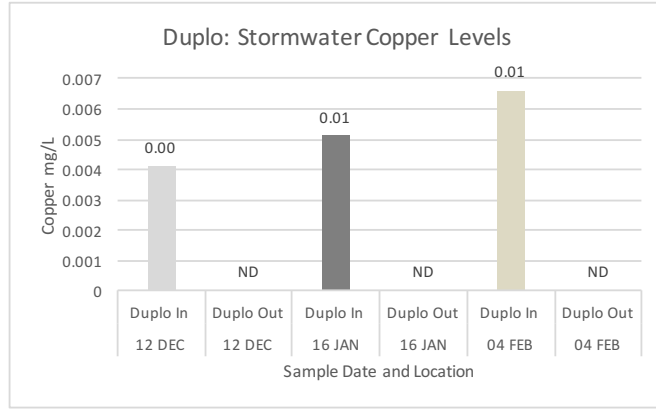

Figure 32: Duplo stormwater copper

The inconsistency in results for copper highlight the fact that three discrete samples collected over the course of one rainy season will not capture all inputs.

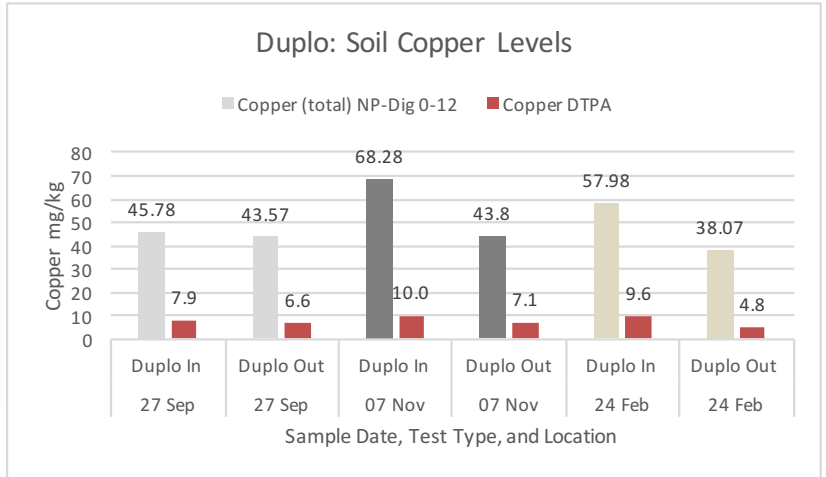

Figure 33: Duplo soil copper

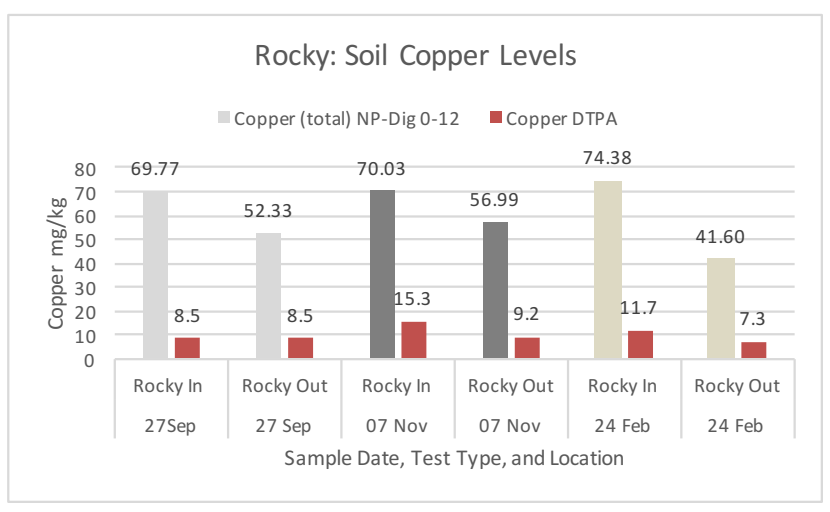

Figure 34: Rocky soil copper 
Collection of multiple samples from each precipitation event to create an event composite or mean, coupled with more sample events would have helped with quantification of inputs, however limited resources shifted efforts towards looking at results before and after treatment, along with percent change in stormwater flowing through the sample area.

In summary, results from stormwater sampling did not show large inputs but do indicate that treatment with both Earthlite ${ }^{\text {mw }}$ stormwater filter media and Earthlite $^{\text {tm }}$ stormwater filter media with an application of PermaMatrix ${ }^{\circledR}$ BSP Foundation biotic soil amendment may both be effective in lowering copper levels in stormwater.

With respect to bioswale soil, the results showed that treatment with both Earthlite $^{\text {tm }}$ stormwater filter media alone and with mycorrhizal treatment can reduce soil copper levels. There was a greater decrease in total copper in Rocky Out than Duplo, while Duplo had the greater decrease in extractable copper. After the course of treatment, total copper increased $27 \%$ at Duplo In, while extractable copper experienced a similar but slightly lower increase of $22 \%$. Total copper decreased 13\% at Duplo Out, while extractable copper reduced at a greater magnitude, lowering 27\%. Total copper measured at Rocky In increased 7\%, much less than Duplo, but extractable copper had a larger increase, jumping up 38\%. Total copper at Rocky Out lowered 21\%, and extractable copper lowered 14\%.

The results on copper were not consistent with results for zinc but they did indicate that the treatment is working to reduce stormwater and soil copper levels. 
The increases in soil copper levels indicate that there are stormwater inputs even though the sampling in this study showed minimal inputs, indicating temporal variation in stormwater pollutant loads. Both Duplo In and Rocky In experienced increases in soil levels of total copper and extractable copper, while both Duplo Out and Rocky Out had decreases in both total and extractable copper. The increases and decreases were not at similar levels; however, they did occur while some inputs from stormwater continued.

The varied reductions in zinc and copper levels could be the result of spatial variation in subsurface root and mycelial infrastructure in the mycorrhizosphere, where mycorrhiza, the root system, and the soil matrix all interface (Meharg 2001). Mycorrhizal fungi are able to tolerate and accumulate metals (Damodaran et al. 2013; Singh 2006), protecting plants by concentrating metals in the mycelial body, near the plant roots (Singh 2006). As mycorrhizal fungi solubilize and concentrate heavy metals soil levels of the metal minerals would likely be affected. Soil levels of metal minerals could be reduced as mycorrhizal solubilization concentrates the metals in the mycorrhizosphere around the hyphae, and in the tissues of both the fungi and its symbiotic plant partner. In this way, mycorrhizal treatment can enhance metal tolerance and phytoremediation capacity of plants used in ecological engineering structures and bioremediation, while effecting reductions in soil metal levels. This is an area that further inquiry could elucidate but results so far are promising. 
Ectomycorrhizal fungi protect plant hosts from metals by concentrating them in the walls of the extramatrical hyphae and slime, limiting mobility into plant roots (Tam 1995; Denny and Wilkins 1987(IV)). The mechanism for tolerance is reported to be the production of proteins similar to the protective metallothionein proteins found in humans and animals (Morselt et al. 1986). In addition, ectomycorrhizal fungi are known to develop a dense web around plant root systems, called a mantle, which forms a physical filter that pollutants must pass through before reaching the plant (Leyval and Joner 2001). It is believed that ectomycorrhizal fungi are well suited to long-term remediation because once the fungal organism has established itself with a tree host, the fungi can live for several years in a sustainable relationship with host organisms, while mycelia explore and colonize all surrounding soil that is accessible (Meharg and Cairney 2000).

There are still a great many unknowns when it comes to quantifying all of the mechanisms and pathways present in subsurface biotic soil communities where mycorrhizal fungi are active. Because of challenges in isolating variables it is useful to compare levels of metrics of interest before and after treatment even when identification of mechanisms and the fate of contaminants cannot be determined with certainty.

In this study PermaMatrix ${ }^{\circledR}$ BSP Foundation mycorrhizal biotic soil amendment enhanced the reduction of phosphorus in stormwater effluent and bioswale soil. The PermaMatrix ${ }^{\circledR}$ fungi treatment reduced levels of extractable zinc, and contributed to an increase in bioswale soil $\mathrm{pH}$. The application of fungi also 
appeared to contribute to a more consistent reduction in soil levels of ammonium, while enhancing the reduction of soil nitrates.

\section{Enhancing Plant Health and Phytoremediation Potential}

When considering mycoremediation as strategy for addressing urban watershed health, it is important to take into account the mycorrhizal and host plant status, physio-chemical conditions for growth, and how nutrient levels might affect mycorrhizal associations (Fomina et al. 2005). A healthy functioning biological community is the most important element for the function of a biofilter in the longterm (Oregon DEQ 2003). If plants are dormant then the suspended nutrients could remobilize, and the bioswale will cease to recycle nutrients efficiently (Oregon DEQ 2003). Mycorrhizal fungi can help protect plants from the negative effects of metal toxicity while supporting biological health, nutrient cycling, and overall plant resiliency (Gadd 2001; Khan et al. 2000).

The mechanisms that mycorrhizal fungi use to protect host plants from metal toxicity generally fall in two categories, avoidance or sequestration (Singh 2006), executed through solubilization or immobilization (Gadd 2001). The avoidance mechanisms are precipitation, biosorption, uptake, and efflux (Singh 2006). Gadd, citing their previous research, provides a good review of mechanisms in metal transformations (2001). Immobilization occurs through sorption, transport, sequestration, or precipitation (Gadd 2001; Leyval and Joner 2001). Sequestration uses the formation of compounds for intracellular chelation (Singh 2006). Solubilization occurs through complexation with compounds such as organic acids, 
metabolites, and siderophores (Gadd 2001). The process of heavy metals binding to extraradical mycelium is thought to have a role in heavy metal tolerance by ericaceous and ectomycorrhizal vegetation (Singh 2006). The relationship between plant and fungal partners affects the level of uptake of metals (Deiana et al. 2001; Gadd 2001; Hinsinger 2001; Leyval and Joner 2001) and the ability to immobilize metals has important implications for plant productivity and phytoremediation (Gadd 2001).

Establishment of mycorrhizal fungi in highly disturbed areas can have significant long-term effects on re-vegetation and plant productivity (Gadd 2001; Hetrick et al. 1993). Due to differences in the structure of the mycelial body of ectomycorrhizal fungi and arbuscular endomycorrhizal fungi it is important to plan for future potential land uses and to account for the long-term fate of any plants that might be used in remediation. Arbuscular mycorrhizal fungi have a less expansive fungal network and need host plants to grow (Meharg 2001), but this type of association dominates in the number of plants and geographic range (Finlay 2008; Singh 2006; Leyval and Joner 2001; Brady and Weil 1999) while helping protect plants from metal toxicity (Hildebrandt et al. 2007). Arbuscular mycorrhizal fungi are also known to decrease concentrations of zinc in host plants situated in highly contaminated soils (Heggo and Angle 1990; Hetrick et al 1994), which could be a useful property if metals need to be fully removed from soil at a contaminated site. 


\section{Unintended Zinc and Copper Inputs}

The third soil sample (S3), collected mid-study during the barrier swap helped to quantify inputs of zinc, copper, and iron that may have resulted from the use of metal flashing as opposed to just inputs from stormwater runoff.

The S3 soil sample results also provided mid-study soil samples for Duplo In at $0 \mathrm{~m}$, and Duplo Out at $10 \mathrm{~m}, 15 \mathrm{~m}$, and $20 \mathrm{~m}$. This range of soil samples helped to quantify increases in total and extractable levels of copper and zinc through the entire 20m Duplo study area. The increase in metal levels between S2 and S3 was not large, but important to address, as any unintended inputs could influence the study results. The increases in S3 along with subsequent decreases in S4 indicate an increased level of remediation alongside increasing inputs.

\section{Scalability of Mycoremediation}

To cultivate fungi, specific environmental conditions are often required, but in the natural environment fungi are ubiquitous (Singh 2006). Given that mushroom habitats include sand, burned areas, disturbed areas, pastures, wooded riparian areas, grasslands, lawns and gardens (Arora 1986) most areas could potentially be good candidates for mycoremediation. Furthermore, the fungal species being used in this study and in most mycoremediation projects are not known to be parasitic or invasive, at least as far as research associated with this study has shown.

There is research supporting the long-term use of mycoremediation and an increased capacity for fungal progeny to remediate contaminants that dominate its environment. Research by Fomina et al. (2005) concluded that there was a clear 
relationship between toxic metal tolerance, mineral solubilization, and metal uptake between populations from metal contaminated versus uncontaminated sites. Fungi sourced from contaminated sites are more tolerant and have demonstrated the ability to accumulate higher levels of the pollutants that dominated in the sites where the fungi was sourced (Fomina et al. 2005).

This relationship has implications for large-scale application of mycoremediation. Strains of fungi which are cultivated in a lab for general purpose use will not be adapted to site-specific pollutants. This does not mean that mycoremediation will not be effective with general purpose fungi blends as were used in this study; rather, it indicates that the in situ fungal progeny may be more efficient at pollutant remediation than the original organisms used.

\section{Maintenance of Mycoremediated Bioswales}

Once plant roots are saturated with toxic metals or compounds they may need to be removed and safely disposed of, which in some cases may mean hazardous waste disposal (NRCS Soil Quality 2000). This creates questions about which types of fungi would be suitable at different scales. Remediation plans need to account for full clean-up and offsite disposal of biological hyperaccumulators at a level that matches the scale of the site contamination. Use of ectomycorrhizal fungi in soil mycoremediation is recommended for sites where the metals can remain in situ and do not need to be removed (Meharg 2001). The fungal blend used in this study was dominated by ectomycorrhizal fungi. 


\section{5/2016 Water Year in Portland}

The stormwater samples collected offer a fair representation of precipitation events for the $2015 / 2016$ winter rain season; however it is important to discuss the effect that seasonality can have on bioswales. High rates of hydraulic loading can lead to anaerobic conditions over time that can result in a die-off of mycofiltration mycelia (Taylor and Stamets 2014). Precipitation events after dry, warm weather, especially in the fall, will also carry more pollutants (Göbel et al. 2006). The 2015/2016 winter rain season has had higher than normal levels of precipitation, breaking local records for annual rainfall. The CLIMB study site received $100.0 \mathrm{~cm}$ (39.37 in) of precipitation between the installation of the study media and collection of the final soil sample, which was above average for the water year, which starts 01 October and goes until 30 September (USGS Hydra Network 2016). The results of this study indicate that the treatment was effective in elevated precipitation conditions, and that die-off reported to be an issue in mycofiltration using fungal filters independent of in situ ecological systems (Stamets and Taylor 2014), in mycelium filled bags for example, was not an issue in mycoremediation of bioswale stormwater and soil in this study.

\section{Residence Time and Remediation}

The tracer dye study and the stormwater sample results confirmed that stormwater remains in each study bioswale for enough time to have meaningful contact with the treatment media. The results showed the variation in residence time between different precipitation events and between the two primary bioswales 
used in this study, Duplo and Rocky. The six minute and ninety second residence times reported for Duplo and Rocky respectively, are associated with a larger, less frequent precipitation event. Even so, there were consistent reductions in most stormwater metrics of interest for both Rocky and Duplo in W2 samples collected immediately before the tracer dye study was conducted; the only exception was a 33\% increase in phosphorus in Duplo. The similarity between the results in Rocky and Duplo for W1 and W2 indicate that differences in residence time were not critical, and that there was remediation occurring, likely resulting from a combination of phytoremediation and the presence of the stormwater filter media.

The Oregon Department of Environmental Quality reported on a study with a $75 \%$ minimum reduction of oil and grease in a bioswale that had a residence time of approximately 9 minutes (2003). The same bioswale reduced oil and grease 49\% after a shorter residence time of four and a half minutes (Oregon DEQ Soil Quality 2003). It is believed that increased residence time would likely improve the effectiveness of the treatment, however, even with short residence times and elevated precipitation levels the results show that treatment is effective.

\section{Future Research}

This research would benefit from additional long-term studies with multiple controls. In addition, automated stormwater sampling could capture first flush samples more effectively, allowing for researchers to account for variable contaminant levels over the course of a precipitation event, the season, and the year. There is a need for more in situ studies like this research, testing mycoremediation 
using real stormwater and polluted soils (Damodaran et al. 2013). There is also a need for lab research that accompanies in situ field studies. Lab studies could benefit from using soil that has developed and been contaminated in situ. Currently, most lab studies use soil columns that have been artificially polluted (Damodaran et al. 2013). Additional research on bioswales of varying ages could help quantify the ability for mycoremediated stormwater filter media to support plant health and biological function in a bioswale ecosystem while allowing for installations to function effectively for longer amounts of time, with less need for maintenance, soil amendments, and fertilizer inputs over time. 


\section{Chapter 6: Conclusion}

It is widely recognized that stormwater is a source of pollution and degradation for receiving waters (Göbel et al. 2006; Walsh et al. 2005). The increase in the percent of impervious surfaces leads to less infiltration in the watershed, reducing nutrient processing and uptake, washing street pollutants into stream systems and receiving waters (Walsh et al. 2005).

The benefit of treating urban stormwater on-site, and through soil infiltration is being increasingly recognized by public agencies (Portland BES 2015; Oregon DEQ 2003). In situ remediation is preferred because it is a lower cost method than removing the soil and it has less negative environmental impact than many other alternatives (Khan et al. 2000). There are many different strategies in bioremediation for managing heavy metal toxicity, and mycoremediation could be a powerful tool to add to the arsenal. The use of bioswales and other ecologically engineered structures to collect, infiltrate, and filter stormwater provides an effective and convenient container for the application of mycoremediation.

Mycoremediation could be an efficient, cost effective, and sustainable way to address water quality issues in the built environment. Fungi has been shown to absorb, and break down a broad range of pollutants, including bacteria, toxic chemicals, heavy metals, and petro-based compounds (Gusse and Volk 2014; Singh 2006; Stamets 2005). Arbuscular and ectomycorrhizal fungi can accumulate metals in their extramatrical hyphae and extrahyphal slime (Singh 2006; Tam 1995), 
solubilize metal minerals and nutrients, and help protect plants from heavy metal toxicity (Singh 2006; Gadd 2001; Leyval and Joner 2001).

The results presented here provide evidence that the application of PermaMatrix ${ }^{\circledR}$ BSP Foundation mycorrhizal treatment to Earthlite ${ }^{\text {tw }}$ stormwater filter media does indeed contribute to increased amelioration of the metrics of interest, as compared to the bioswale who received Earthlite ${ }^{\mathrm{Tm}}$ stormwater filter media alone. The bioswale that received an application of the PermaMatrix ${ }^{\circledR}$ treatment, reduced total zinc slightly and extractable zinc by $24 \%$ and $26 \%$, in contrast to the control bioswale who experienced comparatively large increases in extractable zinc (23\% and 39\%). Soil zinc reductions occurred while inputs from runoff continued, and zinc levels in stormwater effluent were reduced $67 \%$ for the treatment bioswale while the control experienced an increase of 50\%. Similarly, the bioswale with mycorrhizal treatment lowered extractable copper by $27 \%$, in contrast to another increase of $38 \%$ in the control. Results continued this trend with phosphorus, with treatment reducing levels of phosphorus in soil by $41 \%$ and stormwater effluent by $100 \%$ while levels in the control once again increased, by $17 \%$ in the soil and $117 \%$ in the stormwater effluent. Reductions in total phosphorus effluent increased with the study period time length. These results present evidence that the treatment increases the reduction of phosphorus, zinc, and copper in bioswale soil and stormwater effluent after an establishment phase of 17 weeks. 
Modern stormwater collection, filtration, and conveyance systems could benefit from the application of mycoremediation and mycofiltration strategies using mycorrhizal fungi. This study indicates that mycoremediation is an effective strategy, but long-term research with appropriate controls needs to be done in order to better quantify benefits and scalability. Potential applications for stormwater mycofiltration and mycoremediation include any vegetated infiltration based stormwater installations, such as bioswales, rain gardens, eco-roofs, bioretention cells, and flow-through planters. 


\section{References}

Arora, David. 1986. Mushrooms Demystified Second Edition. Ten Speed Press. Berkeley, United States.

Beiler, Kevin J., Daniel M. Durall, Suzanne W. Simard, Sheri A. Maxwell, and Annette M. Kretzer. 2010. Architecture of the Wood-Wide Web: Rhizopogon Spp. Genets Link Multiple Douglas-Fir Cohorts. New Phytologist 185 (2): 543-53.

Brady, Nyle C. and Ray R. Weil. 1999. The Nature and Property of Soils Twelfth Edition. Prentice-Hall. Upper Saddle River, New Jersey.

Cornelissen, J., R. Aerts, B. Cerabolini, M. Werger, and M. van der Heijden. 2001. Carbon Cycling Traits of Plant Species Are Linked with Mycorrhizal Strategy. Oecologia 129: 611-19.

Cotter, Tradd. 2014. Organic Mushroom Farming and Mycoremediation. Chelsea Green Publishing. White River Junction, United States.

Damodaran, Dilna, Raj Mohan Balakrishnan, and Vidya K Shetty. 2013. The Uptake Mechanism of Cd ( II ), Cr ( VI ), Cu ( II ), Pb ( II ), and Zn (II) by Mycelia and Fruiting Bodies of Galerina Vittiformis. BioMed Research International volume $2013 \# 149120$.

Davie, Tim. 2008. Fundamentals of Hydrology. Routledge. Oxon, England.

Davis, Allen P., Mohammad Shokouhian, and Shubei Ni. 2001. Loading Estimates of Lead, Copper, Cadmium, and Zinc in Urban Runoff from Specific Sources. Chemosphere 44 (5): 997-1009.

Denny, HJ, and DA Wilkins. 1987. Zinc Tolerance in Betula Spp (II) Microanalytical 
Studies of Zinc Uptake into Root Tissues. New Phytologist, 525-34.

Denny, Hilary J., and D. A. Wilkins. 1987. Zinc Tolerance in Betula Spp (IV) The Mechanism of Ectomycorrhizal Amelioration of Zinc Toxicity. New Phytologist 106: 545-53.

Deiana, Salvatore, Bruno Manunza, Amedeo Palma, Alessandra Premoli, and Carlo Gessa. 2001. Interactions and Mobilization of Metal Ions at the Soil-Root Interface. In Trace Elements in the Rhizosphere, eds. George R. Gobran, Walter W. Wenzel, and Enzo Lombi, 127-148. Papers sourced from the Fifth International Conference on Biogeochemistry of Trace Elements 11-15 July 1999 Vienna Austria. CRC Press. Florida, United States.

Feist, Blake E., Eric R. Buhle, Paul Arnold, Jay W. Davis, and Nathaniel L. Scholz. 2011. Landscape Ecotoxicology of Coho Salmon Spawner Mortality in Urban Streams. PLoS ONE 6 (8) e23424.

Finlay, Roger D. 2008. Ecological Aspects of Mycorrhizal Symbiosis: With Special Emphasis on the Functional Diversity of Interactions Involving the Extraradical Mycelium. Journal of Experimental Botany 59 (5): 1115-1126.

Fomina, M. A., I. J. Alexander, J. V. Colpaert, and G. M. Gadd. 2005. Solubilization of Toxic Metal Minerals and Metal Tolerance of Mycorrhizal Fungi. Soil Biology and Biochemistry 37 (5): 851-66.

Gadd, G.M., ed. 2001. Fungi in Bioremediation. British Mycological Society. Cambridge University Press. Cambridge, England. 
Gadd, Geoffrey M. 2001. Metal Transformations. In Fungi in Bioremediation, ed. G.M. Gadd, 445-455. British Mycological Society. Cambridge University Press. Cambridge, England.

Gavlak, Raymond George, Donald Arthur Horneck, and Robert O. Miller. 2003. Plant, soil, and water reference methods for the western region. Western Rural Development Center, Far West Fertilizer and Agrichemical Association. Corvallis, Oregon.

Glomus intraradices association with Medicago truncatula IMAGE [Figure 3]. 2016. Leibniz Institute of Plant Biochemistry. Sourced from <http://www.ipbhalle.de/en/public-relations/news/archives/projects/chemicalcommunication-in-the-rhizosphere/>.

Göbel, P., C. Dierkes, and W. G. Coldewey. 2007. Storm Water Runoff Concentration Matrix for Urban Areas. Journal of Contaminant Hydrology 91: 26-42.

Gusse, Adam C. and Thomas J. Volk. 2014. Mycorestoration. AccessScience, McGrawHill Education.

Gray, Myles. 16 September 2015. Biochar for Stormwater Treatment: Technology Overview and Research Update. Sustainable Stormwater Symposium. 16-17 September 2015 Alberta Abbey, Portland, Oregon.

Gray, Myles. 2015. Oregon State University Sunmark OregonBEST March 2015 Progress Report. Unpublished data. Accessed via personal communication March 2016.

Green Street Locations Map. 2015. Portland Bureau of Environmental Services. 
Sourced from https://www.portlandoregon.gov/bes/article/409925.

Green Street Care and Maintenance Guide (Steward's Guide). 2012. City of Portland Bureau of Environmental Services. Sourced from <https://www.portlandoregon.gov/bes/article/319879>.

Green Streets Frequently Asked Questions (WS 1383). 2013. Portland Bureau of Environmental Services. Sourced from <https://www.portlandoregon.gov/bes/article/212485>.

Green Street Locations (map). 2015. Portland Bureau of Environmental Services. Sourced from <https://www.portlandoregon.gov/bes/article/409925>. Green Street Overview. 2015. Portland Bureau of Environmental Services. Sourced from <https://www.portlandoregon.gov/bes/article/199748>. Hawksworth, David L. 2001. The Magnitude of Fungal Diversity: The 1.5 Million Species Estimate Revisited. Mycological Research 105 (December): 1422-32. Heggo, A. and J.S. Angle. 1990. Effects of vesicular-arbuscular mycorrhizal fungi on heavy metal uptake by soybeans. Soil Biology and Biochemistry 22(6): 865869.

Hetrick, B. A. D., G. W. T. Wilson, and D. A. H. Figge. 1994. The Influence of Mycorrhizal Symbiosis and Fertilizer Amendments on Establishment of Vegetation in Heavy Metal Mine Spoil. Environmental Pollution 86 (2): 17179.

Hildebrandt, Ulrich, Marjana Regvar, and Hermann Bothe. 2007. Arbuscular Mycorrhiza and Heavy Metal Tolerance. Phytochemistry 68 (1): 139-46. 
Hinsinger, Philippe. 2001. Bioavailability of Trace Elements as Related to RootInduced Chemical Changes in the Rhizospere. In Trace Elements in the Rhizosphere, eds. George R. Gobran, Walter W. Wenzel, and Enzo Lombi, 2541. Papers sourced from the Fifth International Conference on Biogeochemistry of Trace Elements 11-15 July 1999 Vienna Austria. CRC Press. Florida, United States.

HYDRA Rainfall Network (City of Portland). 2015. 5-Day Rainfall. Multnomah Rain Gage 501 S.E. Hawthorne Boulevard Station \#181. United States Geologic Survey. Sourced from <http://or.water.usgs.gov/precip/ multnomah.5day.html>. HYDRA Rainfall Network (City of Portland). 2016. 5-Day Rainfall. Multnomah Rain Gage 501 S.E. Hawthorne Boulevard Station \#181. United States Geologic Survey. Sourced from <http://or.water.usgs.gov/precip/multnomah.5day.html>.

Khan, A. G., C. Kuek, T. M. Chaudhry, C. S. Khoo, and W. J. Hayes. 2000. Role of Plants, Mycorrhizae and Phytochelators in Heavy Metal Contaminated Land Remediation. Chemosphere 41 (1-2): 197-207.

Krämer, Ute. 2005. Phytoremediation: Novel Approaches to Cleaning up Polluted Soils. Current Opinion in Biotechnology 16 (2): 133-41.

Krämer, U., R. D. Smith, W. W. Wenzel, I. Raskin, and D. E. Salt. 1997. The Role of Metal Transport and Tolerance in Nickel Hyperaccumulation by Thlaspi Goesingense Halacsy. Plant Physiology 115 (1997): 1641-50. 
Lafrenz, Martin. 2015. Modified Micro-Pipette Method for Particle Size Analysis. Personal communication. Portland State University Geography Department Soil Lab.

Leyval, Corinne and Erik J. Joner. 2001. Bioavailability of Heavy Metals in the Mycorrhizosphere. In Trace Elements in the Rhizosphere, eds. George R. Gobran, Walter W. Wenzel, and Enzo Lombi, 165-185. Papers sourced from the Fifth International Conference on Biogeochemistry of Trace Elements 1115 July 1999 Vienna Austria. CRC Press. Florida, United States.

Meharg, Andew A. 2001. The potential for using mycorrhizal associations in soil remediation. In Fungi in Bioremediation, eds. G.M. Gadd, 445-455. British Mycological Society. Cambridge University Press. Cambridge, England. Meharg, Andrew A., and John W. G. Cairney. 2000. Ectomycorrhizas - Extending the Capabilities of Rhizosphere Remediation? Soil Biology and Biochemistry 32 (11-12): 1475-84.

Morselt, A. F. W., W. T. M. Smits, and T. Limonard. 1986. Histochemical Demonstration of Heavy Metal Tolerance in Ectomycorrhizal Fungi. Plant and Soil 96: 417-20.

Molina, R., J.M. Trappe, L.C. Grubisha, and J.W. Spatafora. 1999. Rhizopogon. In Ectomycorrhizal fungi: key genera in profile, eds. W.G. Cairney and S.M. Chambers 129-160. Springer Verlag. Berlin, Germany. 
Mitsch, W. J. 1992. Landscape design and the role of created, restored, and natural riparian wetlands in controlling non-point source pollution. Ecological Engineering 1:27-47.

NRCS Soil Survey Field and Laboratory Methods Manual. 2014. Soil Survey Investigations Report No. 51 Version 2. United States Department of Agriculture Natural Resources Conservation Service. Sourced from <http:// www.nrcs.usda.gov/Internet/FSE_DOCUMENTS/stelprdb1244466.pdf>.

NRCS Soil Quality Institute. 2000. Soil Quality - Urban Technical Note No. 3 Heavy Metal Soil Contamination. United States Department of Agriculture Natural Resources Conservation Service. Sourced from <http://www.nrcs.usda.gov/ Internet/FSE_DOCUMENTS/nrcs142p2_053279.pdf?>.

Oregon Department of Environmental Quality (DEQ) 2003. Biofilters for Stormwater Discharge Pollution Removal. Water Quality Division. Sourced from $<$ http://www.deq.state.or.us/wq/stormwater/docs/biofiltersV2.pdf>.

Palmer, Margaret A., Solange Filoso, and Rosemary M. Fanelli. 2014. From Ecosystems to Ecosystem Services: Stream Restoration as Ecological Engineering. Ecological Engineering 65: 62-70.

Passeport, Elodie, Philippe Vidon, Kenneth J. Forshay, Lora Harris, Sujay S. Kaushal, Dorothy Q. Kellogg, Julia Lazar, Paul Mayer, and Emilie K. Stander. 2013. Ecological Engineering Practices for the Reduction of Excess Nitrogen in Human-Influenced Landscapes: A Guide for Watershed Managers. Environmental Management 51 (2): 392-413. 
Payn, Robert A., Jackson R. Webster, Patrick J. Mulholland, H. Maurice Valett, and Walter K. Dodds. 2005. Estimation of Stream Nutrient Uptake from Nutrient Addition Experiments. Limnology and Oceanography: Methods 3: 174-82.

Pisolithus tinctorius IMAGE [Figure 2]. 2016. Photograph by Dianna Smith. FungiKingdom.net. Sourced from <http://www.fungikingdom.net/fungiphotos/basidiomycota/ boletales-order/sclerodermatinaceaefamily/pisolithus-tinctorius6528.html>.

Read, D. J. 1991. Mycorrhizas in Ecosystems. Experientia 47 (4): 376-91.

Read, D. J., and J. Perez-Moreno. 2003. Mycorrhizas and Nutrient Cycling in Ecosystems - A Journey towards Relevance? New Phytologist 157 (3): 47592.

Rheaume, Andy; Douglas Howie; and Dylan Ahearn. 2015. Pollutant Export from Bioretention. StormH2O.com July/August.

Rhizopogon association with Medicago truncatula IMAGE [Figure 3]. 2013. Chemical communication in the rhizosphere. Leibniz Institute of Plant Biochemistry. Sourced from <http://www.ipb-halle.de/en/publicrelations/news/archives/projects/chemical-communication-in-therhizosphere/>.

Schaetzl, Randall J. and Michael L. Thompson. 2015. Soils: Genesis and Geomorphology Second Edition. Cambridge University Press. New York, United States.

Scholz, Nathaniel L., Mark S. Myers, Sarah G. McCarthy, Jana S. Labenia, Jenifer K. 
McIntyre, Gina M. Ylitalo, Linda D. Rhodes, et al. 2011. Recurrent Die-Offs of Adult Coho Salmon Returning to Spawn in Puget Sound Lowland Urban Streams. PLoS ONE 6 (12).

Shetty, K.G., B.A.D. Hetrick, and A.P. Schwab. 1995. Effect of Mycorrhizae and Fertilizer Amendments on Zinc Tolercance of Plants. Environmental Pollution 88: 307-14.

Singh, Harbhajan. 2006. Mycoremediation: Fungal Bioremediation. Wiley Interscience. New York, United States.

Smith and Read. 2008. Mycorrhizal Symbiosis Third Edition. Elsevier. Oxford, United Kingdom.

Spromberg, Julann A., David H. Baldwin, Steven E. Damm, Jenifer K. McIntyre, Michael Huff, Catherine A. Sloan, Bernadita F. Anulacion, Jay W. Davis, and Nathaniel L. Scholz. 2015. Coho Salmon Spawner Mortality in Western US Urban Watersheds: Bioinfiltration Prevents Lethal Storm Water Impacts. British Ecological Society. Journal of Applied Ecology 2015.

Stamets, Paul. 2005. Mycelium Running. Ten Speed Press. New York, United States. Stamets, Paul. 2006. Can Mushrooms Help Save the World? Explore: The Journal of Science and Healing 2(2): 152-161.

Stamets, Paul, Marc Beutel, Alex Taylor, and Alicia Flatt. 2013. Mycofiltration Biotechnology for Pathogen Management. Fungi Perfecti, LLC. Sourced from <http://fungi.com/pdf/articles/Fungi_Perfecti_Phase_I_Report.pdf $>$. Stormwater Solutions Handbook (WS 0603). 2015. Portland Bureau of 
Environmental Services. Sourced from

<https://www.portlandoregon.gov/bes/43110>.

Sustainable Site Development. 2003. Stormwater Practices for New, Redevelopment, and Infill Projects. Portland Bureau of Environmental Services. Sourced from $<$ https://www.portlandoregon.gov/bes/article/41619>.

Sustainable Stormwater Symposium. 16 and 17 September 2015. Oregon Chapter of the American Society of Civil Engineers Environment and Water Resources Group (ASCE-EWRG) and the Oregon Chapter of the American Public Works Association (APWA). Alberta Abbey. Portland, Oregon.

Tam, Paul C. F. 1995. Heavy Metal Tolerance by Ectomycorrhizal Fungi and Metal Amelioration by Pisolithus Tinctorius. Mycorrhiza 5: 181-87.

Taylor, Alex W., and Paul E. Stamets. 2014. Implementing Fungal Cultivation in Biofiltration Systems - The Past, Present, and Future of Mycofiltration The Dawn of Mycofiltration for Pathogen Management. USDA Forest Service Proceedings RMRSP-72: 23-28. Sourced from <http://www.fungi.com/ pdf/articles/Taylor_and_Stamets_Mycofiltration_USDA Proceedings_ 2014.pdf>.

Taylor, Alex, Alicia Flatt, Marc Beutel, Morgan Wolff, Katherine Brownson, and Paul Stamets. 2014. Removal of Escherichia Coli from Synthetic Stormwater Using Mycofiltration. Ecological Engineering 78: 79-86.

Tiefenthaler, Liesl L., Eric D. Stein, and Kenneth C. Schiff. 2008. Watershed and Land Use - Based Sources of Trace Metals in Urban Storm Water. Environmental 
Toxicology and Chemistry 27 (2): 277-87.

Types of Green Streets (WS 0895). 2008. City of Portland Bureau of Environmental

Services. Sourced from <http://www.oregon.gov/odf/BOARD/docs/

2014_Nov/BOFATTCH_20141105_03_04.pdf>.

Walker, C.H. R.M. Silby, S.P. Hopkin, and D.B. Peakall. 2012. Principles of

Ecotoxicology Fourth Edition. CRC Press. Boca Raton, United States.

Walsh, Christopher, Allison H. Roy, Jack W. Feminella, Peter D. Cottingham, Peter M.

Groffman, and Raymond P. Morgan II. 2005. The urban stream syndrome:

current knowledge and the search for a cure. Journal of the North American

Benthological Society 24(3): 706-723.

Water Environment Research Foundation. 2009. Portland, Oregon: Building a

Nationally Recognized Program Through Innovation and Research. Sourced from <http://www.werf.org/liveablecommunities/studies_port_or.htm>. 


\section{Appendices}

\section{Appendix A: Soil sample results}

A.1 S2 Soil Sample Results, collected 27 September 2015

\begin{tabular}{|c|c|c|c|c|c|c|c|c|}
\hline Chemical & Test & Unit & $\begin{array}{l}\text { Rocky } \\
\text { In } \\
\text { South }\end{array}$ & $\begin{array}{l}\text { Rocky } \\
\text { In } \\
\text { North }\end{array}$ & $\begin{array}{l}\text { Rocky } \\
\text { Out }\end{array}$ & $\begin{array}{l}\text { Duplo } \\
\text { North }\end{array}$ & $\begin{array}{l}\text { Duplo } \\
\text { South }\end{array}$ & $\begin{array}{l}\text { Duplo } \\
\text { Out }\end{array}$ \\
\hline $\mathrm{pH}$ & $1: 1$ & & 6.7 & 5.7 & 5.5 & 6.2 & 5.3 & 5.3 \\
\hline $\mathrm{pH}$ & $\mathrm{CaCl} 2$ & & 6.5 & 5.3 & 5 & 5.5 & 4.7 & 4.8 \\
\hline E.C. & $1: 1$ & $\mathrm{~m} . \mathrm{mhos} / \mathrm{cm}$ & 6.7 & 0.27 & 0.33 & 0.08 & 0.24 & 0.44 \\
\hline $\begin{array}{l}\text { Est Sat Paste } \\
\text { E.C. }\end{array}$ & & $\mathrm{m} . \mathrm{mhos} / \mathrm{cm}$ & 1.64 & 0.7 & 0.86 & 0.21 & 0.62 & 1.14 \\
\hline Buffer pH & SMP & & 6.5 & 5.9 & 5.7 & 6.2 & 5.4 & 5.7 \\
\hline $\begin{array}{l}\text { Cation } \\
\text { Exchange }\end{array}$ & CEC & meq/100g & 42.2 & 21 & 20.3 & 29.2 & 32.1 & 35.3 \\
\hline Total Bases & NH4OAC & meq/100g & 13.9 & 11.4 & 9 & 10.6 & 11.5 & 12.4 \\
\hline Base Saturation & $\mathrm{NH} 40 \mathrm{Ac}$ & $\%$ & 33 & 54.4 & 44.1 & 36.5 & 35.8 & 35.1 \\
\hline ESP & ESP & $\%$ & 0.4 & 0.6 & 0.6 & 0.4 & 0.6 & 0.3 \\
\hline Ammonium - N & $\mathrm{KCl}$ & $\mathrm{mg} / \mathrm{kg}$ & 4.6 & 9 & 8.5 & 19.1 & 13.8 & 24.7 \\
\hline Ammonium - N & $\mathrm{KCl}$ & Lbs/Acre & 15 & 29 & 27 & 61 & 44 & 79 \\
\hline Organic Matter & WB & $\%$ & 3.2 & 23.5 & 12.9 & 13.2 & 13.9 & 12.1 \\
\hline Nitrate - N & $\mathrm{KCl}$ & $\mathrm{mg} / \mathrm{kg}$ & 2.3 & 20.6 & 23.7 & 1.4 & 15.3 & 32.8 \\
\hline Nitrate - N & $\mathrm{KCl}$ & Lbs/Acre & 7 & 66 & 76 & 4 & 49 & 105 \\
\hline Sulfate-S & & $\mathrm{mg} / \mathrm{kg}$ & 12 & 13 & 15 & 8 & 16 & 14 \\
\hline Zinc & $\begin{array}{l}\text { NP-Dig } \\
0-12\end{array}$ & $\mathrm{mg} / \mathrm{kg}$ & 137.46 & 292.91 & 206.88 & 215.38 & 197.24 & 166.61 \\
\hline Zinc & DTPA & $\mathrm{mg} / \mathrm{kg}$ & 11.3 & 66.8 & 47.2 & 32.4 & 45.4 & 40.6 \\
\hline Copper & $\begin{array}{l}\text { NP-Dig } \\
0-12\end{array}$ & $\mathrm{mg} / \mathrm{Kg}$ & 36.12 & 69.77 & 52.33 & 63.96 & 45.78 & 43.57 \\
\hline Copper & DTPA & $\mathrm{mg} / \mathrm{kg}$ & 4.2 & 8.5 & 8.5 & 8.5 & 7.9 & 6.6 \\
\hline Phosphorus & Bray & $\mathrm{mg} / \mathrm{kg}$ & 95 & 41 & 88 & 65 & 37 & 113 \\
\hline Potassium & $\mathrm{NH} 40 \mathrm{AC}$ & $\mathrm{mg} / \mathrm{kg}$ & 206 & 133 & 129 & 88 & 185 & 294 \\
\hline Boron & DTPA & $\mathrm{mg} / \mathrm{kg}$ & 0.45 & 1.25 & 1.32 & 1.33 & 2.14 & 1.4 \\
\hline Manganese & DTPA & $\mathrm{mg} / \mathrm{kg}$ & 3.7 & 6.4 & 8.4 & 140.6 & 35.3 & 30.3 \\
\hline Iron & DTPA & $\mathrm{mg} / \mathrm{kg}$ & 82 & 226 & 252 & 266 & 436 & 254 \\
\hline Calcium & NH4OAC & meq/100g & 10.7 & 8.9 & 6.8 & 8.7 & 8.6 & 9.3 \\
\hline Magnesium & NH4OAC & $\mathrm{meq} / 100 \mathrm{~g}$ & 2.5 & 2 & 1.7 & 1.6 & 2.2 & 2.3 \\
\hline Sodium & NH4OAC & meq/100g & 0.18 & 0.12 & 0.13 & 0.13 & 0.2 & 0.09 \\
\hline
\end{tabular}


A.2 Duplo S3 Soil Sample Results, collected 07 November 2015

\begin{tabular}{|c|c|c|c|c|c|c|}
\hline Chemical & Test & Unit & Duplo In & $\begin{array}{l}\text { Duplo Out } \\
10 \mathrm{~m}\end{array}$ & $\begin{array}{l}\text { Duplo Out } \\
15 \mathrm{~m}\end{array}$ & $\begin{array}{l}\text { Duplo Out } \\
20 \mathrm{~m}\end{array}$ \\
\hline $\mathrm{pH}$ & $1: 1$ & & 5.8 & 5.9 & 5.3 & 5.5 \\
\hline pH & $\mathrm{CaCl} 2$ & & 5.4 & 5.2 & 4.8 & 5 \\
\hline E.C. 1:1 & $1: 1$ & $\mathrm{~m} . \mathrm{mhos} / \mathrm{cm}$ & 0.17 & 0.17 & 0.2 & 0.18 \\
\hline Est Sat Paste E.C. & & $\mathrm{m} \cdot \mathrm{mhos} / \mathrm{cm}$ & 0.44 & 0.44 & 0.52 & 0.47 \\
\hline Buffer pH & SMP & & 6.1 & 5.9 & 5.5 & 6 \\
\hline Cation Exchange & CEC & meq/100g & 21.8 & 23.2 & 25.5 & 22.9 \\
\hline Total Bases & NH4OAC & meq/100g & 13.7 & 14.8 & 12.5 & 15 \\
\hline Base Saturation & NH4OAC & $\%$ & 62.8 & 63.9 & 49 & 65.5 \\
\hline ESP & ESP & $\%$ & 0.9 & 0.4 & 0.5 & 0.5 \\
\hline Ammonium - N & $\mathrm{KCl}$ & $\mathrm{mg} / \mathrm{kg}$ & 7.4 & 5 & 5.7 & 11 \\
\hline Ammonium - $\mathbf{N}$ & $\mathrm{KCl}$ & Lbs/Acre & 24 & 16 & 18 & 35 \\
\hline Organic Matter & & & & & & \\
\hline W.B. & WB & $\%$ & 17.6 & 13.9 & 18.2 & 16.9 \\
\hline Nitrate - N & $\mathrm{KCl}$ & $\mathrm{mg} / \mathrm{kg}$ & 2.8 & 3.6 & 13.4 & 0.5 \\
\hline Nitrate - N & $\mathrm{KCl}$ & Lbs/Acre & 9 & 12 & 43 & 2 \\
\hline Sulfate-S & & $\mathrm{mg} / \mathrm{kg}$ & 0 & 0 & 0 & 0 \\
\hline Zinc & $\begin{array}{l}\text { NP-Dig 0- } \\
12\end{array}$ & $\mathrm{mg} / \mathrm{kg}$ & 263.57 & 209.9 & 199.22 & 194.81 \\
\hline Zinc & DTPA & $\mathrm{mg} / \mathrm{kg}$ & 59.1 & 58.7 & 55.6 & 60 \\
\hline Copper & $\begin{array}{l}\text { NP-Dig 0- } \\
12\end{array}$ & $\mathrm{mg} / \mathrm{Kg}$ & 68.28 & 43.8 & 42.71 & 46.07 \\
\hline Copper & DTPA & $\mathrm{mg} / \mathrm{kg}$ & 10 & 7.1 & 6.2 & 7.4 \\
\hline Phosphorus & Bray & $\mathrm{mg} / \mathrm{kg}$ & 53 & 88 & 56 & 97 \\
\hline Potassium & $\mathrm{NH} 4 \mathrm{OAC}$ & $\mathrm{mg} / \mathrm{kg}$ & 120 & 204 & 249 & 249 \\
\hline Boron & DTPA & $\mathrm{mg} / \mathrm{kg}$ & 1.43 & 1.22 & 1.65 & 1.43 \\
\hline Manganese & DTPA & $\mathrm{mg} / \mathrm{kg}$ & 42.2 & 18.7 & 17.2 & 125.4 \\
\hline Iron & DTPA & $\mathrm{mg} / \mathrm{kg}$ & 280 & 242 & 339 & 298 \\
\hline Calcium & NH4OAC & meq/100g & 11 & 11.6 & 9.4 & 11.8 \\
\hline Magnesium & NH4OAC & meq/100g & 2.2 & 2.6 & 2.3 & 2.5 \\
\hline Sodium & $\mathrm{NH} 4 \mathrm{OAC}$ & meq/100g & 0.19 & 0.1 & 0.13 & 0.12 \\
\hline
\end{tabular}


A.3 Rocky S3 Soil Sample Results, collected 07 November 2015

\begin{tabular}{|c|c|c|c|c|c|c|}
\hline Chemical & Test & Unit & $\begin{array}{l}\text { Rocky } \\
\text { In } \\
\text { South }\end{array}$ & $\begin{array}{l}\text { Rocky } \\
\text { Out } \\
\text { South }\end{array}$ & $\begin{array}{l}\text { Rocky } \\
\text { In } \\
\text { North } \\
\end{array}$ & $\begin{array}{l}\text { Rocky } \\
\text { Out } \\
\text { North }\end{array}$ \\
\hline $\mathrm{pH}$ & $1: 1$ & & 6.5 & 6 & 6.4 & 5.8 \\
\hline $\mathrm{pH}$ & $\mathrm{CaCl} 2$ & & 6.9 & 7.3 & 7.1 & 7.4 \\
\hline E.C. 1:1 & $1: 1$ & m.mhos/cm & 0.28 & 0.14 & 0.18 & 0.16 \\
\hline Est Sat Paste E.C. & & $\mathrm{m} . \mathrm{mhos} / \mathrm{cm}$ & 0.73 & 0.36 & 0.47 & 0.42 \\
\hline Buffer pH & SMP & & 7.3 & 7.3 & 7.3 & 7.4 \\
\hline Cation Exchange & CEC & meq/100g & 18.6 & 14.9 & 26.9 & 24 \\
\hline Total Bases & $\mathrm{NH} 4 \mathrm{OAC}$ & meq/100g & 15.4 & 12.4 & 20.8 & 14.1 \\
\hline Base Saturation & $\mathrm{NH} 4 \mathrm{OAC}$ & $\%$ & 82.8 & 83.1 & 77.6 & 58.8 \\
\hline ESP & ESP & $\%$ & 1.3 & 1 & 0.6 & 0.5 \\
\hline Ammonium - N & $\mathrm{KCl}$ & $\mathrm{mg} / \mathrm{kg}$ & 4.1 & 5.2 & 3.7 & 6.4 \\
\hline Ammonium - N & $\mathrm{KCl}$ & Lbs/Acre & 13 & 17 & 12 & 20 \\
\hline Organic Matter W.B. & WB & $\%$ & 10.5 & 9.5 & 2.5 & 17.9 \\
\hline Nitrate - N & $\mathrm{KCl}$ & $\mathrm{mg} / \mathrm{kg}$ & 1.4 & 1.4 & 3.3 & 2.5 \\
\hline Nitrate - N & $\mathrm{KCl}$ & Lbs/Acre & 4 & 4 & 11 & 8 \\
\hline Sulfate-S & & $\mathrm{mg} / \mathrm{kg}$ & 0 & 0 & 0 & 0 \\
\hline Zinc & NP-Dig 0-12 & $\mathrm{mg} / \mathrm{kg}$ & 163.84 & 229.28 & 311.72 & 267.01 \\
\hline Zinc & DTPA & $\mathrm{mg} / \mathrm{kg}$ & 27.8 & 56.3 & 94.5 & 73.1 \\
\hline Copper & NP-Dig 0-12 & $\mathrm{mg} / \mathrm{Kg}$ & 43.9 & 46.69 & 70.03 & 56.99 \\
\hline Copper & DTPA & $\mathrm{mg} / \mathrm{kg}$ & 5.6 & 8 & 15.3 & 9.2 \\
\hline Phosphorus & Bray & $\mathrm{mg} / \mathrm{kg}$ & 89 & 87 & 59 & 81 \\
\hline Potassium & $\mathrm{NH} 4 \mathrm{OAC}$ & $\mathrm{mg} / \mathrm{kg}$ & 320 & 178 & 255 & 203 \\
\hline Boron & DTPA & $\mathrm{mg} / \mathrm{kg}$ & 1.51 & 1.19 & 1.56 & 1.51 \\
\hline Manganese & DTPA & $\mathrm{mg} / \mathrm{kg}$ & 6.3 & 44 & 15.8 & 43.6 \\
\hline Iron & DTPA & $\mathrm{mg} / \mathrm{kg}$ & 137 & 242 & 288 & 306 \\
\hline Calcium & $\mathrm{NH} 4 \mathrm{OAC}$ & meq/100g & 10.9 & 9.4 & 16.7 & 10.8 \\
\hline Magnesium & $\mathrm{NH} 4 \mathrm{OAC}$ & meq/100g & 3.4 & 2.4 & 3.3 & 2.6 \\
\hline Sodium & $\mathrm{NH} 4 \mathrm{OAC}$ & meq/100g & 0.25 & 0.14 & 0.15 & 0.13 \\
\hline
\end{tabular}


A.4 Duplo S4 Soil Sample Results, collected 24 February 2016

\begin{tabular}{|c|c|c|c|c|c|}
\hline Metric & Test & Lab & Unit & Duplo In & Duplo Out \\
\hline $\mathrm{pH}$ & $1: 1$ & soiltest & & 5.9 & 5.9 \\
\hline pH & $\mathrm{CaCl} 2$ & soiltest & & 5.0 & 5.2 \\
\hline E.C. $1: 1$ & $1: 1$ & soiltest & $\mathrm{m} . \mathrm{mhos} / \mathrm{cm}$ & 0.05 & 0.05 \\
\hline Est Sat Paste E.C. & & soiltest & $\mathrm{m} \cdot \mathrm{mhos} / \mathrm{cm}$ & 0.13 & 0.13 \\
\hline Buffer pH & SMP & soiltest & & 6.2 & 6.2 \\
\hline Cation Exchange & CEC & soiltest & meq/100g & 20.7 & 21.4 \\
\hline Total Bases & NH4OAC & soiltest & meq/100g & 9.7 & 10.5 \\
\hline Base Saturation & NH4OAC & soiltest & $\%$ & 46.5 & 48.9 \\
\hline ESP & ESP & soiltest & $\%$ & 0.4 & 0.3 \\
\hline Ammonium - N & $\mathrm{KCl}$ & soiltest & $\mathrm{mg} / \mathrm{kg}$ & 6.5 & 6.0 \\
\hline Ammonium - N & $\mathrm{KCl}$ & soiltest & Lbs/Acre & 21 & 19 \\
\hline Organic Matter & WB & soiltest & $\%$ & 17.4 & 11.6 \\
\hline Nitrate - N & $\mathrm{KCl}$ & soiltest & $\mathrm{mg} / \mathrm{kg}$ & 1.4 & 2.0 \\
\hline Nitrate - N & $\mathrm{KCl}$ & soiltest & Lbs/Acre & 4 & 6 \\
\hline Sulfate-S & & soiltest & $\mathrm{mg} / \mathrm{kg}$ & 15 & 10 \\
\hline Zinc & NP-Dig 0-12 & soiltest & $\mathrm{mg} / \mathrm{kg}$ & 193.84 & 161.09 \\
\hline Zinc & DTPA & soiltest & $\mathrm{mg} / \mathrm{kg}$ & 34.3 & 30.2 \\
\hline Copper & NP-Dig 0-12 & soiltest & $\mathrm{mg} / \mathrm{Kg}$ & 57.98 & 38.07 \\
\hline Copper & DTPA & soiltest & $\mathrm{mg} / \mathrm{kg}$ & 9.6 & 4.8 \\
\hline Phosphorus & Bray & soiltest & $\mathrm{mg} / \mathrm{kg}$ & 57 & 67 \\
\hline Potassium & NH4OAC & soiltest & $\mathrm{mg} / \mathrm{kg}$ & 48 & 127 \\
\hline Boron & DTPA & soiltest & $\mathrm{mg} / \mathrm{kg}$ & 1.76 & 1.17 \\
\hline Manganese & DTPA & soiltest & $\mathrm{mg} / \mathrm{kg}$ & 49.8 & 23.3 \\
\hline Iron & DTPA & soiltest & $\mathrm{mg} / \mathrm{kg}$ & 407 & 264 \\
\hline Calcium & NH4OAC & soiltest & meq/100g & 7.9 & 8.2 \\
\hline Magnesium & $\mathrm{NH} 4 \mathrm{OAC}$ & soiltest & meq/100g & 1.6 & 1.9 \\
\hline Sodium & NH4OAC & soiltest & meq/100g & 0.07 & 0.07 \\
\hline
\end{tabular}


A.5 Rocky S4 Soil Sample Results, collected 24 February 2016

\begin{tabular}{|c|c|c|c|c|c|}
\hline Metric & Test & Lab & Unit & Rocky In & Rocky Out \\
\hline $\mathrm{pH}$ & $1: 1$ & soiltest & & 5.9 & 5.8 \\
\hline pH & $\mathrm{CaCl} 2$ & soiltest & & 5.2 & 5.1 \\
\hline E.C. $1: 1$ & $1: 1$ & soiltest & $\mathrm{m} . \mathrm{mhos} / \mathrm{cm}$ & 0.15 & 0.15 \\
\hline Est Sat Paste E.C. & & soiltest & $\mathrm{m} . \mathrm{mhos} / \mathrm{cm}$ & 0.39 & 0.39 \\
\hline Buffer pH & SMP & soiltest & & 5.8 & 6.1 \\
\hline Cation Exchange & CEC & soiltest & $\mathrm{meq} / 100 \mathrm{~g}$ & 24.9 & 21.6 \\
\hline Total Bases & NH4OAC & soiltest & meq/100g & 14.5 & 11.5 \\
\hline Base Saturation & NH4OAC & soiltest & $\%$ & 58.2 & 53.2 \\
\hline ESP & ESP & soiltest & $\%$ & 0.4 & 0.3 \\
\hline Ammonium - $\mathbf{N}$ & $\mathrm{KCl}$ & soiltest & $\mathrm{mg} / \mathrm{kg}$ & 9.3 & 1.6 \\
\hline Ammonium - $\mathbf{N}$ & $\mathrm{KCl}$ & soiltest & Lbs/Acre & 30 & 5 \\
\hline Organic Matter & WB & soiltest & $\%$ & 24.9 & 18.9 \\
\hline Nitrate - N & $\mathrm{KCl}$ & soiltest & $\mathrm{mg} / \mathrm{kg}$ & 2.1 & 3.8 \\
\hline Nitrate - N & $\mathrm{KCl}$ & soiltest & Lbs/Acre & 7 & 12 \\
\hline Sulfate-S & & soiltest & $\mathrm{mg} / \mathrm{kg}$ & 17 & 15 \\
\hline Zinc & NP-Dig 0-12 & soiltest & $\mathrm{mg} / \mathrm{kg}$ & 284.11 & 193.04 \\
\hline Zinc & DTPA & soiltest & $\mathrm{mg} / \mathrm{kg}$ & 82.0 & 65.7 \\
\hline Copper & NP-Dig 0-12 & soiltest & $\mathrm{mg} / \mathrm{Kg}$ & 74.38 & 41.60 \\
\hline Copper & DTPA & soiltest & $\mathrm{mg} / \mathrm{kg}$ & 11.7 & 7.3 \\
\hline Phosphorus & Bray & soiltest & $\mathrm{mg} / \mathrm{kg}$ & 45 & 73 \\
\hline Potassium & $\mathrm{NH} 4 \mathrm{OAC}$ & soiltest & $\mathrm{mg} / \mathrm{kg}$ & 132 & 106 \\
\hline Boron & DTPA & soiltest & $\mathrm{mg} / \mathrm{kg}$ & 1.56 & 1.87 \\
\hline Manganese & DTPA & soiltest & $\mathrm{mg} / \mathrm{kg}$ & 65.2 & 65.3 \\
\hline Iron & DTPA & soiltest & $\mathrm{mg} / \mathrm{kg}$ & 353 & 416 \\
\hline Calcium & $\mathrm{NH} 4 \mathrm{OAC}$ & soiltest & meq/100g & 11.6 & 9.1 \\
\hline Magnesium & NH4OAC & soiltest & meq/100g & 2.4 & 2.0 \\
\hline Sodium & NH4OAC & soiltest & $\mathrm{meq} / 100 \mathrm{~g}$ & 0.11 & 0.07 \\
\hline
\end{tabular}


A.6 Moto S4 Soil Sample Results, collected 24 February 2016

\begin{tabular}{|c|c|c|c|c|c|}
\hline Metric & Test & Lab & Unit & Moto In & Moto Pool \\
\hline pH & $1: 1$ & soiltest & & 6.2 & 6.4 \\
\hline $\mathrm{pH}$ & $\mathrm{CaCl} 2$ & soiltest & & 5.5 & 5.6 \\
\hline E.C. $1: 1$ & $1: 1$ & soiltest & $\mathrm{m} . \mathrm{mhos} / \mathrm{cm}$ & 0.10 & 0.07 \\
\hline Est Sat Paste E.C. & & soiltest & m.mhos/cm & 0.26 & 0.18 \\
\hline Buffer pH & SMP & soiltest & & 6.4 & 6.4 \\
\hline Cation Exchange & CEC & soiltest & meq/100g & 18.6 & 22.3 \\
\hline Total Bases & NH4OAC & soiltest & meq/100g & 13.5 & 14.4 \\
\hline Base Saturation & NH4OAC & soiltest & $\%$ & 72.5 & 64.5 \\
\hline ESP & ESP & soiltest & $\%$ & 0.3 & 0.3 \\
\hline Ammonium - $\mathbf{N}$ & $\mathrm{KCl}$ & soiltest & $\mathrm{mg} / \mathrm{kg}$ & 5.9 & 9.3 \\
\hline Ammonium - N & $\mathrm{KCl}$ & soiltest & Lbs/Acre & 19 & 30 \\
\hline Organic Matter & WB & soiltest & $\%$ & 11.3 & 13.1 \\
\hline Nitrate - N & $\mathrm{KCl}$ & soiltest & $\mathrm{mg} / \mathrm{kg}$ & 1.0 & 1.5 \\
\hline Nitrate - N & $\mathrm{KCl}$ & soiltest & Lbs/Acre & 3 & 5 \\
\hline Sulfate-S & & soiltest & $\mathrm{mg} / \mathrm{kg}$ & 9 & 8 \\
\hline Zinc & NP-Dig 0-12 & soiltest & $\mathrm{mg} / \mathrm{kg}$ & 241.45 & 331.05 \\
\hline Zinc & DTPA & soiltest & $\mathrm{mg} / \mathrm{kg}$ & 43.0 & 71.4 \\
\hline Copper & NP-Dig 0-12 & soiltest & $\mathrm{mg} / \mathrm{Kg}$ & 56.88 & 53.93 \\
\hline Copper & DTPA & soiltest & $\mathrm{mg} / \mathrm{kg}$ & 8.4 & 6.6 \\
\hline Phosphorus & Bray & soiltest & $\mathrm{mg} / \mathrm{kg}$ & 85 & 90 \\
\hline Potassium & NH4OAC & soiltest & $\mathrm{mg} / \mathrm{kg}$ & 210 & 181 \\
\hline Boron & DTPA & soiltest & $\mathrm{mg} / \mathrm{kg}$ & 0.58 & 0.71 \\
\hline Manganese & DTPA & soiltest & $\mathrm{mg} / \mathrm{kg}$ & 44.0 & 19.9 \\
\hline Iron & DTPA & soiltest & $\mathrm{mg} / \mathrm{kg}$ & 132 & 163 \\
\hline Calcium & NH4OAC & soiltest & meq/100g & 11.0 & 10.6 \\
\hline Magnesium & $\mathrm{NH} 4 \mathrm{OAC}$ & soiltest & $\mathrm{meq} / 100 \mathrm{~g}$ & 1.9 & 3.3 \\
\hline Sodium & NH4OAC & soiltest & meq/100g & 0.06 & 0.06 \\
\hline
\end{tabular}




\section{Appendix B: Soil sample lab reports}

B.1 S2 Lab report for Rocky In South, collected 27 September 2015

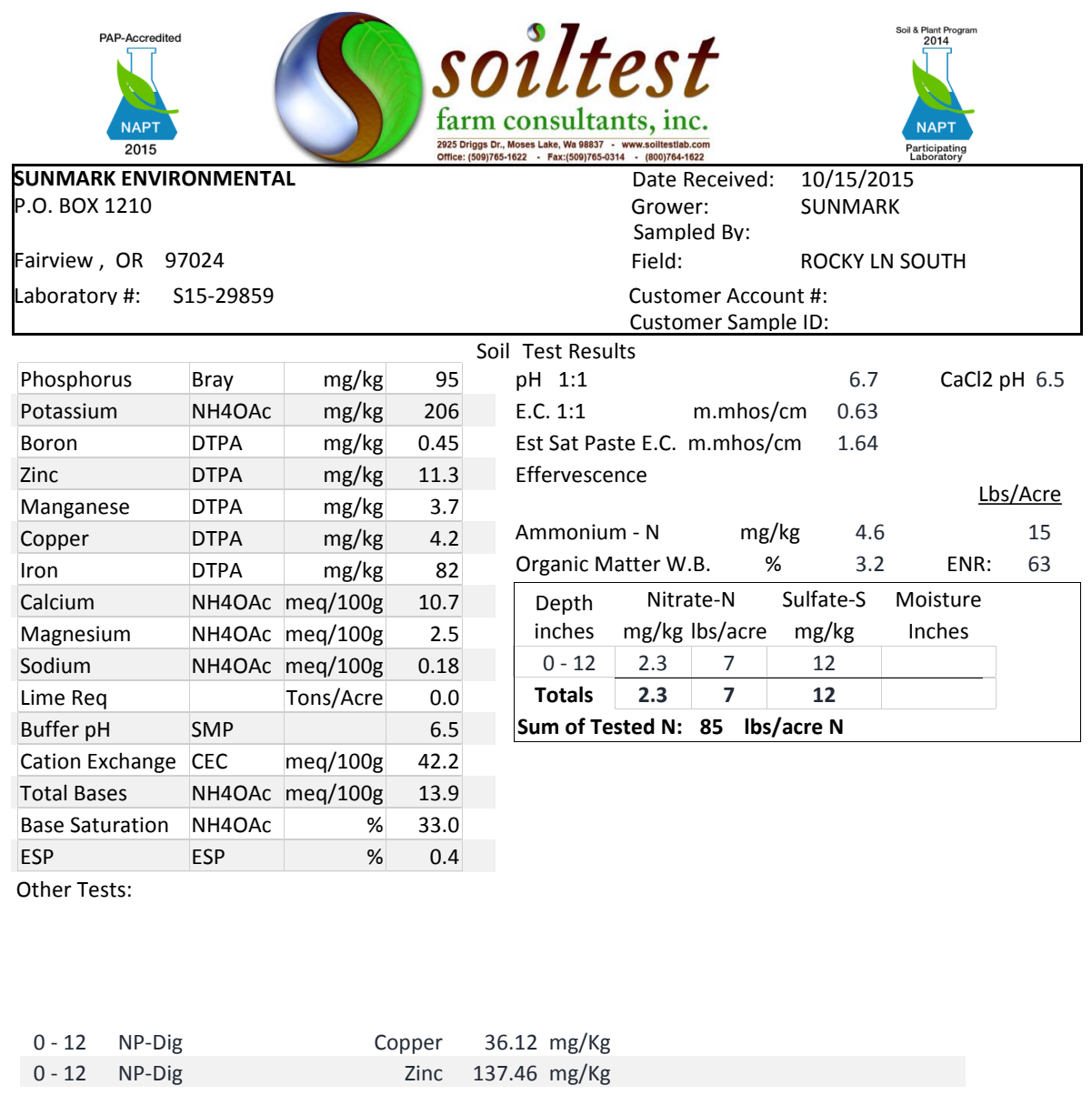

We make every effort to provide an accurate analysis of your sample. For reasonable cause we will repeat tests, but because of factors beyond our control in sampling procedures and the inherent variability of soil, our liability is limited to the price of the tests. Recommendations are to be used as general guides and should be modified for specific field conditions and situations. Note: "u" indicates that the element was analyzed for but not detected

This is your Invoice \#: S15-29859 Account \#: 301600 Reviewed by: KEB List Cost: $\$ 80.00$ 


\begin{tabular}{|l|l|l|l|l|l|}
\hline & \\
\hline
\end{tabular}

We make every effort to provide an accurate analysis of your sample. For reasonable cause we will repeat tests, but because of factors beyond our control in sampling procedures and the inherent variability of soil, our liability is limited to the price of the tests. Recommendations are to be used as general guides and should be modified for specific field conditions and situations. Note: "u" indicates that the element was analyzed for but not detected

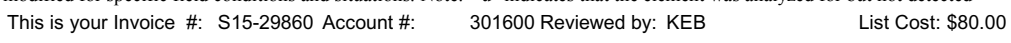




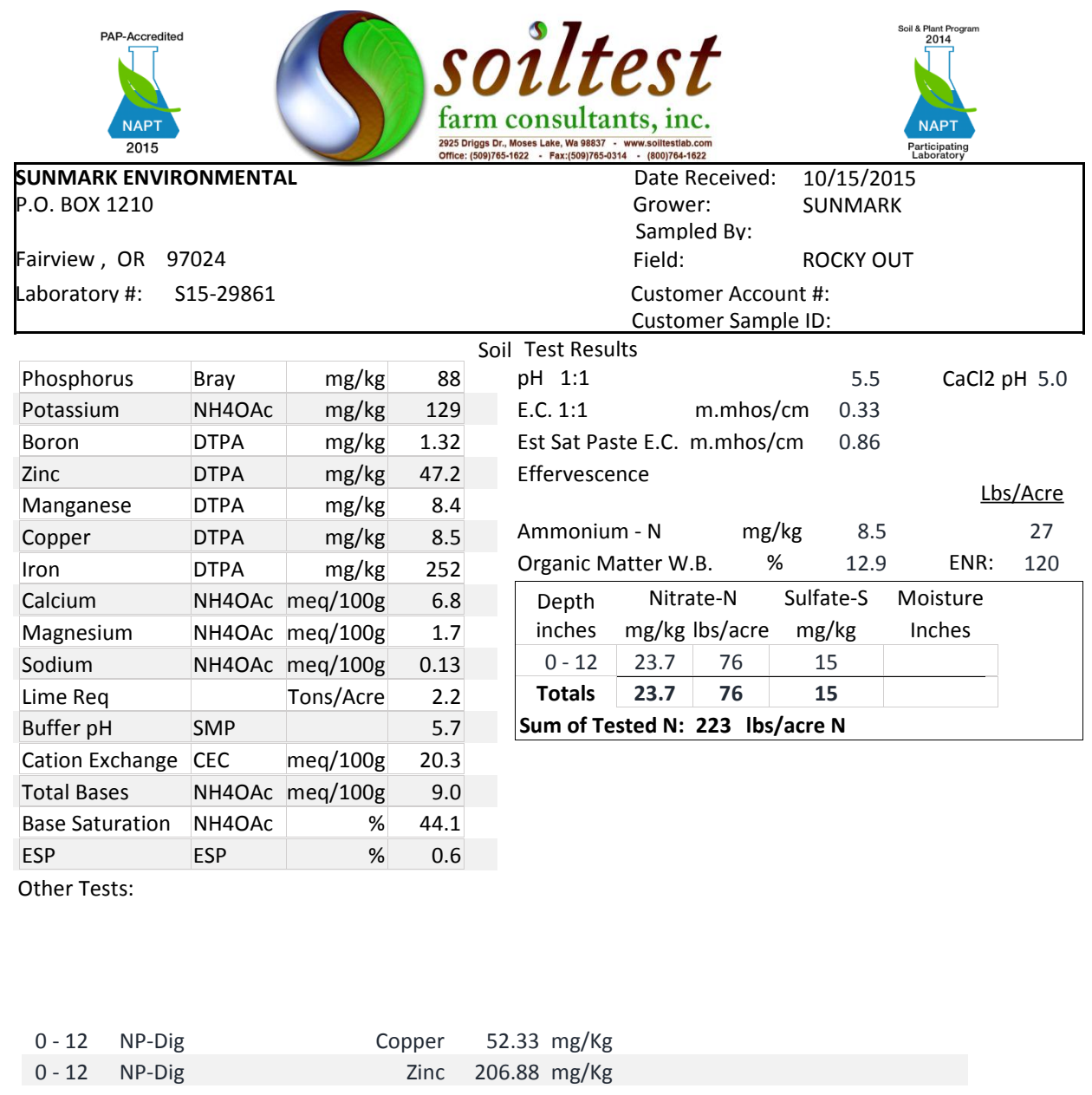

We make every effort to provide an accurate analysis of your sample. For reasonable cause we will repeat tests, but because of factors beyond our control in sampling procedures and the inherent variability of soil, our liability is limited to the price of the tests. Recommendations are to be used as general guides and should be modified for specific field conditions and situations. Note: "u" indicates that the element was analyzed for but not detected This is your Invoice \#: S15-29861 Account \#: 301600 Reviewed by: KEB List Cost: $\$ 80.00$ 
B.4 S2 Lab report for Duplo North In, collected 27 September 2015

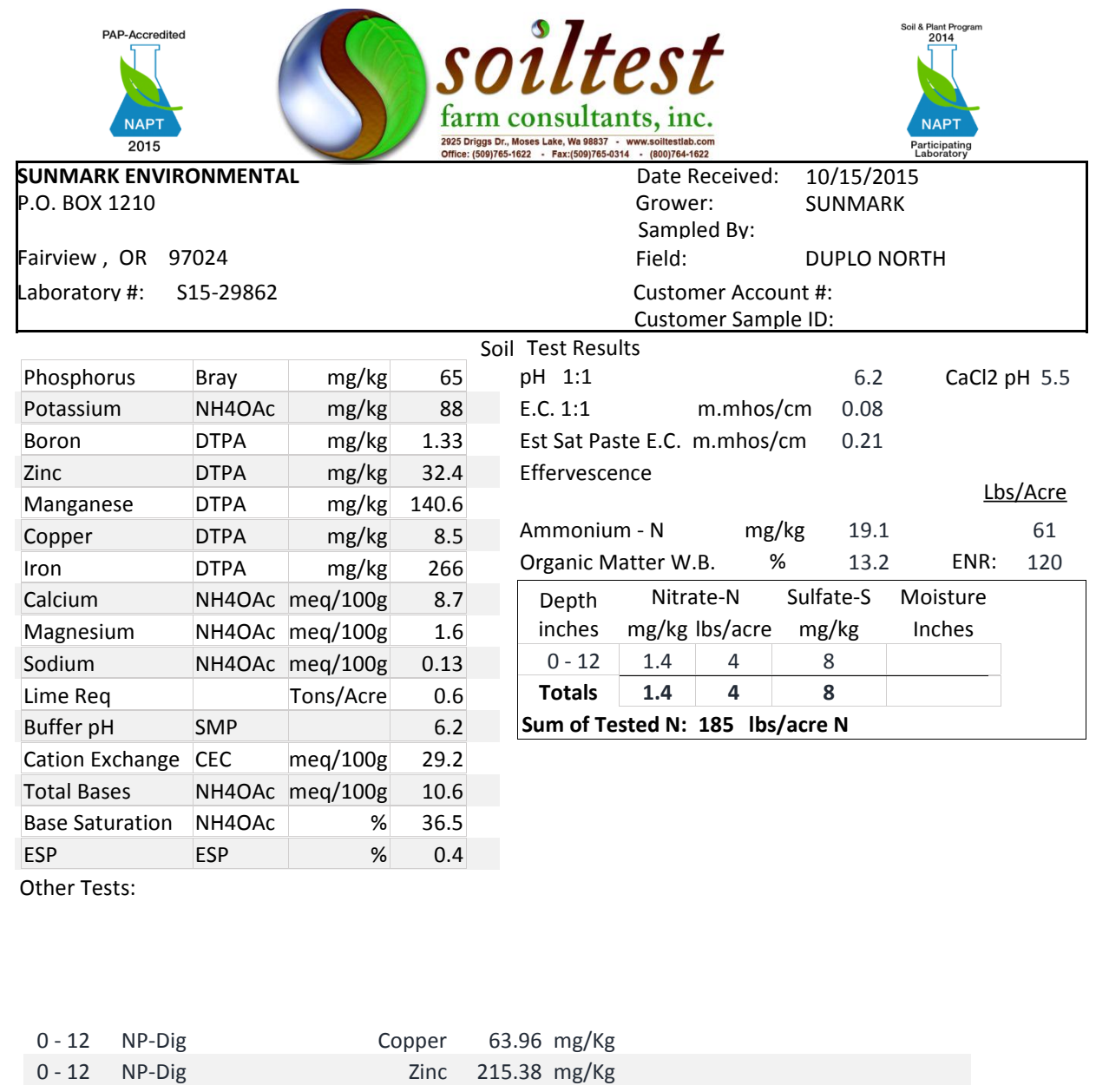

We make every effort to provide an accurate analysis of your sample. For reasonable cause we will repeat tests, but because of factors beyond our control in sampling procedures and the inherent variability of soil, our liability is limited to the price of the tests. Recommendations are to be used as general guides and should be modified for specific field conditions and situations. Note: "u" indicates that the element was analyzed for but not detected This is your Invoice \#: S15-29862 Account \#: 301600 Reviewed by: KEB List Cost: $\$ 80.00$ 


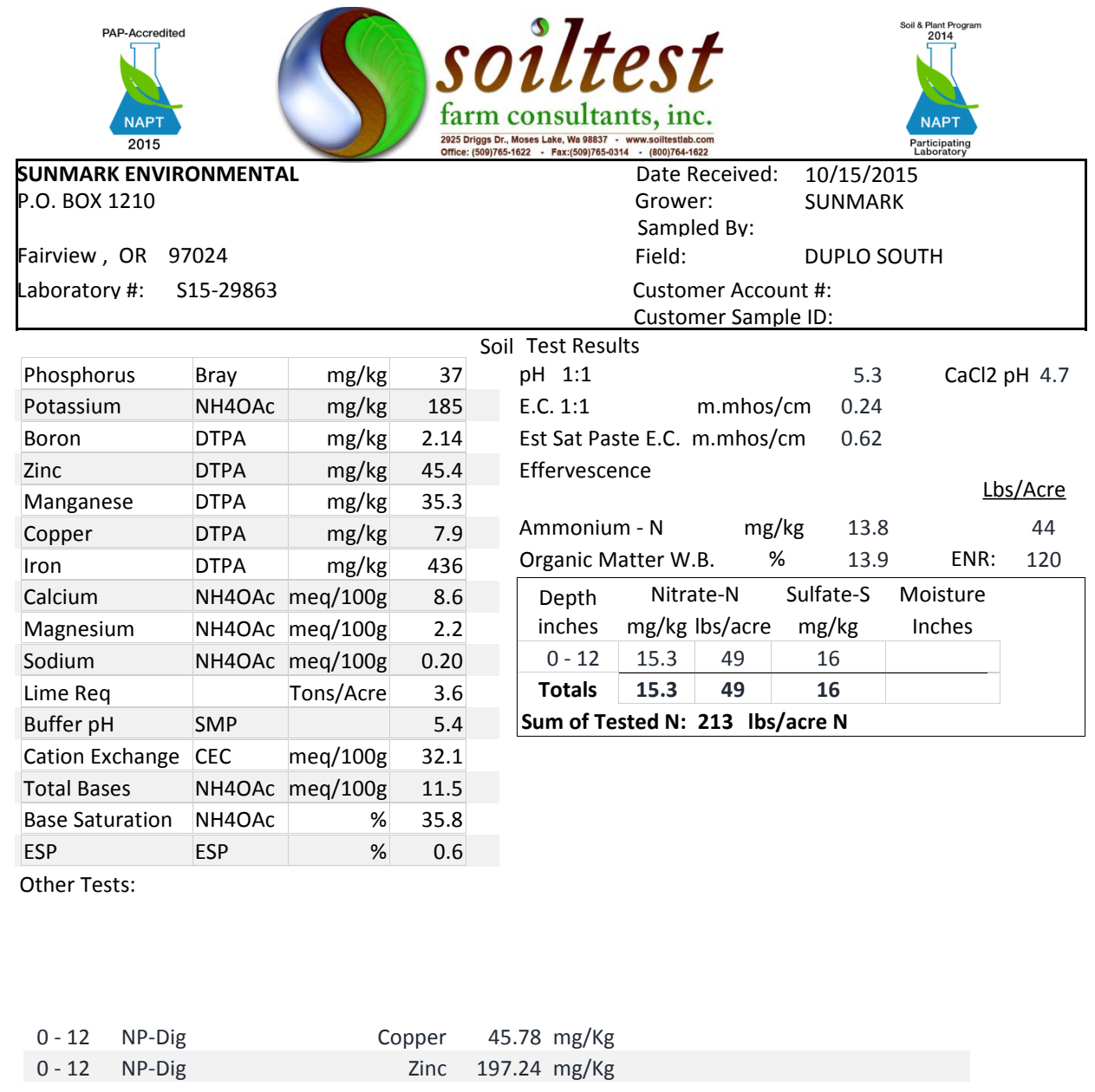

We make every effort to provide an accurate analysis of your sample. For reasonable cause we will repeat tests, but because of factors beyond our control in sampling procedures and the inherent variability of soil, our liability is limited to the price of the tests. Recommendations are to be used as general guides and should be modified for specific field conditions and situations. Note: "u" indicates that the element was analyzed for but not detected This is your Invoice \#: S15-29863 Account \#: 301600 Reviewed by: KEB List Cost: $\$ 80.00$ 


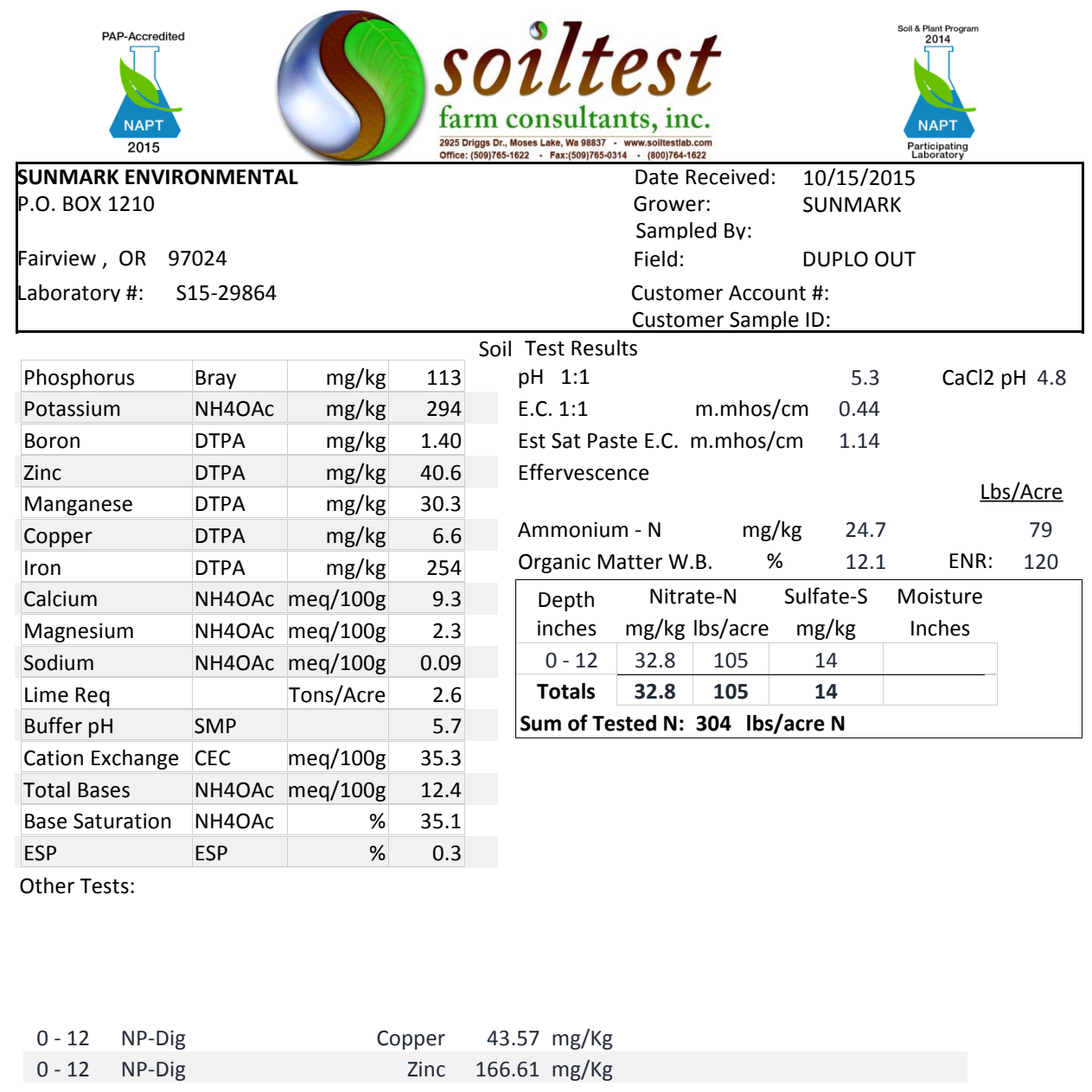

We make every effort to provide an accurate analysis of your sample. For reasonable cause we will repeat tests, but because of factors beyond our control in sampling procedures and the inherent variability of soil, our liability is limited to the price of the tests. Recommendations are to be used as general guides and should be modified for specific field conditions and situations. Note: "u" indicates that the element was analyzed for but not detected This is your Invoice \#: S15-29864 Account \#: 301600 Reviewed by: KEB List Cost: $\$ 80.00$ 
B.7 S3 Lab report for Duplo In, collected 07 November 2015

\begin{tabular}{|l|l|l|l|l|l|}
\hline & \\
\hline
\end{tabular}

We make every effort to provide an accurate analysis of your sample. For reasonable cause we will repeat tests, but because of factors beyond our control in sampling procedures and the inherent variability of soil, our liability is limited to the price of the tests. Recommendations are to be used as general guides and should be modified for specific field conditions and situations. Note: "u" indicates that the element was analyzed for but not detected This is your Invoice \#: S15-34211 Account \#: 301600 Reviewed by: KEB List Cost: $\$ 80.00$ 
B.8 S3 Lab report for Duplo Out (10m), collected 07 November 2015

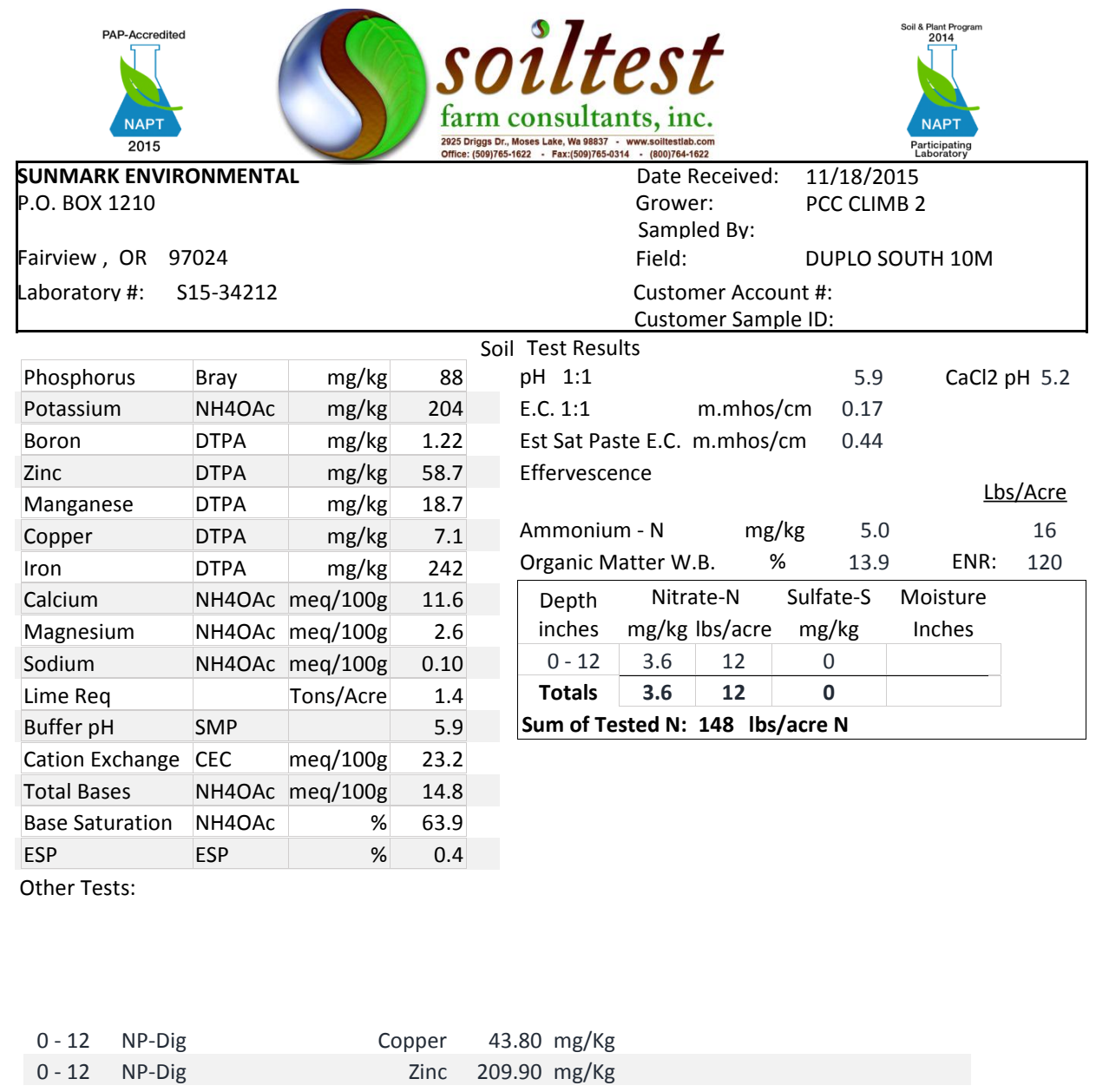

We make every effort to provide an accurate analysis of your sample. For reasonable cause we will repeat tests, but because of factors beyond our control in sampling procedures and the inherent variability of soil, our liability is limited to the price of the tests. Recommendations are to be used as general guides and should be modified for specific field conditions and situations. Note: "u" indicates that the element was analyzed for but not detected This is your Invoice \#: S15-34212 Account \#: 301600 Reviewed by: KEB List Cost: $\$ 80.00$ 


\begin{tabular}{|l|l|l|l|l|l|}
\hline & \\
\hline
\end{tabular}

We make every effort to provide an accurate analysis of your sample. For reasonable cause we will repeat tests, but because of factors beyond our control in sampling procedures and the inherent variability of soil, our liability is limited to the price of the tests. Recommendations are to be used as general guides and should be modified for specific field conditions and situations. Note: "u" indicates that the element was analyzed for but not detected

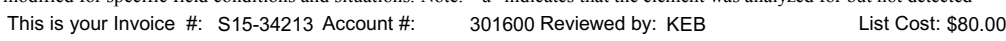


B.10 S3 Lab report for Duplo Out (20m), collected 07 November 2015

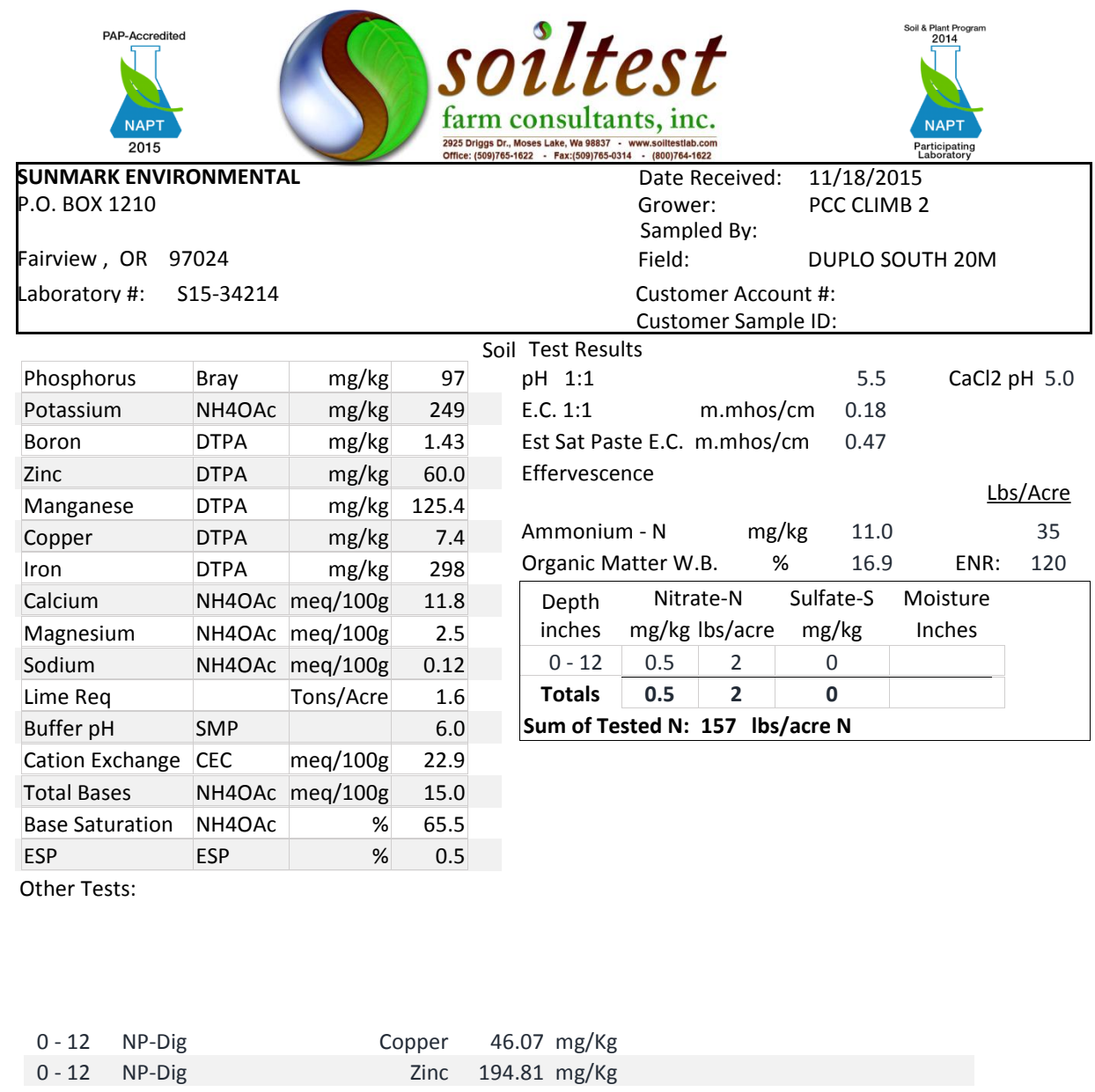

We make every effort to provide an accurate analysis of your sample. For reasonable cause we will repeat tests, but because of factors beyond our control in sampling procedures and the inherent variability of soil, our liability is limited to the price of the tests. Recommendations are to be used as general guides and should be modified for specific field conditions and situations. Note: "u" indicates that the element was analyzed for but not detected This is your Invoice \#: S15-34214 Account \#: $\quad 301600$ Reviewed by: KEB List Cost: $\$ 80.00$ 
B.11 S3 Lab report for Rocky In South, collected 07 November 2015

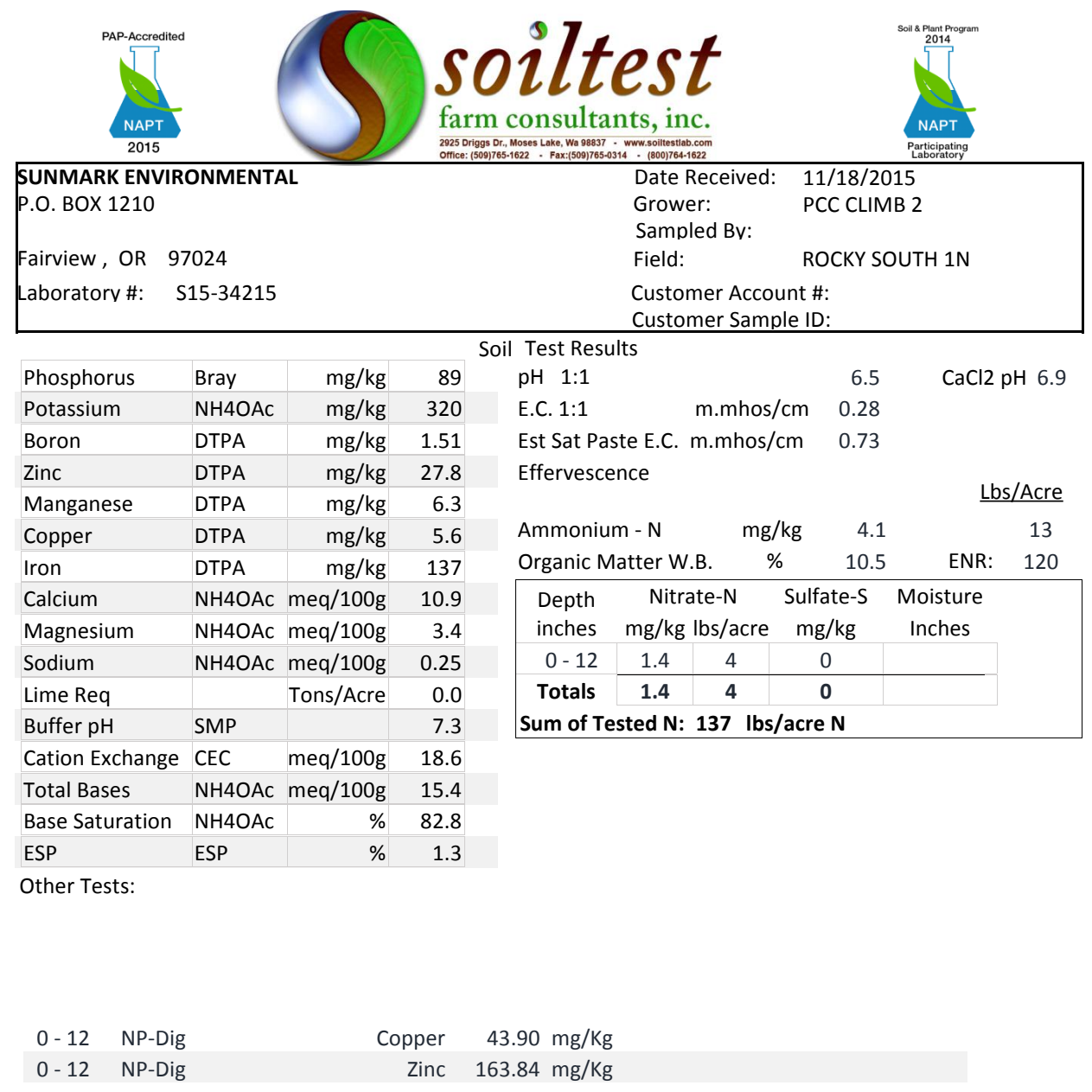

We make every effort to provide an accurate analysis of your sample. For reasonable cause we will repeat tests, but because of factors beyond our control in sampling procedures and the inherent variability of soil, our liability is limited to the price of the tests. Recommendations are to be used as general guides and should be modified for specific field conditions and situations. Note: "u" indicates that the element was analyzed for but not detected This is your Invoice \#: S15-34215 Account \#: 301600 Reviewed by: KEB List Cost: $\$ 80.00$ 
B.12 S3 Lab report for soil Rocky Out North, collected 07 November 2015

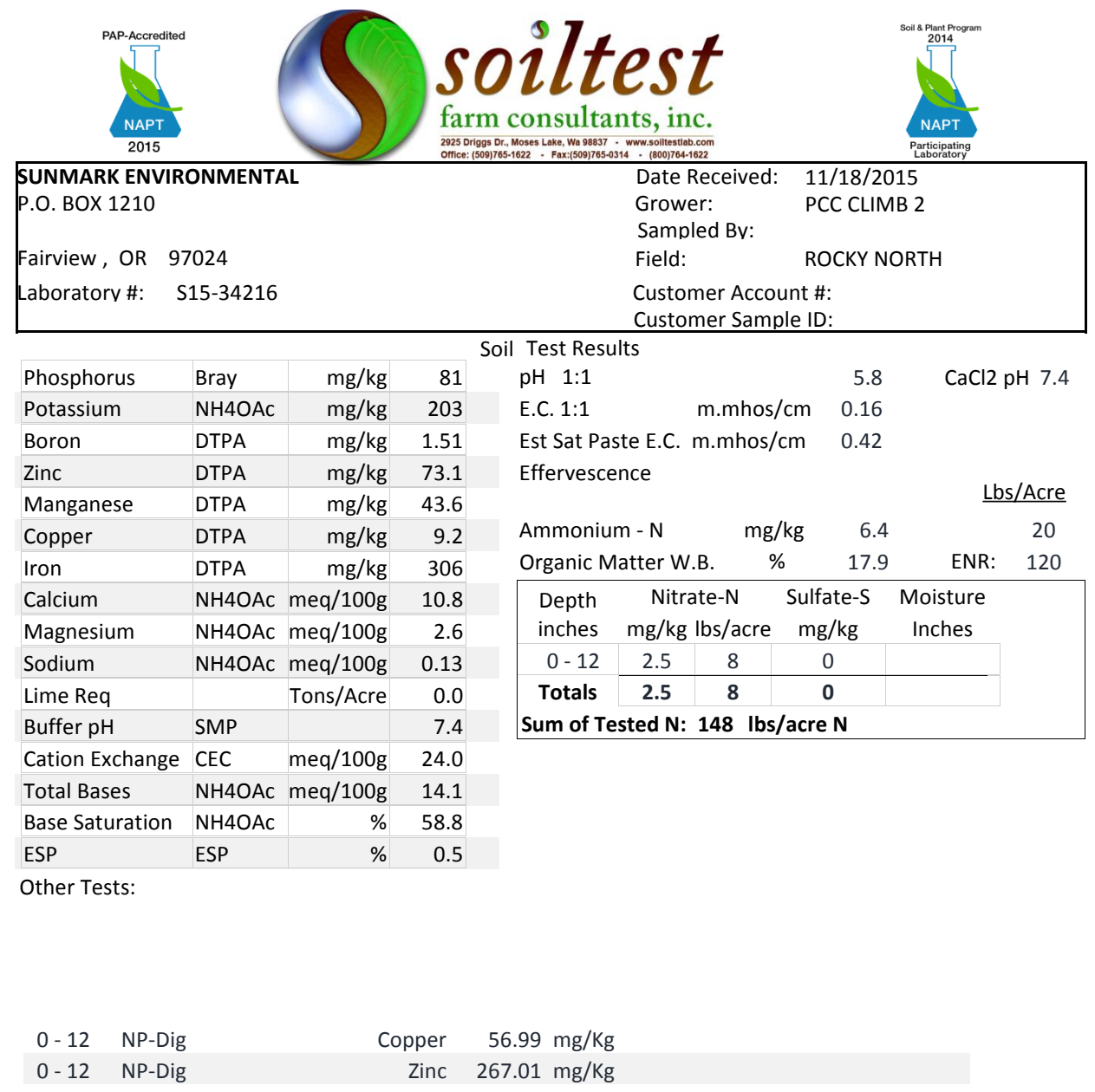

We make every effort to provide an accurate analysis of your sample. For reasonable cause we will repeat tests, but because of factors beyond our control in sampling procedures and the inherent variability of soil, our liability is limited to the price of the tests. Recommendations are to be used as general guides and should be modified for specific field conditions and situations. Note: "u" indicates that the element was analyzed for but not detected This is your Invoice \#: S15-34216 Account \#: 301600 Reviewed by: KEB List Cost: $\$ 80.00$ 
B.13 S3 Lab report for Rocky In North, collected 07 November 2015

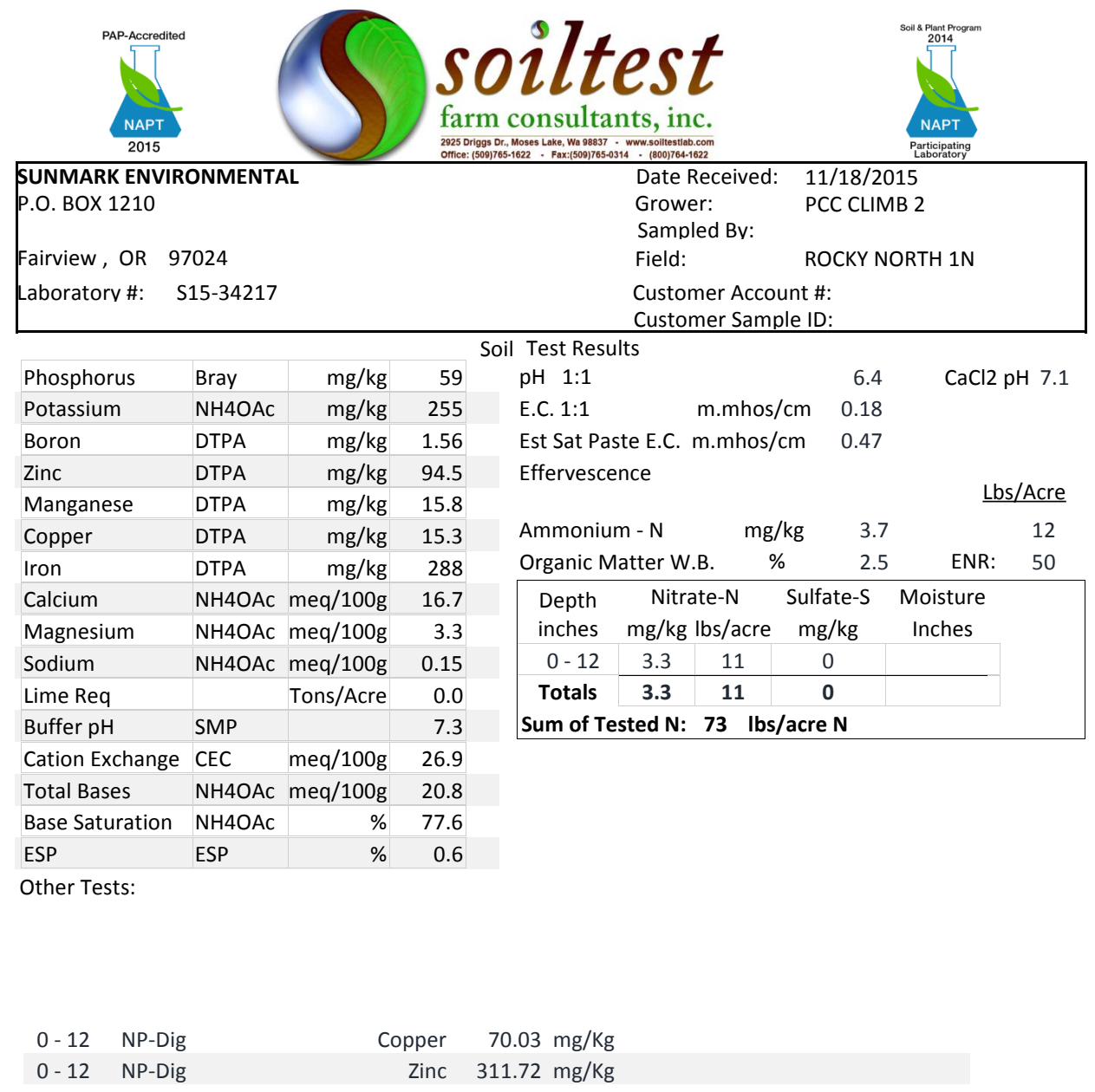

We make every effort to provide an accurate analysis of your sample. For reasonable cause we will repeat tests, but because of factors beyond our control in sampling procedures and the inherent variability of soil, our liability is limited to the price of the tests. Recommendations are to be used as general guides and should be modified for specific field conditions and situations. Note: "u" indicates that the element was analyzed for but not detected This is your Invoice \#: S15-34217 Account \#: 301600 Reviewed by: KEB List Cost: $\$ 80.00$ 
B.14 S3 Lab report for Rocky Out South, collected 07 November 2015

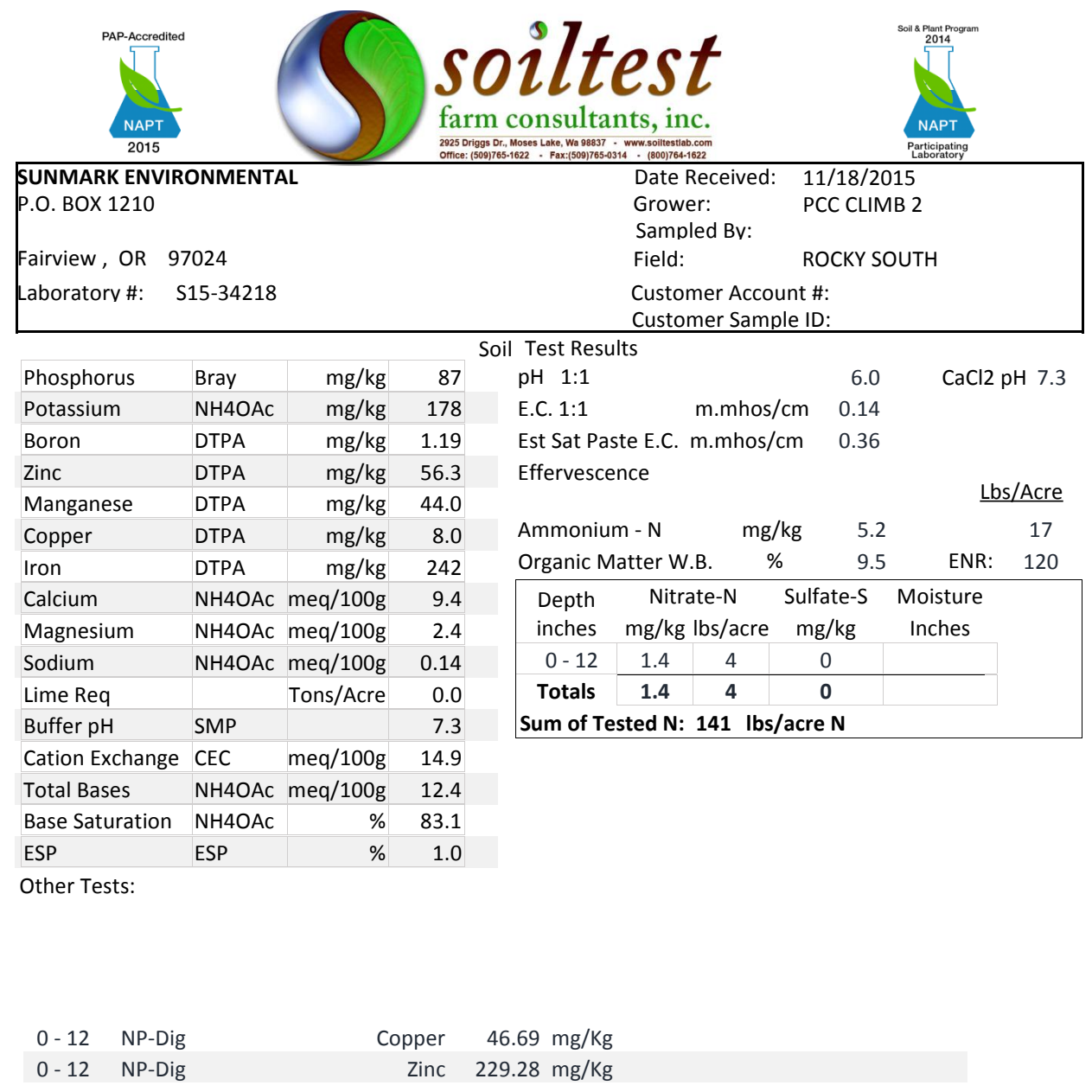

We make every effort to provide an accurate analysis of your sample. For reasonable cause we will repeat tests, but because of factors beyond our control in sampling procedures and the inherent variability of soil, our liability is limited to the price of the tests. Recommendations are to be used as general guides and should be modified for specific field conditions and situations. Note: "u" indicates that the element was analyzed for but not detected This is your Invoice \#: S15-34218 Account \#: 301600 Reviewed by: KEB List Cost: $\$ 80.00$ 
B.15 S4 Lab report for Rocky In North, collected 24 February 2016

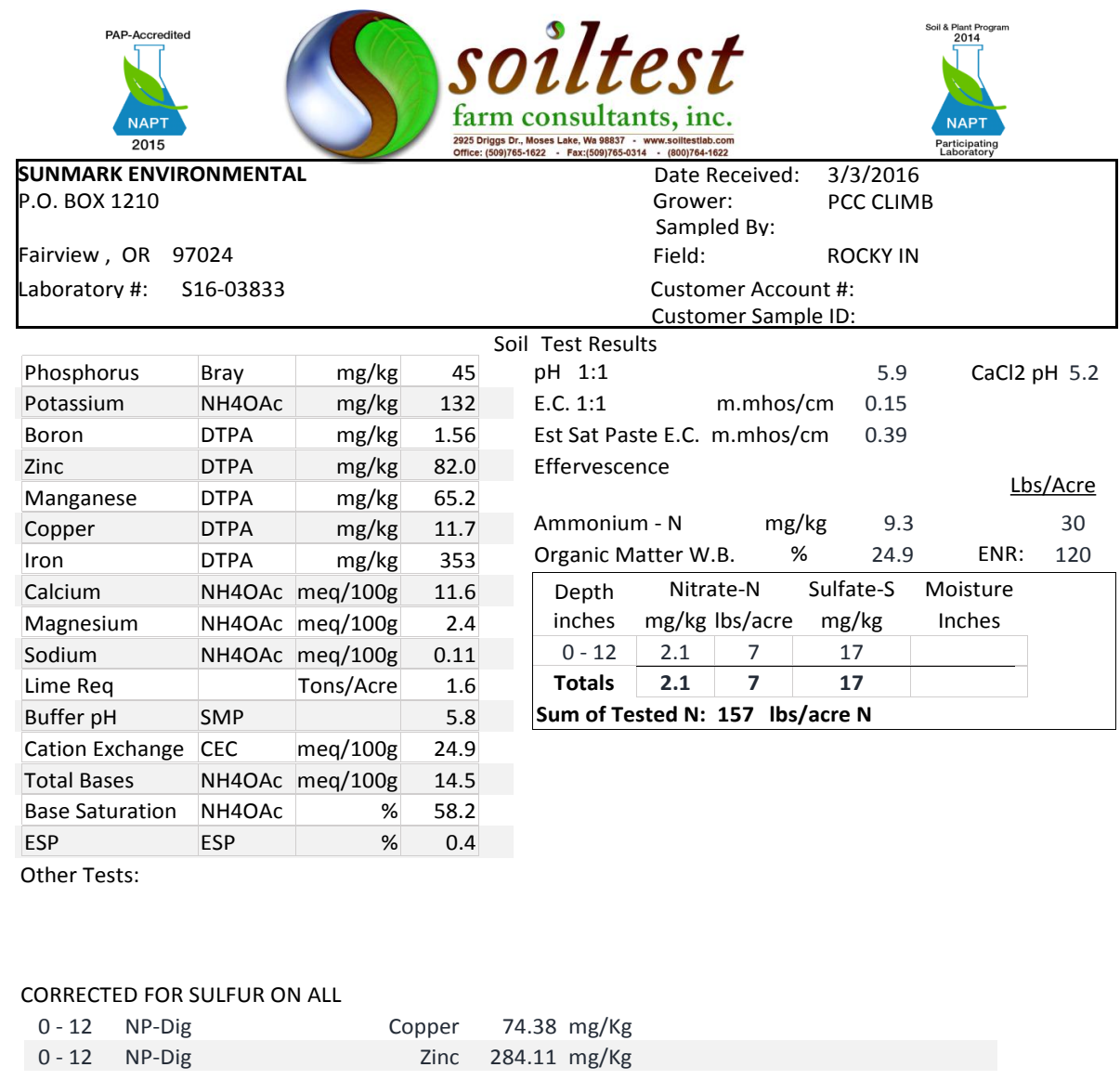

We make every effort to provide an accurate analysis of your sample. For reasonable cause we will repeat tests, but because of factors beyond our control in sampling procedures and the inherent variability of soil, our liability is limited to the price of the tests. Recommendations are to be used as general guides and should be modified for specific field conditions and situations. Note: "u" indicates that the element was analyzed for but not detected

This is your Invoice \#: S16-03833 Account \# 301600 Reviewed by: KEB List Cost: $\$ 80.00$ 
B.16 S4 Lab report for Rocky Out, collected 24 February 2016

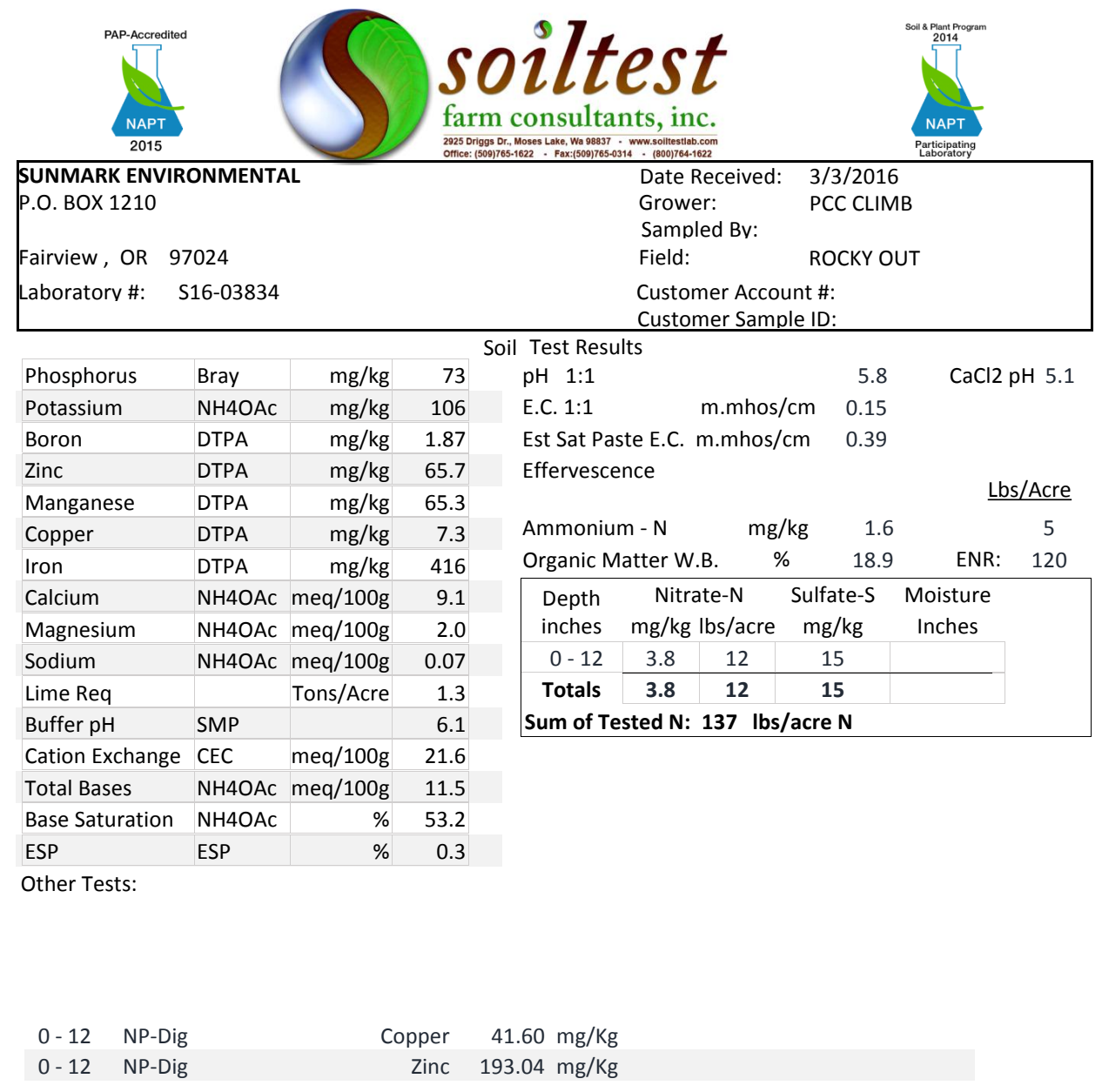

We make every effort to provide an accurate analysis of your sample. For reasonable cause we will repeat tests, but because of factors beyond our control in sampling procedures and the inherent variability of soil, our liability is limited to the price of the tests. Recommendations are to be used as general guides and should be modified for specific field conditions and situations. Note: "u" indicates that the element was analyzed for but not detected

This is your Invoice \#: S16-03834 Account \# 301600 Reviewed by: KEB List Cost: $\$ 80.00$ 


\begin{tabular}{|l|l|l|l|l|l|}
\hline & \\
\hline
\end{tabular}

We make every effort to provide an accurate analysis of your sample. For reasonable cause we will repeat tests, but because of factors beyond our control in sampling procedures and the inherent variability of soil, our liability is limited to the price of the tests. Recommendations are to be used as general guides and should be modified for specific field conditions and situations. Note: "u" indicates that the element was analyzed for but not detected
This is your Invoice \#: S16-03835 Account \# 301600
Reviewed by: KEB
List Cost: $\$ 80.00$ 
B.18 S4 Lab report for Moto In, collected 24 February 2016

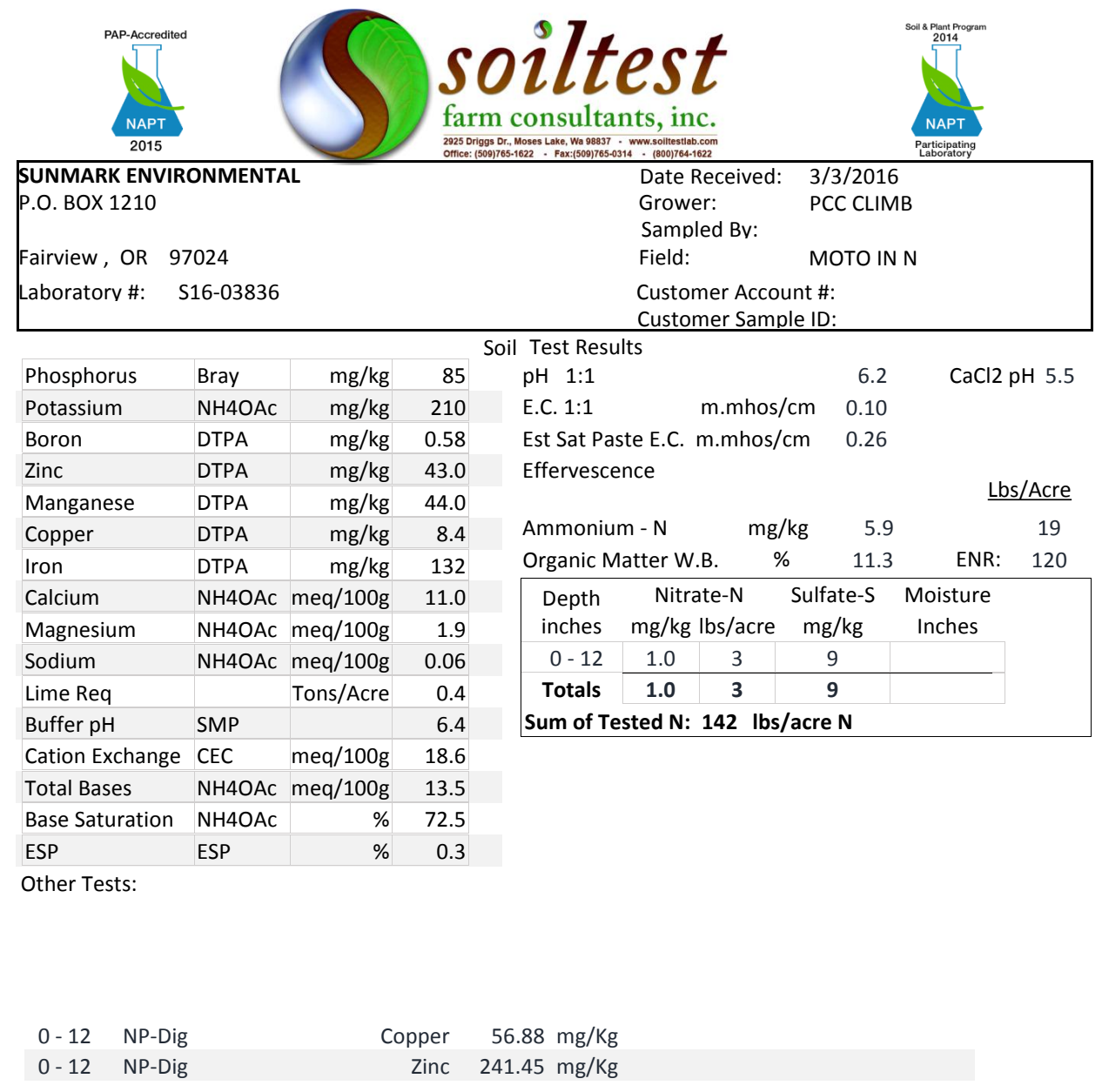

We make every effort to provide an accurate analysis of your sample. For reasonable cause we will repeat tests, but because of factors beyond our control in sampling procedures and the inherent variability of soil, our liability is limited to the price of the tests. Recommendations are to be used as general guides and should be modified for specific field conditions and situations. Note: "u" indicates that the element was analyzed for but not detected

This is your Invoice \#: S16-03836 Account \# 301600 Reviewed by: KEB List Cost: $\$ 80.00$ 


\begin{tabular}{|l|l|l|l|l|l|}
\hline & \\
\hline
\end{tabular}

We make every effort to provide an accurate analysis of your sample. For reasonable cause we will repeat tests, but because of factors beyond our control in sampling procedures and the inherent variability of soil, our liability is limited to the price of the tests. Recommendations are to be used as genera guides and should be modified for specific field conditions and situations. Note: "u" indicates that the element was analyzed for but not detected

This is your Invoice \#: S16-03837 Account \# 301600 Reviewed by: KEB List Cost: $\$ 80.00$ 


\begin{tabular}{|l|l|r|l|l|l|}
\hline & \\
\hline
\end{tabular}

We make every effort to provide an accurate analysis of your sample. For reasonable cause we will repeat tests, but because of factors beyond our control in sampling procedures and the inherent variability of soil, our liability is limited to the price of the tests. Recommendations are to be used as general guides and should be modified for specific field conditions and situations. Note: "u" indicates that the element was analyzed for but not detected
This is your Invoice \#: S16-03838 Account \# 301600
Reviewed by: KEB
List Cost: $\$ 80.00$ 


\section{Appendix C: Water sample lab reports}

C.1 Lab Report for Stormwater Sample No. 1 (page 1/6)

Pixis Labs

12423 NE Whitaker Way

Portland, OR 97230

503-254-1794

$\begin{array}{ll}\text { Job Number: } & 5121407 \\ \text { Report Date: } & 01 / 11 / 2016 \\ \text { ORELAP \#: } & \text { OR100028 }\end{array}$

Ryan Holman

Cover Letter

Sunmark Environmental

PO Box 1210

FAIRVIEW, OR 97024

Dear Ryan Holman,

Enclosed please find Pixis Labs analytical report for samples received as order number 5121407 on 12/14/2015. Should you have any questions about this report or any other matter, please do not hesitate to contact us. We are here to help you.

Test results relate only to the parameters tested and to the samples as received by the laboratory. Test results meet all requirements of NELAP and the Pixis quality assurance plan unless otherwise noted. This report shall not be reproduced, except in full, without the written consent of this laboratory. Samples will be kept a maximum of 15 days from the report date unless prior arrangements have been made.

Thank you for allowing Pixis to be of service to you, we appreciate your business.

Sincerely,

Signed

Mark Leed

Client Services 
C.2 Lab Report for Stormwater Sample No. 1 (page 2/6)

$\begin{array}{lll}\text { Pixis Labs } & \text { Job Number: } & 5121407 \\ 12423 \text { NE Whitaker } & \text { Report Date: } & 01 / 11 / 2016 \\ \text { Way } & \text { ORELAP \#: } & \text { OR100028 } \\ \text { Portland, OR } 97230 & & \\ 503-254-1794 & & \end{array}$

\begin{tabular}{|c|c|c|c|c|c|c|c|c|}
\hline \multicolumn{9}{|c|}{ Sample Results } \\
\hline \multicolumn{2}{|l|}{ Sample: Rocky N-In } & \multicolumn{4}{|c|}{ Collected: 12/12/15 10:13 } & \multicolumn{2}{|l|}{ Temp: 5 C } & $\begin{array}{l}\text { Matrix: } \\
\text { General } \\
\text { Water }\end{array}$ \\
\hline \multicolumn{2}{|l|}{ Lab ID: 98759} & \multicolumn{4}{|c|}{ Received: 12/14/15 09:10 } & \multicolumn{2}{|c|}{ Evidence of Cooling:Y } & \\
\hline Analyte & Result & Units & MRL & Dil. & Batch & Start/Extract & Analyzed & Notes \\
\hline \multicolumn{9}{|l|}{ Method: SM 4500-P-B5D } \\
\hline Total Phosphorus & 0.0590 & $\mathrm{mg} / \mathrm{L}$ & 0.0500 & 1 & $26954-16$ & 01/03/16 10:00 & 01/10/16 14:00 & \\
\hline \multicolumn{9}{|l|}{ Method: EPA 410.4} \\
\hline Chemical Oxygen Demand & ND & $\mathrm{mg} / \mathrm{L}$ & 10.0 & 1 & $26716-9$ & & $12 / 14 / 1512: 00$ & \\
\hline \multicolumn{9}{|l|}{ Method: EPA200.7 } \\
\hline Copper & ND & $\mathrm{mg} / \mathrm{L}$ & 0.0040 & 1 & $26851-18$ & $12 / 21 / 1514: 26$ & $12 / 23 / 1516: 28$ & \\
\hline Iron & 0.157 & $\mathrm{mg} / \mathrm{L}$ & 0.0080 & 1 & $26851-18$ & $12 / 21 / 1514: 26$ & $12 / 23 / 1516: 28$ & \\
\hline Lead & ND & $\mathrm{mg} / \mathrm{L}$ & 0.0080 & 1 & $26851-18$ & $12 / 21 / 1514: 26$ & $12 / 23 / 1516: 28$ & \\
\hline Zinc & 0.0135 & $\mathrm{mg} / \mathrm{L}$ & 0.0040 & 1 & $26851-18$ & $12 / 21 / 1514: 26$ & $12 / 23 / 1516: 28$ & \\
\hline \multicolumn{2}{|l|}{ Sample: Rocky N-Out } & \multicolumn{4}{|c|}{ Collected: 12/12/15 10:18 } & \multicolumn{2}{|l|}{ Temp: 5 C } & $\begin{array}{l}\text { Matrix: } \\
\text { General } \\
\text { Water }\end{array}$ \\
\hline \multicolumn{2}{|l|}{ Lab ID: 98760} & \multicolumn{4}{|c|}{ Received: $12 / 14 / 15$ 09:10 } & \multicolumn{2}{|c|}{ Evidence of Cooling:Y } & \\
\hline Analyte & Result & Units & MRL & Dil. & Batch & Start/Extract & Analyzed & Notes \\
\hline \multicolumn{9}{|l|}{ Method: SM 4500-P-B5D } \\
\hline Total Phosphorus & ND & $\mathrm{mg} / \mathrm{L}$ & 0.0500 & 1 & $26954-17$ & 01/03/16 10:00 & 01/10/16 14:00 & \\
\hline \multicolumn{9}{|l|}{ Method: EPA 410.4} \\
\hline Chemical Oxygen Demand & ND & $\mathrm{mg} / \mathrm{L}$ & 10.0 & 1 & $26785-3$ & & $12 / 21 / 1510: 00$ & \\
\hline \multicolumn{9}{|l|}{ Method: EPA200.7 } \\
\hline Copper & ND & $\mathrm{mg} / \mathrm{L}$ & 0.0040 & 1 & $26851-23$ & 12/21/15 14:26 & $12 / 23 / 1516: 40$ & \\
\hline Iron & 0.248 & $\mathrm{mg} / \mathrm{L}$ & 0.0080 & 1 & $26851-23$ & $12 / 21 / 1514: 26$ & $12 / 23 / 1516: 40$ & \\
\hline Lead & ND & $\mathrm{mg} / \mathrm{L}$ & 0.0080 & 1 & $26851-23$ & 12/21/15 14:26 & $12 / 23 / 1516: 40$ & \\
\hline Zinc & 0.0268 & $\mathrm{mg} / \mathrm{L}$ & 0.0040 & 1 & $26851-23$ & $12 / 21 / 1514: 26$ & $12 / 23 / 1516: 40$ & \\
\hline \multicolumn{2}{|l|}{ Sample: Duplo Pre } & \multicolumn{4}{|c|}{ Collected: 12/12/15 09:57 } & \multicolumn{2}{|l|}{ Temp: 5 C } & $\begin{array}{l}\text { Matrix: } \\
\text { General } \\
\text { Water }\end{array}$ \\
\hline \multicolumn{2}{|l|}{ Lab ID: 98761} & \multicolumn{4}{|c|}{ Received: $12 / 14 / 15$ 09:10 } & \multicolumn{2}{|c|}{ Evidence of Cooling:Y } & \\
\hline Analyte & Result & Units & MRL & Dil. & Batch & Start/Extract & Analyzed & Notes \\
\hline \multicolumn{9}{|l|}{ Method: SM 4500-P-B5D } \\
\hline Total Phosphorus & ND & $\mathrm{mg} / \mathrm{L}$ & 0.0500 & 1 & 26954-18 & 01/03/16 10:00 & 01/10/16 14:00 & \\
\hline Method: EPA 410.4 & & & & & & & & \\
\hline Chemical Oxygen Demand & ND & $\mathrm{mg} / \mathrm{L}$ & 10.0 & 1 & $26716-7$ & & $12 / 14 / 1512: 00$ & \\
\hline Method: EPA200.7 & & & & & & & & \\
\hline Copper & 0.0041 & $\mathrm{mg} / \mathrm{L}$ & 0.0040 & 1 & $26851-24$ & $12 / 21 / 1514: 26$ & $12 / 23 / 1516: 42$ & \\
\hline Iron & 0.365 & $\mathrm{mg} / \mathrm{L}$ & 0.0080 & 1 & $26851-24$ & $12 / 21 / 1514: 26$ & $12 / 23 / 1516: 42$ & \\
\hline Lead & ND & $\mathrm{mg} / \mathrm{L}$ & 0.0080 & 1 & $26851-24$ & $12 / 21 / 1514: 26$ & $12 / 23 / 1516: 42$ & \\
\hline Zinc & 0.0242 & $\mathrm{mg} / \mathrm{L}$ & 0.0040 & 1 & $26851-24$ & 12/21/15 14:26 & 12/23/15 16:42 & \\
\hline
\end{tabular}


C.3 Lab Report for Stormwater Sample No. 1 (page 3/6)

\begin{tabular}{|c|c|c|c|c|c|c|c|c|}
\hline \multicolumn{2}{|l|}{ Sample: Duplo 10M } & \multicolumn{4}{|c|}{ Collected: 12/12/15 10:05 } & \multicolumn{2}{|l|}{ Temp: 5 C } & \multirow{2}{*}{$\begin{array}{l}\text { Matrix: } \\
\text { General } \\
\text { Water }\end{array}$} \\
\hline Lab ID: 98762 & & Receiv & ed: $12 / 14 /$ & 15 09: & & Evidence of $\mathrm{Coc}$ & & \\
\hline Analyte & Result & Units & MRL & Dil. & Batch & Start/Extract & Analyzed & Notes \\
\hline \multicolumn{9}{|l|}{ Method: SM 4500-P-B5D } \\
\hline Total Phosphorus & ND & $\mathrm{mg} / \mathrm{L}$ & 0.0500 & 1 & $26954-19$ & 01/03/16 10:00 & $01 / 10 / 1614: 00$ & \\
\hline \multicolumn{9}{|l|}{ Method: EPA 410.4} \\
\hline Chemical Oxygen Demand & ND & $\mathrm{mg} / \mathrm{L}$ & 10.0 & 1 & $26716-8$ & & $12 / 14 / 1512: 00$ & \\
\hline \multicolumn{9}{|l|}{ Method: EPA200.7 } \\
\hline Copper & ND & $\mathrm{mg} / \mathrm{L}$ & 0.0040 & 1 & $26851-25$ & $12 / 21 / 1514: 26$ & $12 / 23 / 15$ 16:45 & \\
\hline Iron & 0.0830 & $\mathrm{mg} / \mathrm{L}$ & 0.0080 & 1 & $26851-25$ & $12 / 21 / 1514: 26$ & $12 / 23 / 1516: 45$ & \\
\hline Lead & ND & $\mathrm{mg} / \mathrm{L}$ & 0.0080 & 1 & $26851-25$ & $12 / 21 / 1514: 26$ & $12 / 23 / 1516: 45$ & \\
\hline Zinc & 0.0079 & $\mathrm{mg} / \mathrm{L}$ & 0.0040 & 1 & $26851-25$ & $12 / 21 / 1514: 26$ & $12 / 23 / 15$ 16:45 & \\
\hline
\end{tabular}

\begin{tabular}{|c|c|c|c|c|c|c|c|c|}
\hline \multicolumn{9}{|c|}{ Laboratory Quality Control Results } \\
\hline \multicolumn{9}{|l|}{ SM 4500-P-B5D } \\
\hline \multicolumn{6}{|l|}{ QC - Initial Calibration Verif. - } & \multicolumn{3}{|c|}{ Batch ID: 26954-1 } \\
\hline Analyte & Result & & Spike & Units & Recovery & Limits & RPD Limit & Notes \\
\hline Total Phosphorus & 0.528 & & 0.500 & $\mathrm{mg} / \mathrm{L}$ & $106 \%$ & $90-110$ & $---\quad \quad---$ & \\
\hline \multicolumn{6}{|c|}{ QC - Continuing Calibration Verif. - A } & \multicolumn{3}{|c|}{ Batch ID: $26954-25$} \\
\hline Analyte & Result & & Spike & Units & Recovery & Limits & RPD Limit & Notes \\
\hline Total Phosphorus & 0.521 & & 0.500 & $\mathrm{mg} / \mathrm{L}$ & $104 \%$ & $90-110$ & $---\quad---$ & \\
\hline \multicolumn{6}{|l|}{ QC - Initial Calibration Blank - } & \multicolumn{3}{|c|}{ Batch ID: $26954-2$} \\
\hline Analyte & Result & & Spike & Units & Recovery & Limits & RPD Limit & Notes \\
\hline Total Phosphorus & ND & & & $\mathrm{mg} / \mathrm{L}$ & --- & & --- - --- & \\
\hline \multicolumn{6}{|c|}{ QC - Matrix Spike - of Sample 26954 - 22} & \multicolumn{3}{|c|}{ Batch ID: 26954-23 } \\
\hline Analyte & Result & Org.Result & Spike & Units & Recovery & Limits & RPD Limit & Notes \\
\hline Total Phosphorus & 1.03 & 0.0310 & 1.00 & $\mathrm{mg} / \mathrm{L}$ & $100 \%$ & $80-120$ & $---\quad--$ & \\
\hline \multicolumn{6}{|c|}{ QC - Matrix Spike Duplicate - of Sample 26954 - 22} & \multicolumn{3}{|c|}{ Batch ID: $26954-24$} \\
\hline Analyte & Result & Org.Result & Spike & Units & Recovery & Limits & RPD Limit & Notes \\
\hline Total Phosphorus & 1.08 & 0.0310 & 1.00 & $\mathrm{mg} / \mathrm{L}$ & $105 \%$ & $80-120$ & 420 & \\
\hline \multicolumn{9}{|l|}{ EPA 410.4} \\
\hline \multicolumn{6}{|l|}{ QC - Initial Calibration Verif. - } & \multicolumn{3}{|c|}{ Batch ID: 26716-2 } \\
\hline Analyte & Result & & Spike & Units & Recovery & Limits & RPD Limit & Notes \\
\hline Chemical Oxygen Demand & 72.9 & & 75.0 & $\mathrm{mg} / \mathrm{L}$ & $97 \%$ & $90-110$ & --- $\quad$--- & \\
\hline \multicolumn{6}{|l|}{ QC - Initial Calibration Verif. - } & \multicolumn{3}{|c|}{ Batch ID: $26785-2$} \\
\hline Analyte & Result & & Spike & Units & Recovery & Limits & RPD Limit & Notes \\
\hline Chemical Oxygen Demand & 71.1 & & 75.0 & $\mathrm{mg} / \mathrm{L}$ & $95 \%$ & $90-110$ & --- $\quad$--- & \\
\hline \multicolumn{6}{|c|}{ QC - Continuing Calibration Verif. - A } & \multicolumn{3}{|c|}{ Batch ID: 26716-11 } \\
\hline Analyte & Result & & Spike & Units & Recovery & Limits & RPD Limit & Notes \\
\hline Chemical Oxygen Demand & 74.2 & & 75.0 & $\mathrm{mg} / \mathrm{L}$ & $99 \%$ & $90-110$ & $---\quad---$ & \\
\hline \multicolumn{6}{|c|}{ QC - Continuing Calibration Verif. - A } & \multicolumn{3}{|c|}{ Batch ID: $26785-14$} \\
\hline Analyte & Result & & Spike & Units & Recovery & Limits & RPD Limit & Notes \\
\hline Chemical Oxygen Demand & 71.7 & & 75.0 & $\mathrm{mg} / \mathrm{L}$ & $96 \%$ & $90-110$ & --- & \\
\hline \multicolumn{3}{|l|}{ QC - Initial Calibration Blank - } & & & & \multicolumn{3}{|c|}{ Batch ID: $26716-1$} \\
\hline Analyte & Result & & Spike & Units & Recovery & Limits & RPD Limit & Notes \\
\hline Chemical Oxygen Demand & ND & & & $\mathrm{mg} / \mathrm{L}$ & --- & --- & $---\quad$--- & \\
\hline QC - Initial Calibration Blank & & & & & & Batc & ch ID: $26785-1$ & \\
\hline Analyte & Result & & Spike & Units & Recovery & Limits & RPD Limit & Notes \\
\hline Chemical Oxygen Demand & ND & & & $\mathrm{mg} / \mathrm{L}$ & --- & & $---\quad$--- & \\
\hline QC - Matrix Spike - of Sampl & $6-3$ & & & & & Batc & ch ID: $26716-4$ & \\
\hline Analyte & Result & Org.Result & Spike & Units & Recovery & Limits & RPD Limit & Notes \\
\hline Chemical Oxygen Demand & 796 & 11.7 & 750 & $\mathrm{mg} / \mathrm{L}$ & $105 \%$ & $80-120$ & --- - --- & \\
\hline QC - Matrix Spike - of Sampl & $5-4$ & & & & & Batc & ch ID: $26785-5$ & \\
\hline Analyte & Result & Org.Result & Spike & Units & Recovery & Limits & RPD Limit & Notes \\
\hline Chemical Oxygen Demand & 748 & 0 & 750 & $\mathrm{mg} / \mathrm{L}$ & $100 \%$ & $80-120$ & --- $\quad---$ & \\
\hline QC - Matrix Spike Duplicate & mple 267 & & & & & Batc & ch ID: $26716-5$ & \\
\hline Order 5121407 & & & & & & & & $\mathrm{Pag}$ \\
\hline
\end{tabular}


C.4 Lab Report for Stormwater Sample No. 1 (page 4/6)

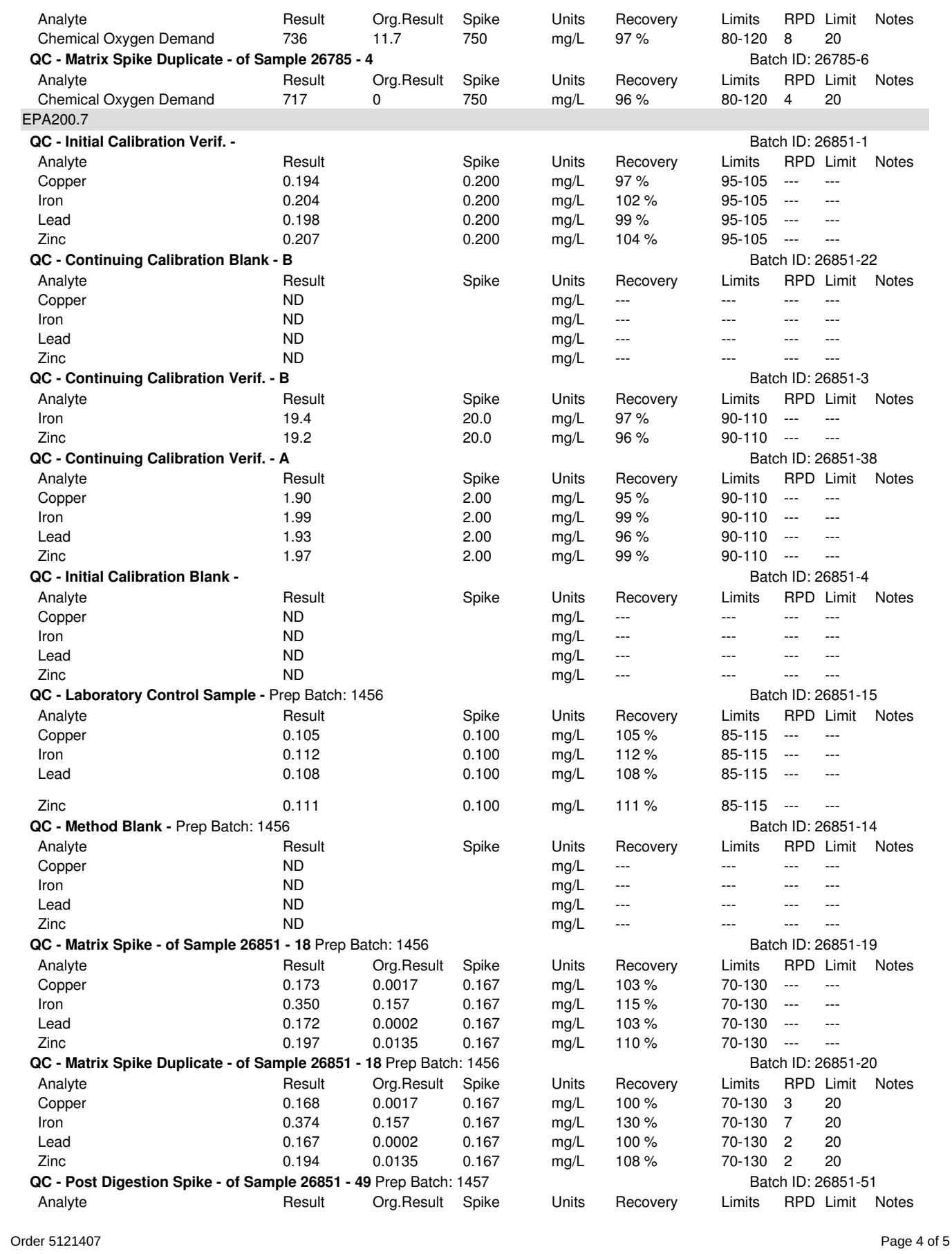


C.5 Lab Report for Stormwater Sample No. 1 (page 5/6)

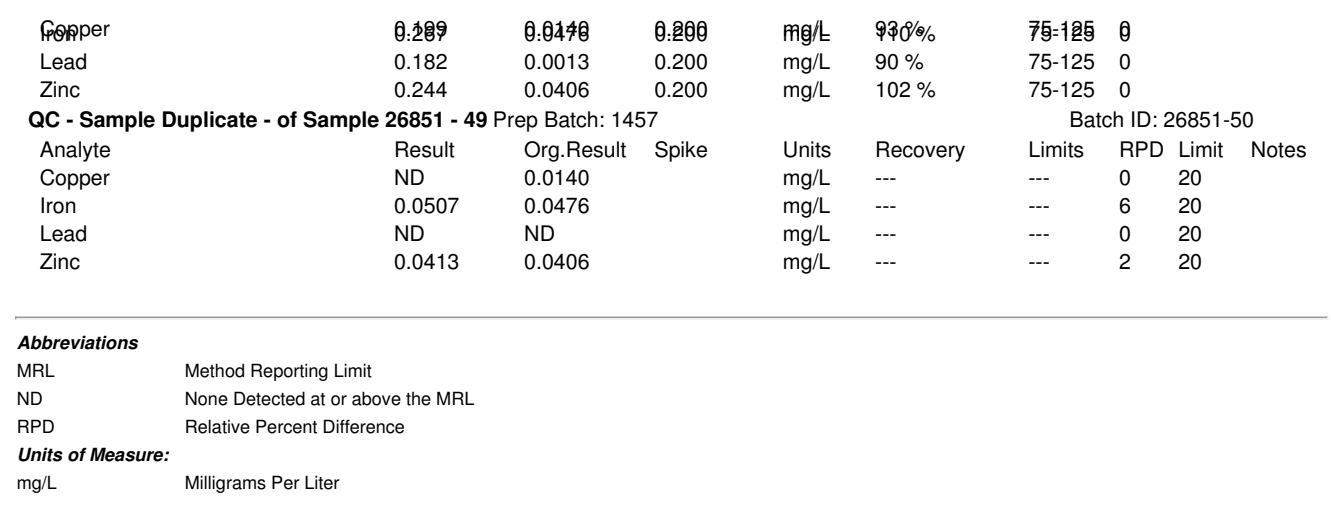




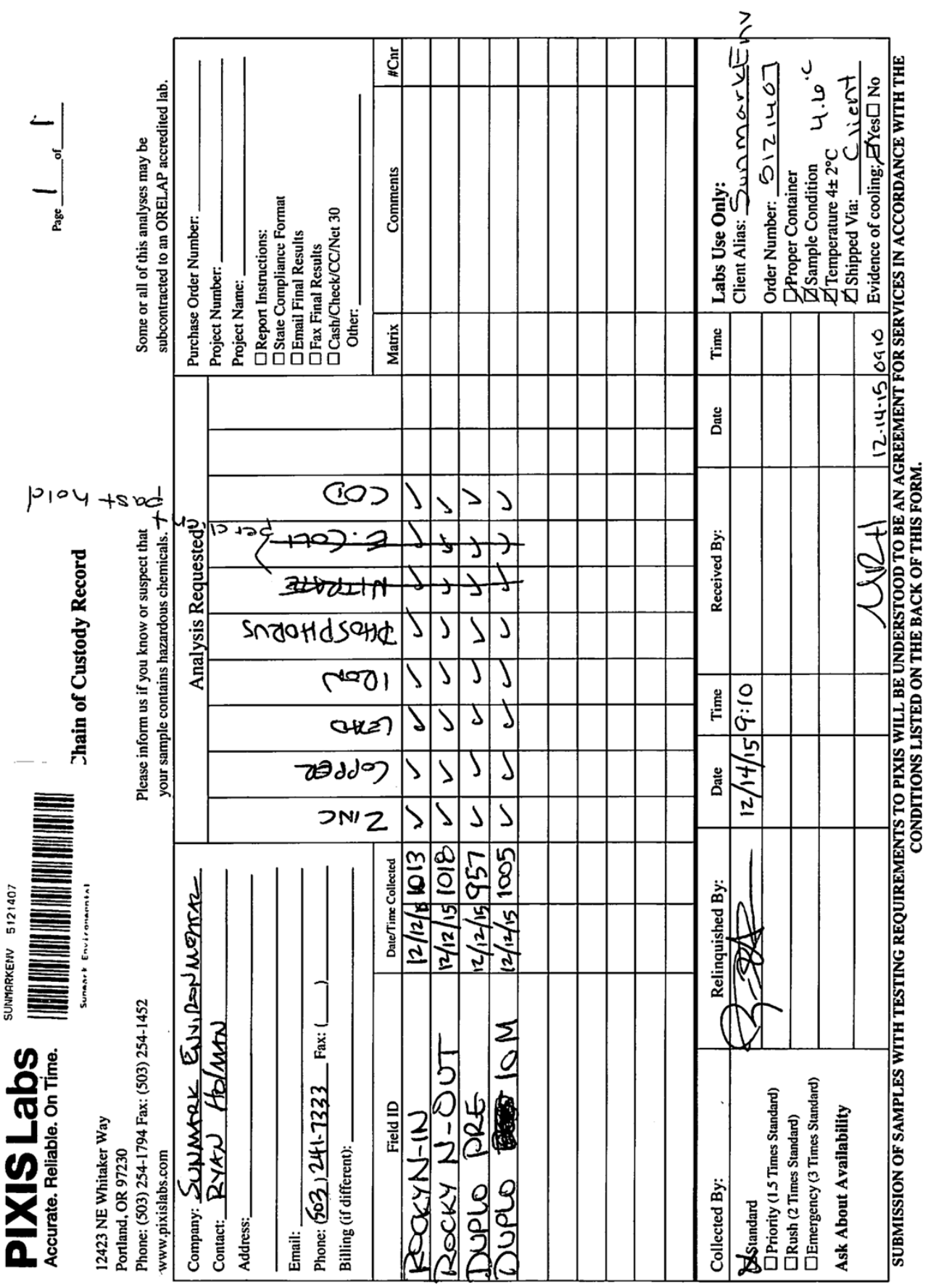


C.7 Lab Report for Stormwater Sample No. 2 (page 1/6)

Pixis Labs

12423 NE Whitaker Way

Portland, OR 97230

503-254-1794

Ryan Holman

Sunmark Environmental

PO Box 1210

FAIRVIEW, OR 97024

Dear Ryan Holman,

$\begin{array}{ll}\text { Job Number: } & 6011905 \\ \text { Report Date: } & 02 / 02 / 2016 \\ \text { ORELAP \#: } & \text { OR100028 } \\ \text { Project Name: } & 2 \\ \text { Project No: } & \text { PCC Climb }\end{array}$

\title{
Cover Letter
}

Enclosed please find Pixis Labs analytical report for samples received as order number 6011905 on 01/19/2016. Should you have any questions about this report or any other matter, please do not hesitate to contact us. We are here to help you.

Test results relate only to the parameters tested and to the samples as received by the laboratory. Test results meet all requirements of NELAP and the Pixis quality assurance plan unless otherwise noted. This report shall not be reproduced, except in full, without the written consent of this laboratory. Samples will be kept a maximum of 15 days from the report date unless prior arrangements have been made.

Thank you for allowing Pixis to be of service to you, we appreciate your business.

Sincerely,

\author{
Signed \\ Richard Reid \\ Project Manager
}


C.8 Lab Report for Stormwater Sample No. 2 (page 2/6)

$\begin{array}{lll}\text { Pixis Labs } & \text { Job Number: } & 6011905 \\ \text { 12423 NE Whitaker } & \text { Report Date: } & 02 / 02 / 2016 \\ \text { Way } & \text { ORELAP \#: } & \text { OR100028 } \\ \text { Portland, OR 97230 } & \text { Project Name: } & 2 \\ \text { 503-254-1794 } & \text { Project No: } & \text { PCC Climb }\end{array}$

\begin{tabular}{|c|c|c|c|c|c|c|c|c|}
\hline \multicolumn{9}{|c|}{ Sample Results } \\
\hline \multicolumn{2}{|l|}{ Sample: Rocky N - In } & \multicolumn{4}{|c|}{ Collected: 01/16/16 } & \multicolumn{2}{|l|}{ Temp: 8 C } & $\begin{array}{l}\text { Matrix: } \\
\text { General } \\
\text { Water }\end{array}$ \\
\hline \multicolumn{2}{|l|}{ Lab ID: 100182} & \multicolumn{4}{|c|}{ Received: 01/19/16 11:04 } & \multicolumn{2}{|c|}{ Evidence of Cooling:Y } & \\
\hline Analyte & Result & Units & MRL & Dil. & Batch & Start/Extract & Analyzed & Notes \\
\hline \multicolumn{9}{|l|}{ Method: SM 4500-P-B5D } \\
\hline Total Phosphorus & 0.147 & $\mathrm{mg} / \mathrm{L}$ & 0.0500 & 1 & $27121-17$ & 01/26/16 12:00 & $01 / 27 / 1612: 00$ & \\
\hline \multicolumn{9}{|l|}{ Method: EPA 410.4} \\
\hline Chemical Oxygen Demand & 40.3 & $\mathrm{mg} / \mathrm{L}$ & 10.0 & 1 & $27050-13$ & & 01/19/16 16:00 & \\
\hline \multicolumn{9}{|l|}{ Method: EPA200.7 } \\
\hline Copper & 0.0605 & $\mathrm{mg} / \mathrm{L}$ & 0.0040 & 1 & $27131-16$ & 01/20/16 10:49 & 01/27/16 21:50 & \\
\hline Iron & 9.98 & $\mathrm{mg} / \mathrm{L}$ & 0.0800 & 10 & $27171-14$ & 01/20/16 10:49 & 02/01/16 12:26 & \\
\hline Lead & 0.0338 & $\mathrm{mg} / \mathrm{L}$ & 0.0040 & 1 & $27131-16$ & 01/20/16 10:49 & $01 / 27 / 1621: 50$ & \\
\hline Zinc & 0.291 & $\mathrm{mg} / \mathrm{L}$ & 0.0040 & 1 & $27131-16$ & 01/20/16 10:49 & $01 / 27 / 1621: 50$ & \\
\hline \multicolumn{2}{|l|}{ Sample: Rocky N - Out } & \multicolumn{4}{|c|}{ Collected: 01/16/16 } & \multicolumn{2}{|l|}{ Temp: 8 C } & $\begin{array}{l}\text { Matrix: } \\
\text { General } \\
\text { Water }\end{array}$ \\
\hline \multicolumn{2}{|l|}{ Lab ID: 100183} & \multicolumn{4}{|c|}{ Received: 01/19/16 11:04 } & \multicolumn{2}{|c|}{ Evidence of Cooling:Y } & \\
\hline Analyte & Result & Units & MRL & Dil. & Batch & Start/Extract & Analyzed & Notes \\
\hline \multicolumn{9}{|l|}{ Method: SM 4500-P-B5D } \\
\hline Total Phosphorus & 0.119 & $\mathrm{mg} / \mathrm{L}$ & 0.0500 & 1 & $27121-18$ & 01/26/16 12:00 & 01/27/16 12:00 & \\
\hline \multicolumn{9}{|l|}{ Method: EPA 410.4} \\
\hline Chemical Oxygen Demand & 25.4 & $\mathrm{mg} / \mathrm{L}$ & 10.0 & 1 & $27050-14$ & & 01/19/16 16:00 & \\
\hline \multicolumn{9}{|l|}{ Method: EPA200.7 } \\
\hline Copper & ND & $\mathrm{mg} / \mathrm{L}$ & 0.0040 & 1 & $27171-15$ & 01/20/16 10:49 & 02/01/16 12:36 & \\
\hline Iron & 0.667 & $\mathrm{mg} / \mathrm{L}$ & 0.0080 & 1 & $27171-15$ & 01/20/16 10:49 & 02/01/16 12:36 & \\
\hline Lead & ND & $\mathrm{mg} / \mathrm{L}$ & 0.0080 & 1 & $27171-15$ & 01/20/16 10:49 & 02/01/16 12:36 & \\
\hline Zinc & 0.0278 & $\mathrm{mg} / \mathrm{L}$ & 0.0200 & 1 & $27171-15$ & 01/20/16 10:49 & 02/01/16 12:36 & \\
\hline \multicolumn{2}{|l|}{ Sample: Duplo In/Pre } & \multicolumn{4}{|c|}{ Collected: 01/16/16 } & \multicolumn{2}{|l|}{ Temp: 8 C } & $\begin{array}{l}\text { Matrix: } \\
\text { General } \\
\text { Water }\end{array}$ \\
\hline \multicolumn{2}{|l|}{ Lab ID: 100184} & \multicolumn{4}{|c|}{ Received: 01/19/16 11:04 } & \multicolumn{2}{|c|}{ Evidence of Cooling:Y } & \\
\hline Analyte & Result & Units & MRL & Dil. & Batch & Start/Extract & Analyzed & Notes \\
\hline \multicolumn{9}{|l|}{ Method: SM 4500-P-B5D } \\
\hline Total Phosphorus & 0.0900 & $\mathrm{mg} / \mathrm{L}$ & 0.0500 & 1 & $27121-19$ & 01/26/16 12:00 & 01/27/16 12:00 & \\
\hline Method: EPA 410.4 & & & & & & & & \\
\hline Chemical Oxygen Demand & 16.9 & $\mathrm{mg} / \mathrm{L}$ & 10.0 & 1 & $27050-15$ & & 01/19/16 16:00 & \\
\hline Method: EPA200.7 & & & & & & & & \\
\hline Copper & 0.0051 & $\mathrm{mg} / \mathrm{L}$ & 0.0040 & 1 & $27171-16$ & 01/20/16 10:49 & 02/01/16 12:40 & \\
\hline Iron & 1.33 & $\mathrm{mg} / \mathrm{L}$ & 0.0080 & 1 & $27171-16$ & 01/20/16 10:49 & 02/01/16 12:40 & \\
\hline Lead & ND & $\mathrm{mg} / \mathrm{L}$ & 0.0080 & 1 & $27171-16$ & 01/20/16 10:49 & 02/01/16 12:40 & \\
\hline Zinc & 0.0327 & $\mathrm{mg} / \mathrm{L}$ & 0.0200 & 1 & 27171-16 & 01/20/16 10:49 & 02/01/16 12:40 & \\
\hline
\end{tabular}


C.9 Lab Report for Stormwater Sample No. 2 (page 3/6)

\begin{tabular}{|c|c|c|c|c|c|c|c|c|}
\hline \multirow{2}{*}{$\begin{array}{l}\text { Sample: Duplo IOM } \\
\text { Lab ID: } 100185\end{array}$} & \multirow[b]{3}{*}{ Result } & \multicolumn{4}{|c|}{ Collected: 01/16/16 } & \multicolumn{2}{|l|}{ Temp: $8 \mathrm{C}$} & \multirow{3}{*}{$\begin{array}{l}\text { Matrix: } \\
\text { Genera } \\
\text { Water } \\
\text { Notes }\end{array}$} \\
\hline & & \multicolumn{4}{|c|}{ Received: 01/19/16 11:04 } & \multicolumn{2}{|c|}{ Evidence of Cooling:Y } & \\
\hline Analyte & & Units & MRL & Dil. & Batch & Start/Extract & Analyzed & \\
\hline \multicolumn{9}{|l|}{ Method: SM 4500-P-B5D } \\
\hline Total Phosphorus & 0.124 & $\mathrm{mg} / \mathrm{L}$ & 0.0500 & 1 & $27121-20$ & 01/26/16 12:00 & 01/27/16 12:00 & \\
\hline \multicolumn{9}{|l|}{ Method: EPA 410.4} \\
\hline Chemical Oxygen Demand & ND & $\mathrm{mg} / \mathrm{L}$ & 10.0 & 1 & $27050-16$ & & 01/19/16 16:00 & \\
\hline \multicolumn{9}{|l|}{ Method: EPA200.7 } \\
\hline Copper & ND & $\mathrm{mg} / \mathrm{L}$ & 0.0040 & 1 & $27171-17$ & 01/20/16 10:49 & 02/01/16 12:43 & \\
\hline Iron & 0.163 & $\mathrm{mg} / \mathrm{L}$ & 0.0080 & 1 & $27171-17$ & $01 / 20 / 1610: 49$ & $02 / 01 / 1612: 43$ & \\
\hline Lead & ND & $\mathrm{mg} / \mathrm{L}$ & 0.0080 & 1 & $27171-17$ & 01/20/16 10:49 & $02 / 01 / 1612: 43$ & \\
\hline Zinc & ND & $\mathrm{mg} / \mathrm{L}$ & 0.0200 & 1 & $27171-17$ & 01/20/16 10:49 & $02 / 01 / 1612: 43$ & \\
\hline Sample: Moto & & \multicolumn{4}{|c|}{ Collected: 01/16/16 } & \multicolumn{2}{|l|}{ Temp: 8 C } & $\begin{array}{l}\text { Matrix: } \\
\text { General } \\
\text { Water }\end{array}$ \\
\hline Lab ID: 100186 & & \multicolumn{4}{|c|}{ Received: 01/19/16 11:04 } & \multicolumn{2}{|c|}{ Evidence of Cooling:Y } & \\
\hline Analyte & Result & Units & MRL & Dil. & Batch & Start/Extract & Analyzed & Notes \\
\hline \multicolumn{9}{|l|}{ Method: SM 4500-P-B5D } \\
\hline Total Phosphorus & 0.125 & $\mathrm{mg} / \mathrm{L}$ & 0.0500 & 1 & $27121-21$ & 01/26/16 12:00 & $01 / 27 / 1612: 00$ & \\
\hline \multicolumn{9}{|l|}{ Method: EPA 410.4} \\
\hline Chemical Oxygen Demand & ND & $\mathrm{mg} / \mathrm{L}$ & 10.0 & 1 & $27050-19$ & & 01/19/16 16:00 & \\
\hline \multicolumn{9}{|l|}{ Method: EPA200.7 } \\
\hline Copper & ND & $\mathrm{mg} / \mathrm{L}$ & 0.0040 & 1 & $27171-18$ & $01 / 20 / 1610: 49$ & $02 / 01 / 1612: 46$ & \\
\hline Iron & 0.246 & $\mathrm{mg} / \mathrm{L}$ & 0.0080 & 1 & $27171-18$ & 01/20/16 10:49 & $02 / 01 / 1612: 46$ & \\
\hline Lead & ND & $\mathrm{mg} / \mathrm{L}$ & 0.0080 & 1 & $27171-18$ & 01/20/16 10:49 & $02 / 01 / 1612: 46$ & \\
\hline Zinc & 0.0258 & $\mathrm{mg} / \mathrm{L}$ & 0.0200 & 1 & $27171-18$ & $01 / 20 / 1610: 49$ & $02 / 01 / 1612: 46$ & \\
\hline Sample: Moto In & & \multicolumn{4}{|c|}{ Collected: 01/16/16 } & \multicolumn{2}{|l|}{ Temp: 8 C } & $\begin{array}{l}\text { Matrix: } \\
\text { General } \\
\text { Water }\end{array}$ \\
\hline Lab ID: 100187 & & \multicolumn{4}{|c|}{ Received: 01/19/16 11:04 } & \multicolumn{2}{|c|}{ Evidence of Cooling:Y } & \\
\hline Analyte & Result & Units & MRL & Dil. & Batch & Start/Extract & Analyzed & Notes \\
\hline \multicolumn{9}{|l|}{ Method: SM 4500-P-B5D } \\
\hline Total Phosphorus & 0.522 & $\mathrm{mg} / \mathrm{L}$ & 0.0500 & 1 & $27121-24$ & 01/26/16 12:00 & $01 / 27 / 1612: 00$ & \\
\hline \multicolumn{9}{|l|}{ Method: EPA 410.4} \\
\hline Chemical Oxygen Demand & 340 & $\mathrm{mg} / \mathrm{L}$ & 50.0 & 5 & $27114-3$ & & 01/26/16 11:00 & \\
\hline \multicolumn{9}{|l|}{ Method: EPA200.7 } \\
\hline Copper & 0.0215 & $\mathrm{mg} / \mathrm{L}$ & 0.0040 & 1 & $27171-19$ & 01/20/16 10:49 & $02 / 01 / 1612: 50$ & \\
\hline Iron & 3.93 & $\mathrm{mg} / \mathrm{L}$ & 0.0080 & 1 & $27171-19$ & 01/20/16 10:49 & 02/01/16 12:50 & \\
\hline Lead & 0.0126 & $\mathrm{mg} / \mathrm{L}$ & 0.0080 & 1 & $27171-19$ & $01 / 20 / 1610: 49$ & $02 / 01 / 1612: 50$ & \\
\hline Zinc & 0.119 & $\mathrm{mg} / \mathrm{L}$ & 0.0200 & 1 & $27171-19$ & 01/20/16 10:49 & 02/01/16 12:50 & \\
\hline
\end{tabular}

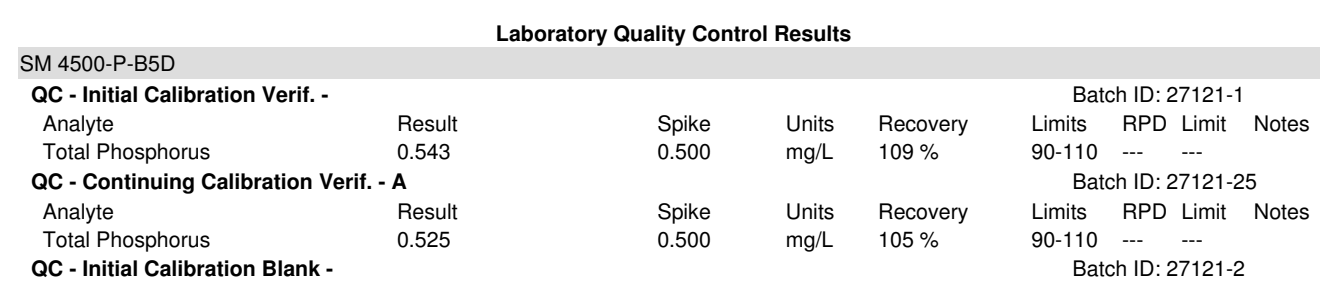

Order 6011905 
C.10 Lab Report for Stormwater Sample No. 2 (page 4/6)

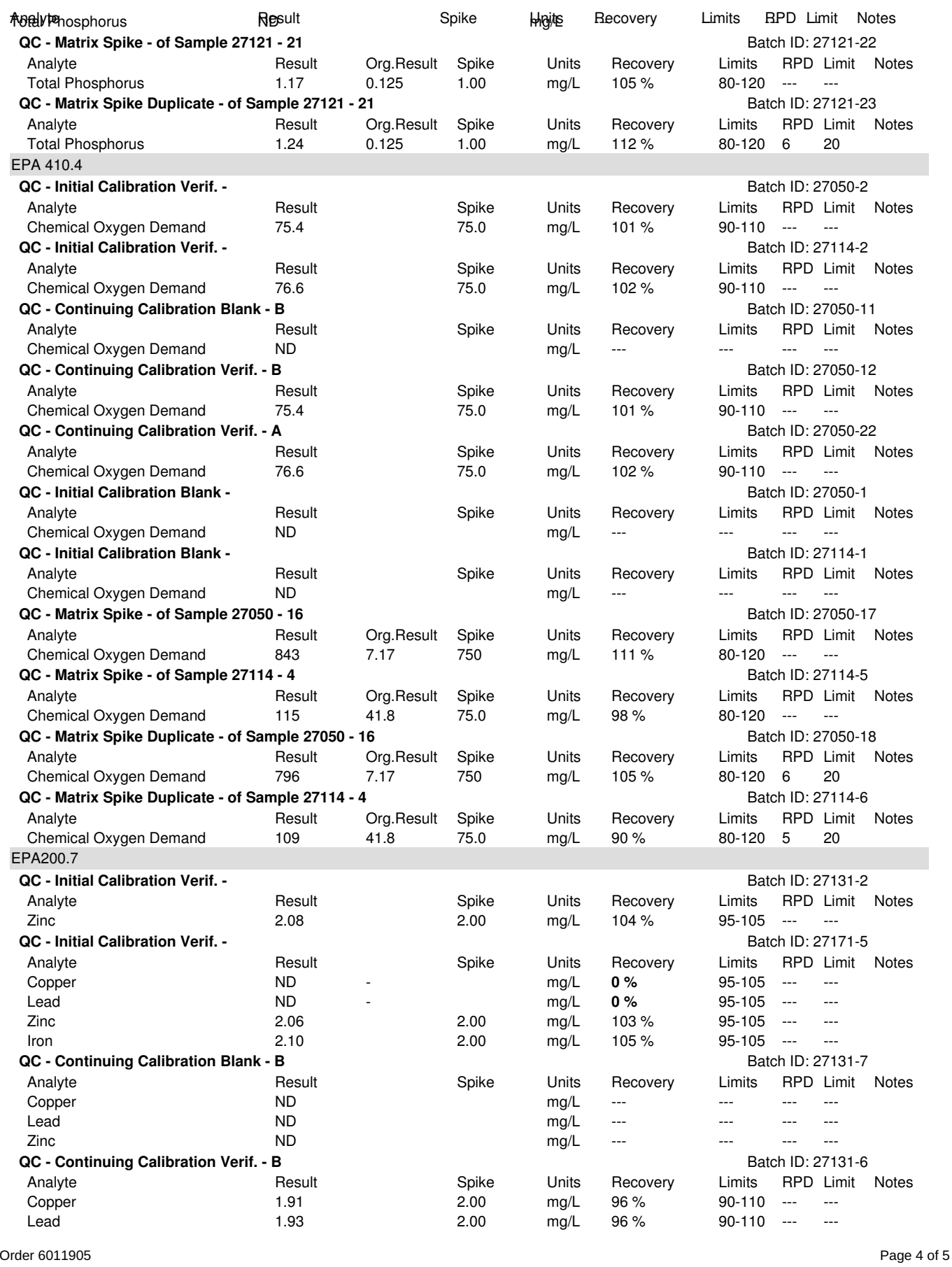


C.11 Lab Report for Stormwater Sample No. 2 (page 5/6)

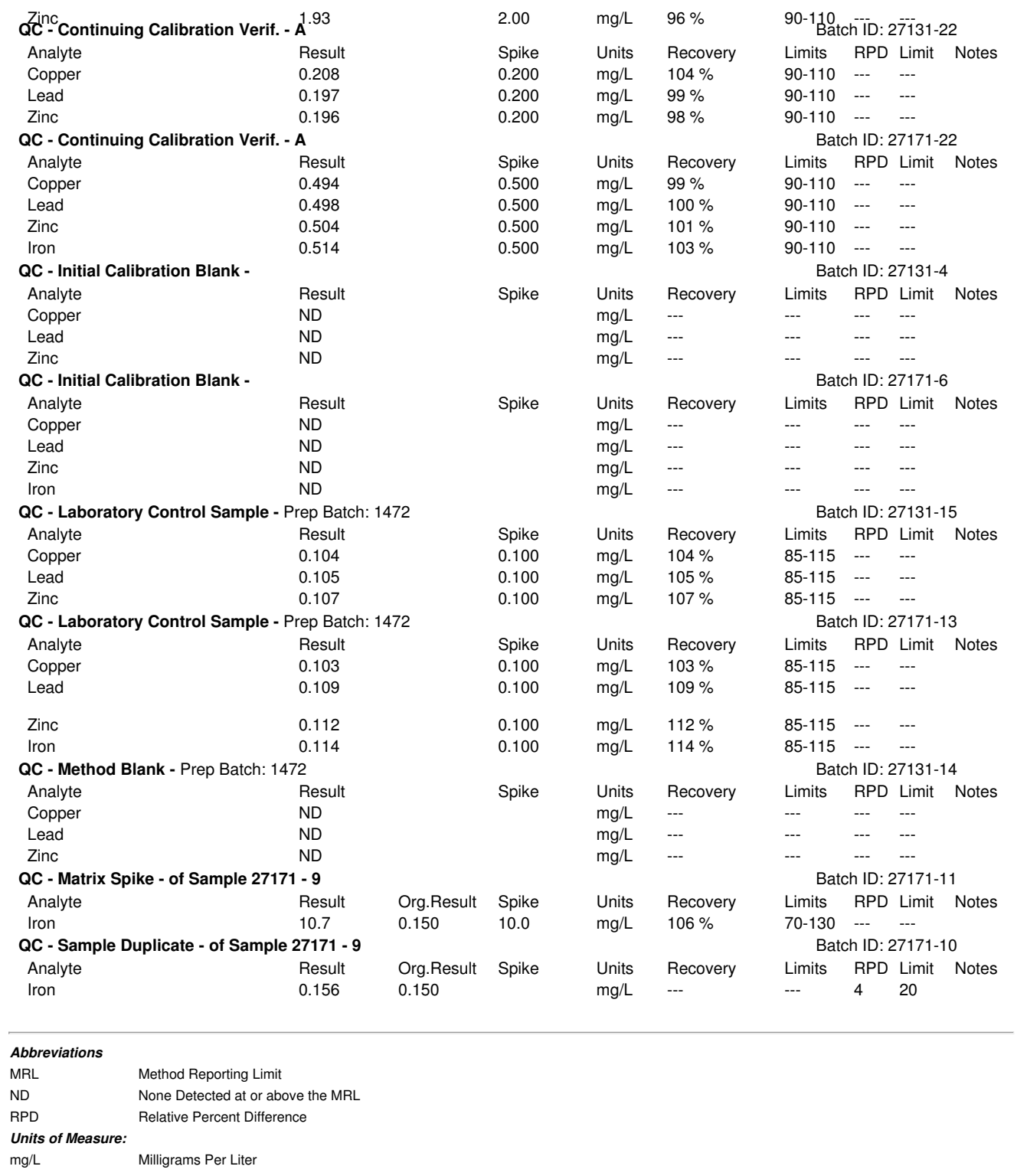


C.12 Lab Report for Stormwater Sample No. 2 (page 6/6)

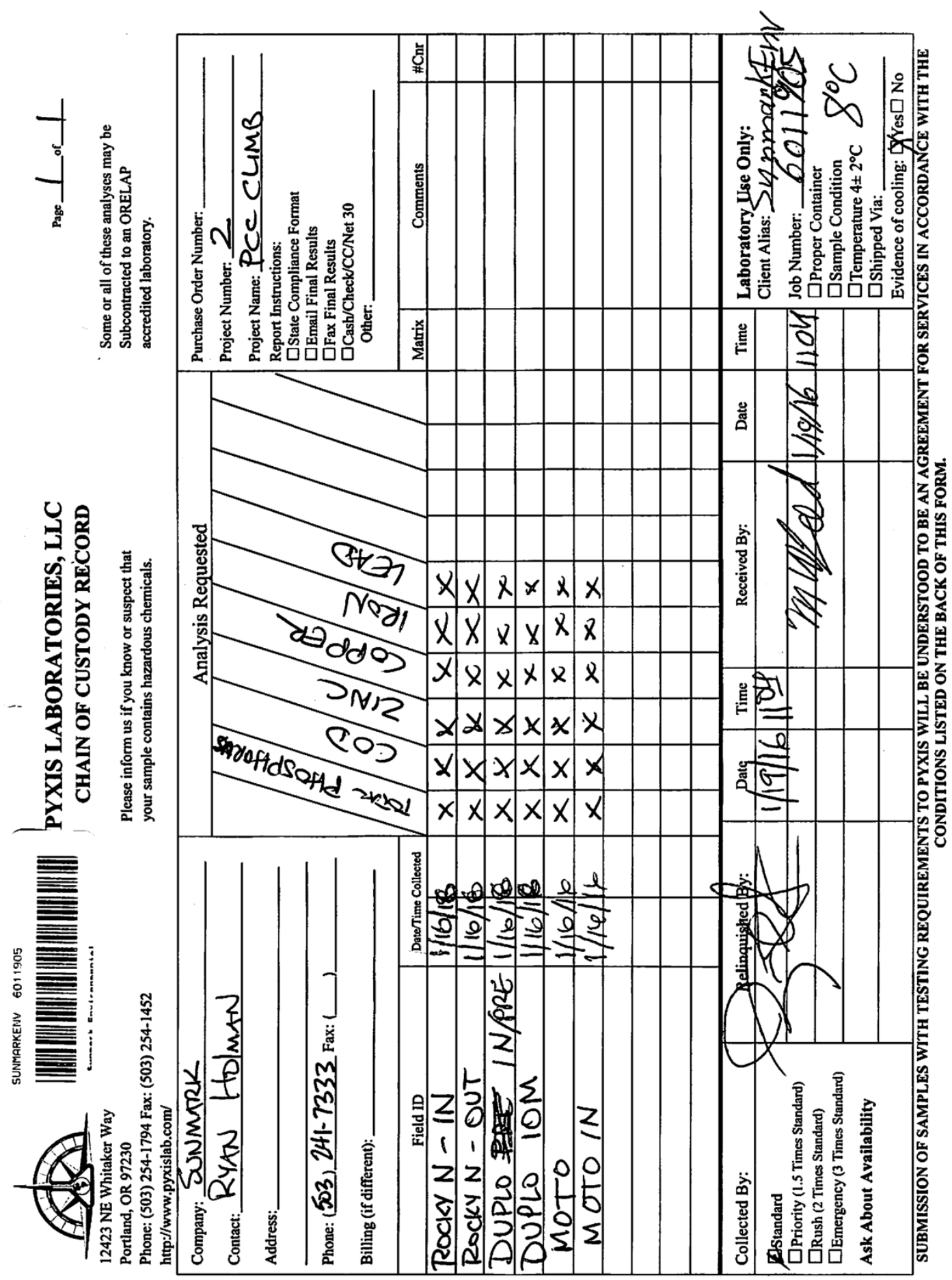


PIXIS Labs

Accurate. Reliable. On Time.

Pixis Labs

12423 NE Whitaker Way

Portland, OR 97230

503-254-1794

Ryan Holman

Sunmark Environmental

PO Box 1210

FAIRVIEW, OR 97024

Dear Ryan Holman,

$\begin{array}{ll}\text { Job Number: } & 6020414 \\ \text { Report Date: } & 02 / 22 / 2016 \\ \text { ORELAP \#: } & \text { OR100028 } \\ \text { Project Name: } & 3 \\ \text { Project No: } & \text { PCC CLIMB }\end{array}$

\section{Cover Letter}

Enclosed please find Pixis Labs analytical report for samples received as order number 6020414 on 02/04/2016. Should you have any questions about this report or any other matter, please do not hesitate to contact us. We are here to help you.

Test results relate only to the parameters tested and to the samples as received by the laboratory. Test results meet all requirements of NELAP and the Pixis quality assurance plan unless otherwise noted. This report shall not be reproduced, except in full, without the written consent of this laboratory. Samples will be kept a maximum of 15 days from the report date unless prior arrangements have been made.

Thank you for allowing Pixis to be of service to you, we appreciate your business.

Sincerely,

Signed

Richard Reid

Project Manager 


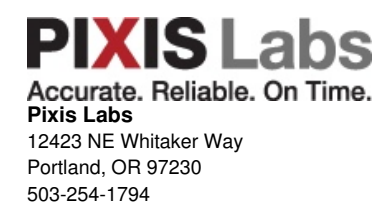

$\begin{array}{ll}\text { Job Number: } & 6020414 \\ \text { Report Date: } & 02 / 22 / 2016 \\ \text { ORELAP \#: } & \text { OR100028 } \\ \text { Project Name: } & 3 \\ \text { Project No: } & \text { PCC CLIMB }\end{array}$

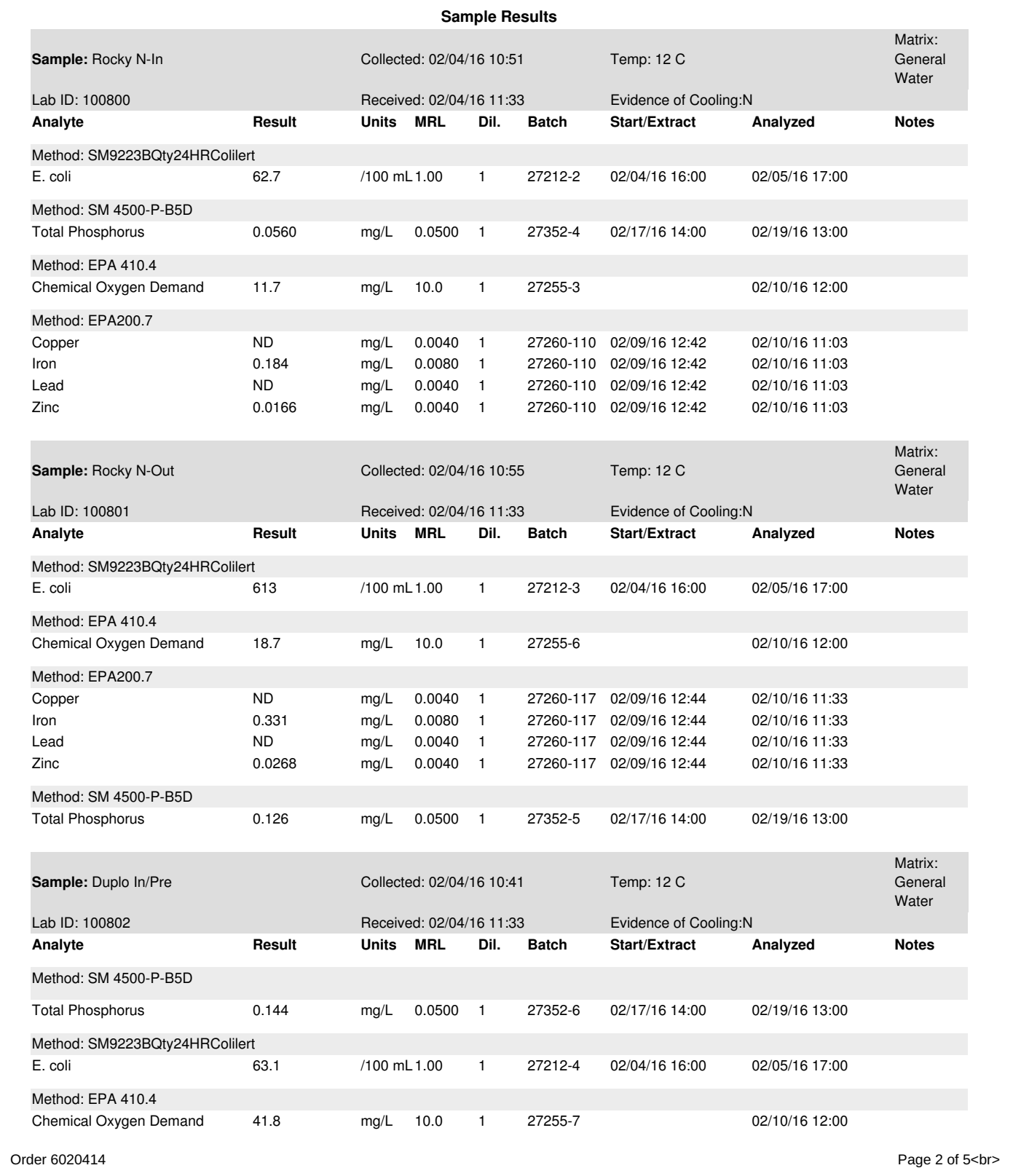


C.15 Lab Report for Stormwater Sample No. 3 (page 3/6)

\begin{tabular}{|c|c|c|c|c|c|c|c|c|}
\hline \multicolumn{9}{|l|}{ Method: EPA200.7 } \\
\hline Copper & 0.0066 & $\mathrm{mg} / \mathrm{L}$ & 0.0040 & 1 & $27260-118$ & 02/09/16 12:44 & 02/10/16 11:36 & \\
\hline Iron & 0.809 & $\mathrm{mg} / \mathrm{L}$ & 0.0080 & 1 & $27260-118$ & 02/09/16 12:44 & 02/10/16 11:36 & \\
\hline Lead & ND & $\mathrm{mg} / \mathrm{L}$ & 0.0040 & 1 & $27260-118$ & 02/09/16 12:44 & 02/10/16 11:36 & \\
\hline Zinc & 0.0349 & $\mathrm{mg} / \mathrm{L}$ & 0.0040 & 1 & $27260-118$ & 02/09/16 12:44 & 02/10/16 11:36 & \\
\hline \multicolumn{2}{|l|}{ Sample: Duplo 10M } & \multicolumn{4}{|c|}{ Collected: 02/04/16 10:49 } & \multicolumn{2}{|l|}{ Temp: $12 \mathrm{C}$} & $\begin{array}{l}\text { Matrix: } \\
\text { General } \\
\text { Water }\end{array}$ \\
\hline \multicolumn{2}{|l|}{ Lab ID: 100803} & \multicolumn{4}{|c|}{ Received: 02/04/16 11:33 } & \multicolumn{2}{|c|}{ Evidence of Cooling: $\mathrm{N}$} & \\
\hline Analyte & Result & Units & MRL & Dil. & Batch & Start/Extract & Analyzed & Notes \\
\hline \multicolumn{9}{|l|}{ Method: SM 4500-P-B5D } \\
\hline Total Phosphorus & ND & $\mathrm{mg} / \mathrm{L}$ & 0.0500 & 1 & $27352-7$ & $02 / 17 / 1614: 00$ & 02/19/16 13:00 & \\
\hline \multicolumn{9}{|c|}{ Method: SM9223BQty24HRColilert } \\
\hline E. coli & 501 & $/ 100 \mathrm{~m}$ & L 1.00 & 1 & $27212-5$ & 02/04/16 16:00 & 02/05/16 17:00 & \\
\hline \multicolumn{9}{|l|}{ Method: EPA 410.4} \\
\hline Chemical Oxygen Demand & ND & $\mathrm{mg} / \mathrm{L}$ & 10.0 & 1 & $27255-8$ & & 02/10/16 12:00 & \\
\hline \multicolumn{9}{|l|}{ Method: EPA200.7 } \\
\hline Copper & ND & $\mathrm{mg} / \mathrm{L}$ & 0.0040 & 1 & $27260-119$ & 02/09/16 12:44 & 02/10/16 11:39 & \\
\hline Iron & 0.0855 & $\mathrm{mg} / \mathrm{L}$ & 0.0080 & 1 & $27260-119$ & 02/09/16 12:44 & 02/10/16 11:39 & \\
\hline Lead & ND & $\mathrm{mg} / \mathrm{L}$ & 0.0040 & 1 & $27260-119$ & 02/09/16 12:44 & 02/10/16 11:39 & \\
\hline Zinc & 0.0095 & $\mathrm{mg} / \mathrm{L}$ & 0.0040 & 1 & $27260-119$ & 02/09/16 12:44 & 02/10/16 11:39 & \\
\hline \multicolumn{2}{|l|}{ Sample: Moto In } & \multicolumn{4}{|c|}{ Collected: 02/04/16 11:02 } & \multicolumn{2}{|l|}{ Temp: $12 \mathrm{C}$} & $\begin{array}{l}\text { Matrix: } \\
\text { General } \\
\text { Water }\end{array}$ \\
\hline \multicolumn{2}{|l|}{ Lab ID: 100804} & \multicolumn{4}{|c|}{ Received: 02/04/16 11:33 } & \multicolumn{2}{|c|}{ Evidence of Cooling: $\mathrm{N}$} & \\
\hline Analyte & Result & Units & MRL & Dil. & Batch & Start/Extract & Analyzed & Notes \\
\hline \multicolumn{9}{|l|}{ Method: SM 4500-P-B5D } \\
\hline Total Phosphorus & 0.0860 & $\mathrm{mg} / \mathrm{L}$ & 0.0500 & 1 & $27352-8$ & 02/17/16 14:00 & 02/19/16 13:00 & \\
\hline \multicolumn{9}{|c|}{ Method: SM9223BQty24HRColilert } \\
\hline E. coli & 48.0 & $/ 100 \mathrm{~m}$ & L 1.00 & 1 & $27212-6$ & $02 / 04 / 1616: 00$ & 02/05/16 17:00 & \\
\hline \multicolumn{9}{|l|}{ Method: EPA 410.4} \\
\hline Chemical Oxygen Demand & 18.7 & $\mathrm{mg} / \mathrm{L}$ & 10.0 & 1 & $27255-9$ & & 02/10/16 12:00 & \\
\hline \multicolumn{9}{|l|}{ Method: EPA200.7 } \\
\hline Copper & ND & $\mathrm{mg} / \mathrm{L}$ & 0.0040 & 1 & $27260-120$ & 02/09/16 12:44 & 02/10/16 11:43 & \\
\hline Iron & 0.623 & $\mathrm{mg} / \mathrm{L}$ & 0.0080 & 1 & $27260-120$ & 02/09/16 12:44 & 02/10/16 11:43 & \\
\hline Lead & ND & $\mathrm{mg} / \mathrm{L}$ & 0.0040 & 1 & $27260-120$ & 02/09/16 12:44 & 02/10/16 11:43 & \\
\hline Zinc & 0.0147 & $\mathrm{mg} / \mathrm{L}$ & 0.0040 & 1 & $27260-120$ & 02/09/16 12:44 & 02/10/16 11:43 & \\
\hline \multicolumn{2}{|l|}{ Sample: Moto Out } & Collec & ed: $02 / 04$ & 1610 & & Temp: $12 \mathrm{C}$ & & $\begin{array}{l}\text { Matrix: } \\
\text { General } \\
\text { Water }\end{array}$ \\
\hline Lab ID: 100805 & & Receiv & ed: $02 / 04$ & $1611:$ & & Evidence of $\mathrm{Coc}$ & & \\
\hline Analyte & Result & Units & MRL & Dil. & Batch & Start/Extract & Analyzed & Notes \\
\hline Method: SM 4500-P-B5D & & & & & & & & \\
\hline Total Phosphorus & 0.226 & $\mathrm{mg} / \mathrm{L}$ & 0.0500 & 1 & $27352-9$ & $02 / 17 / 1614: 00$ & 02/19/16 13:00 & \\
\hline Method: SM9223BQty24HR & & & & & & & & \\
\hline E. coli & 649 & $/ 100 \mathrm{~m}$ & L 1.00 & 1 & $27212-7$ & 02/04/16 16:00 & 02/05/16 17:00 & \\
\hline Method: EPA 410.4 & & & & & & & & \\
\hline Chemical Oxygen Demand & 24.5 & $\mathrm{mg} / \mathrm{L}$ & 10.0 & 1 & $27255-10$ & & 02/10/16 12:00 & \\
\hline Method: EPA200.7 & & & & & & & & \\
\hline Copper & 0.0048 & $\mathrm{mg} / \mathrm{L}$ & 0.0040 & 1 & $27260-121$ & 02/09/16 12:44 & 02/10/16 11:46 & \\
\hline Iron & 0.0728 & $\mathrm{mg} / \mathrm{L}$ & 0.0080 & 1 & $27260-121$ & 02/09/16 12:44 & 02/10/16 11:46 & \\
\hline
\end{tabular}

Order 6020414

Page 3 of $5<b r>$ 
C.16 Lab Report for Stormwater Sample No. 3 (page 4/6)

\begin{tabular}{|c|c|c|c|c|c|c|c|c|c|}
\hline \multirow[t]{2}{*}{$\begin{array}{l}\text { Lead } \\
\text { Zinc }\end{array}$} & \multirow[t]{2}{*}{$\begin{array}{l}\text { ND } \\
0.0632\end{array}$} & \multirow[t]{2}{*}{$\begin{array}{ll}\mathrm{mg} / \mathrm{L} & 0.0040 \\
\mathrm{mg} / \mathrm{L} & 0.0040\end{array}$} & $\begin{array}{l}1 \\
1\end{array}$ & $\begin{array}{l}27260-121 \\
27260-121\end{array}$ & $\begin{array}{l}9 / 16 \text { 12:44 } \\
9 / 1612: 44\end{array}$ & \multicolumn{4}{|c|}{$\begin{array}{l}02 / 10 / 16 \text { 11:46 } \\
02 / 10 / 16 ~ 11: 46\end{array}$} \\
\hline & & & ality Co & Results & & & & & \\
\hline \multicolumn{10}{|l|}{ SM9223BQty24HRColilert } \\
\hline \multicolumn{10}{|l|}{ SM 4500-P-B5D } \\
\hline \multicolumn{6}{|l|}{ QC - Initial Calibration Verif. - } & \multicolumn{4}{|c|}{ Batch ID: 27352-1 } \\
\hline Analyte & Result & & Spike & Units & Recovery & Limits & RPD & Limit & Notes \\
\hline Total Phosphorus & 0.539 & & 0.500 & $\mathrm{mg} / \mathrm{L}$ & $108 \%$ & $90-110$ & --- & --- & \\
\hline \multicolumn{6}{|c|}{ QC - Continuing Calibration Verif. - A } & \multicolumn{4}{|c|}{ Batch ID: $27352-25$} \\
\hline Analyte & Result & & Spike & Units & Recovery & Limits & RPD & Limit & Notes \\
\hline Total Phosphorus & 0.519 & & 0.500 & $\mathrm{mg} / \mathrm{L}$ & $104 \%$ & $90-110$ & --- & --- & \\
\hline \multicolumn{3}{|l|}{ QC - Initial Calibration Blank - } & & & & \multicolumn{4}{|c|}{ Batch ID: $27352-2$} \\
\hline Analyte & Result & & Spike & Units & Recovery & Limits & RPD & Limit & Notes \\
\hline Total Phosphorus & ND & & & $\mathrm{mg} / \mathrm{L}$ & --- & --- & --- & --- & \\
\hline \multicolumn{6}{|c|}{ QC - Matrix Spike - of Sample 27352 - 10} & Bat & ch ID: 2 & $27352-1$ & \\
\hline Analyte & Result & Org.Result & Spike & Units & Recovery & Limits & RPD & Limit & Notes \\
\hline Total Phosphorus & 1.18 & 0.0460 & 1.00 & $\mathrm{mg} / \mathrm{L}$ & $113 \%$ & $80-120$ & --- & --- & \\
\hline QC - Matrix Spike Duplicate - & of Sample 273 & $52-10$ & & & & Bat & ch ID: 2 & $27352-1$ & \\
\hline Analyte & Result & Org.Result & Spike & Units & Recovery & Limits & RPD & Limit & Notes \\
\hline Total Phosphorus & 1.14 & 0.0460 & 1.00 & $\mathrm{mg} / \mathrm{L}$ & $110 \%$ & $80-120$ & 3 & 20 & \\
\hline EPA 410.4 & & & & & & & & & \\
\hline QC - Initial Calibration Verif. - & & & & & & Bat & ch ID: 2 & $27255-2$ & \\
\hline Analyte & Result & & Spike & Units & Recovery & Limits & RPD & Limit & Notes \\
\hline Chemical Oxygen Demand & 67.9 & & 75.0 & $\mathrm{mg} / \mathrm{L}$ & $91 \%$ & $90-110$ & --- & --- & \\
\hline QC - Continuing Calibration V & lerif. - A & & & & & Bat & ch ID: 2 & $27255-1$ & \\
\hline Analyte & Result & & Spike & Units & Recovery & Limits & RPD & Limit & Notes \\
\hline Chemical Oxygen Demand & 70.4 & & 75.0 & $\mathrm{mg} / \mathrm{L}$ & $94 \%$ & $90-110$ & --- & --- & \\
\hline QC - Initial Calibration Blank - & & & & & & Bat & ch ID: 2 & $27255-1$ & \\
\hline Analyte & Result & & Spike & Units & Recovery & Limits & RPD & Limit & Notes \\
\hline Chemical Oxygen Demand & ND & & & $\mathrm{mg} / \mathrm{L}$ & --- & --- & --- & -- & \\
\hline QC - Matrix Spike - of Sample & $27255-3$ & & & & & Bat & ch ID: 2 & $27255-4$ & \\
\hline Analyte & Result & Org.Result & Spike & Units & Recovery & Limits & RPD & Limit & Notes \\
\hline Chemical Oxygen Demand & 83.1 & 11.7 & 75.0 & $\mathrm{mg} / \mathrm{L}$ & $95 \%$ & $80-120$ & -- & --- & \\
\hline QC - Matrix Spike Duplicate - C & of Sample 27 & $55-3$ & & & & Bat & ch ID: 2 & $27255-5$ & \\
\hline Analyte & Result & Org.Result & Spike & Units & Recovery & Limits & RPD & Limit & Notes \\
\hline Chemical Oxygen Demand & 86.0 & 11.7 & 75.0 & $\mathrm{mg} / \mathrm{L}$ & $99 \%$ & $80-120$ & 3 & 20 & \\
\hline EPA200.7 & & & & & & & & & \\
\hline QC - Initial Calibration Verif. - & & & & & & Bat & ch ID: 2 & $27260-1$ & \\
\hline Analyte & Result & & Spike & Units & Recovery & Limits & RPD & Limit & Notes \\
\hline Copper & 0.102 & & 0.100 & $\mathrm{mg} / \mathrm{L}$ & $102 \%$ & $95-105$ & -- & --- & \\
\hline Lead & 0.104 & & 0.100 & $\mathrm{mg} / \mathrm{L}$ & $104 \%$ & $95-105$ & --- & --- & \\
\hline Zinc & 0.102 & & 0.100 & $\mathrm{mg} / \mathrm{L}$ & $102 \%$ & $95-105$ & --- & --- & \\
\hline QC - Continuing Calibration B & Blank - B & & & & & Bat & ch ID: 2 & $27260-1$ & 101 \\
\hline Analyte & Result & & Spike & Units & Recovery & Limits & RPD & Limit & Notes \\
\hline Copper & ND & & & $\mathrm{mg} / \mathrm{L}$ & --- & --- & --- & --- & \\
\hline Iron & ND & & & $\mathrm{mg} / \mathrm{L}$ & --- & --- & --- & --- & \\
\hline Lead & ND & & & $\mathrm{mg} / \mathrm{L}$ & --- & --- & --- & --- & \\
\hline Zinc & ND & & & $\mathrm{mg} / \mathrm{L}$ & --- & --- & --- & --- & \\
\hline QC - Continuing Calibration V & erif. - B & & & & & Bat & ch ID: 2 & $27260-1$ & 100 \\
\hline Analyte & Result & & Spike & Units & Recovery & Limits & RPD & Limit & Notes \\
\hline Copper & 0.512 & & 0.500 & $\mathrm{mg} / \mathrm{L}$ & $102 \%$ & $90-110$ & --- & --- & \\
\hline Iron & 0.528 & & 0.500 & $\mathrm{mg} / \mathrm{L}$ & $106 \%$ & $90-110$ & --- & --- & \\
\hline Lead & 0.511 & & 0.500 & $\mathrm{mg} / \mathrm{L}$ & $102 \%$ & $90-110$ & --- & --- & \\
\hline Zinc & 0.521 & & 0.500 & $\mathrm{mg} / \mathrm{L}$ & $104 \%$ & $90-110$ & --- & --- & \\
\hline QC - Initial Calibration Blank - & & & & & & Bat & ch ID: 2 & $27260-5$ & \\
\hline Analyte & Result & & Spike & Units & Recovery & Limits & RPD & Limit & Notes \\
\hline Copper & ND & & & $\mathrm{mg} / \mathrm{L}$ & --- & --- & & --- & \\
\hline Iron & ND & & & $\mathrm{mg} / \mathrm{L}$ & --- & --- & --- & --- & \\
\hline Lead & ND & & & $\mathrm{mg} / \mathrm{L}$ & --- & --- & --- & --- & \\
\hline
\end{tabular}


C.17 Lab Report for Stormwater Sample No. 3 (page 5/6)

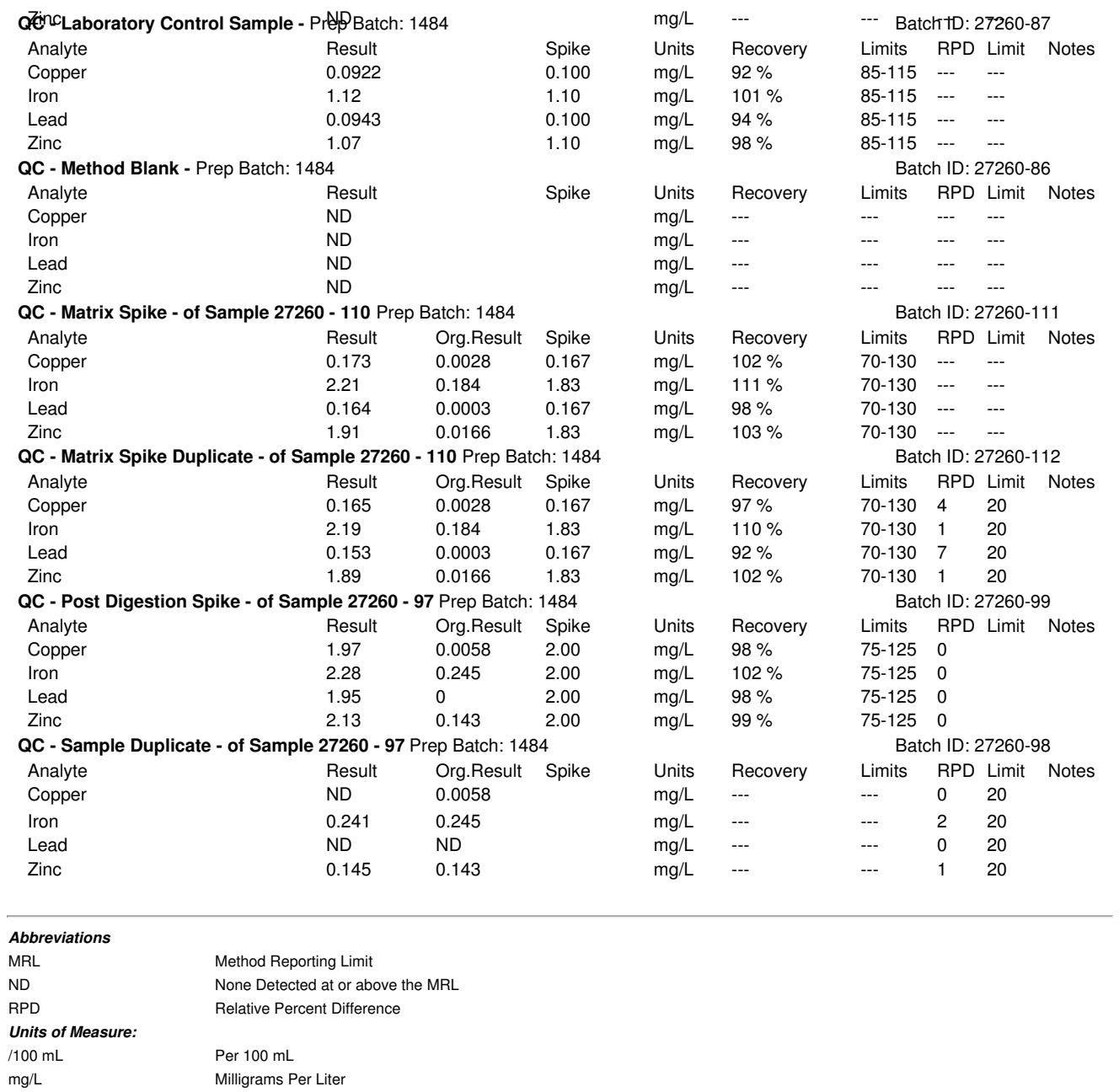


C.18 Lab Report for Stormwater Sample No. 3 (page 6/6)

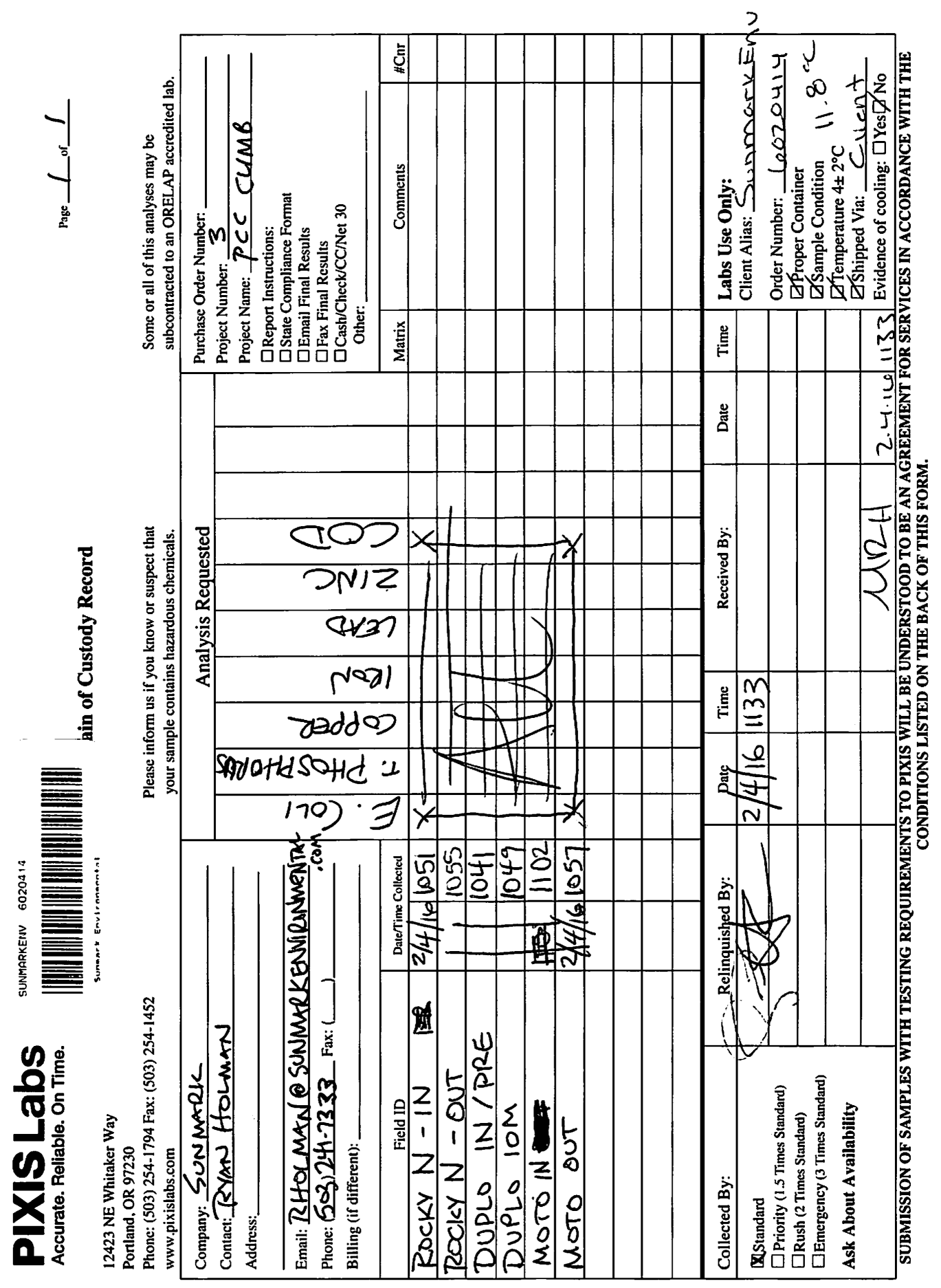

